This document was prepared in conjunction with work accomplished under Contract No. DE-AC09-96SR18500 with the U. S. Department of Energy.

\title{
DISCLAIMER
}

This report was prepared as an account of work sponsored by an agency of the United States Government. Neither the United States Government nor any agency thereof, nor any of their employees, nor any of their contractors, subcontractors or their employees, makes any warranty, express or implied, or assumes any legal liability or responsibility for the accuracy, completeness, or any third party's use or the results of such use of any information, apparatus, product, or process disclosed, or represents that its use would not infringe privately owned rights. Reference herein to any specific commercial product, process, or service by trade name, trademark, manufacturer, or otherwise, does not necessarily constitute or imply its endorsement, recommendation, or favoring by the United States Government or any agency thereof or its contractors or subcontractors. The views and opinions of authors expressed herein do not necessarily state or reflect those of the United States Government or any agency thereof. 


\section{DWPF RECYCLE EVAPORATOR SIMULANT TESTS}

M. E. Stone

April 2005

Immobilization Technology Section Savannah River National Laboratory Aiken, SC 29808 


\title{
DISCLAIMER
}

This report was prepared by Westinghouse Savannah River Company (WSRC) for the United States Department of Energy under Contract No. DE-AC09-96SR18500 and is an account of work performed under that contract. Neither the United States Department of Energy, nor WSRC, nor any of their employees makes any warranty, expressed or implied, or assumes any legal liability or responsibility for the accuracy, completeness, or usefulness, of any information, apparatus, or product or process disclosed herein or represents that its use will not infringe privately owned rights. Reference herein to any specific commercial product, process, or service by trademark, name, manufacturer or otherwise does not necessarily constitute or imply endorsement, recommendation, or favoring of same by WSRC or by the United States Government or any agency thereof. The views and opinions of the authors expressed herein do not necessarily state or reflect those of the United States Government or any agency thereof.

\author{
Printed in the United States of America \\ Prepared For \\ U.S. Department of Energy
}


Key Words: DWPF, Recycle,

Evaporation, Antifoam

\author{
Retention: Permanent
}

\title{
DWPF RECYCLE EVAPORATOR SIMULANT TESTS
}

M. E. Stone

April 2005

Immobilization Technology Section Savannah River National Laboratory Aiken, SC 29808 
WSRC-TR-2005-00142

Revision 0

\section{REVIEWS AND APPROVALS}

\section{AUTHOR(S):}

MIE fl

$4 / 21 / 05$

M. E. Stone, Immobilization Technology Section

Date

\section{TECHNICAL REVIEWERS:}

TrQ

$4-21-05$

W. E. Daniel, Immobilization Technology Section

Date

Ceni<smiles></smiles>

T. L. Fellinger, Immobilization Technology Section

$\frac{4-25-2005}{\text { Date }}$

\section{APPROVERS}

Evttretrphutev

E. W. Holtzscheiter, Manager, Immobilization Technology Section

$$
\text { Sfroma }
$$

S. L. Marra, Manager, Glass Formulation \& Process Development

W.B. Van Pelt

W. B. Van Pelt, Manager, DWPF Programs Engineering
$4 / 25 / 05$

Date

$4 / 25105$

Date

$4-27-05$ 


\section{EXECUTIVE SUMMARY}

Testing was performed to determine the feasibility and processing characteristics of an evaporation process to reduce the volume of the recycle stream from the Defense Waste Processing Facility (DWPF). The concentrated recycle would be returned to DWPF while the overhead condensate would be transferred to the Effluent Treatment Plant.

Various blends of evaporator feed were tested using simulants developed from characterization of actual recycle streams from DWPF and input from DWPF-Engineering. The simulated feed was evaporated in laboratory scale apparatus to target a $30 \mathrm{X}$ volume reduction. Condensate and concentrate samples from each run were analyzed and the process characteristics (foaming, scaling, etc) were visually monitored during each run.

The following conclusions were made from the testing:

Concentration of the "typical" recycle stream in DWPF by 30X was feasible. The addition of DWTT recycle streams to the typical recycle stream raises the solids content of the evaporator feed considerably and lowers the amount of concentration that can be achieved.

Foaming was noted during all evaporation tests and must be addressed prior to operation of the fullscale evaporator. Tests were conducted that identified Dow Corning 2210 as an antifoam candidate that warrants further evaluation.

The condensate has the potential to exceed the ETP WAC for mercury, silicon, and TOC. Controlling the amount of equipment decontamination recycle in the evaporator blend would help meet the TOC limits. The evaporator condensate will be saturated with mercury and elemental mercury will collect in the evaporator condensate collection vessel.

No scaling on heating surfaces was noted during the tests, but splatter onto the walls of the evaporation vessels led to a buildup of solids. These solids were difficult to remove with $2 \mathrm{M}$ nitric acid. Precipitation of solids was not noted during the testing.

Some of the aluminum present in the recycle streams was converted from gibbsite to aluminum oxide during the evaporation process.

The following recommendations were made:

Recycle from the DWTT should be metered in slowly to the "typical" recycle streams to avoid spikes in solids content to allow consistent processing and avoid process upsets. Additional studies should be conducted to determine acceptable volume ratios for the HEME dissolution and decontamination solutions in the evaporator feed.

Dow Corning 2210 antifoam should be evaluated for use to control foaming. Additional tests are required to determine the concentration of antifoam required to prevent foaming during startup, the frequency of antifoam additions required to control foaming during steady state processing, and the ability of the antifoam to control foam over a range of potential feed compositions. This evaluation should also include evaluation of the degradation of the antifoam and impact on the silicon and TOC content of the condensate. 
The caustic HEME dissolution recycle stream should be neutralized to at least $\mathrm{pH}$ of 7 prior to blending with the acidic recycle streams.

Dow Corning 2210 should be used during the evaporation testing using the radioactive recycle samples received from DWPF.

Evaluation of additional antifoam candidates should be conducted as a backup for Dow Corning 2210.

A camera and/or foam detection instrument should be included in the evaporator design to allow monitoring of the foaming behavior during operation.

The potential for foam formation and high solids content should be considered during the design of the evaporator vessel. 


\section{TABLE OF CONTENTS}

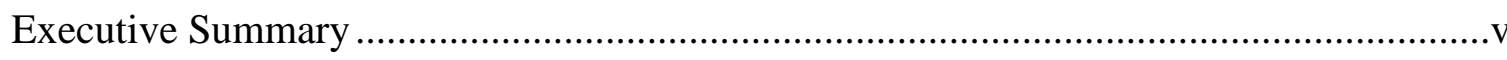

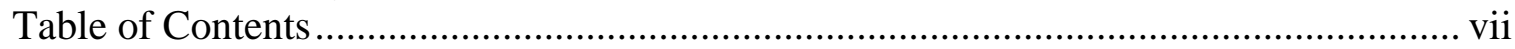

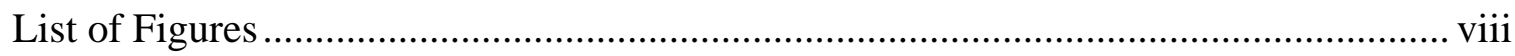

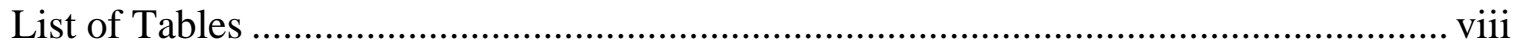

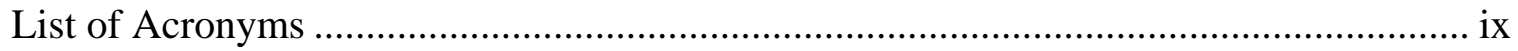

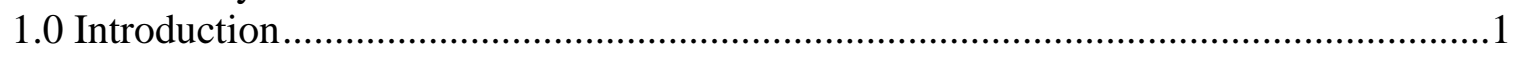

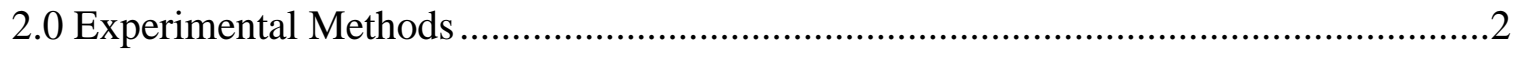

2.1 Recycle Evaporator Feed Blending ..............................................................

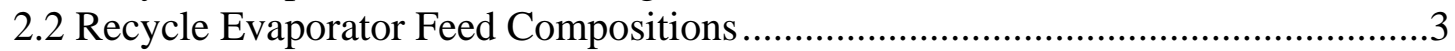

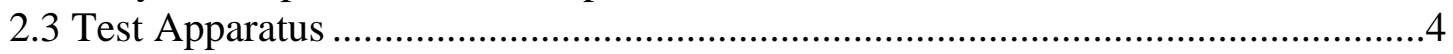

2.4 Run Performance .....................................................................................

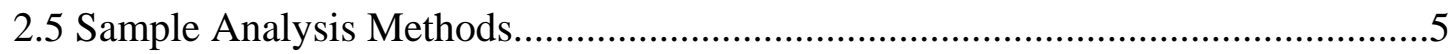

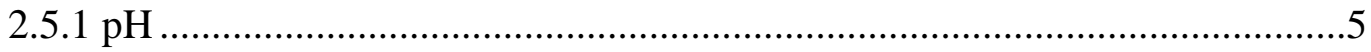

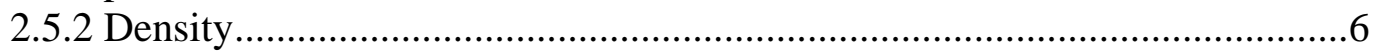

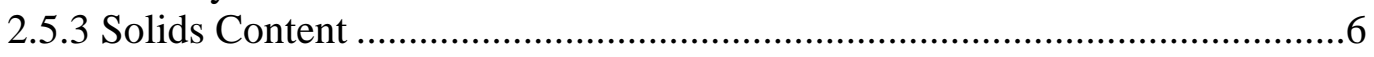

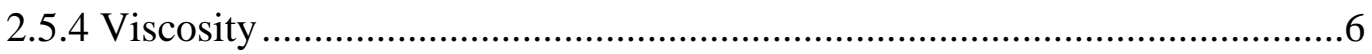

2.5.5 Mobile Laboratory Measurements .............................................................6

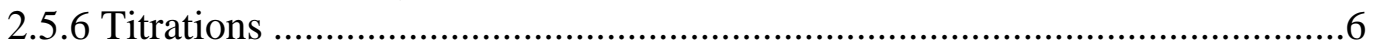

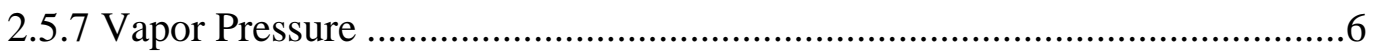

2.5.8 ADS Measurements.............................................................................

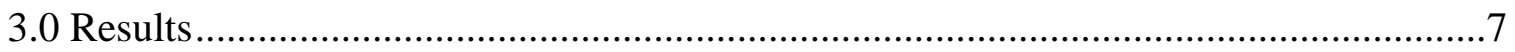

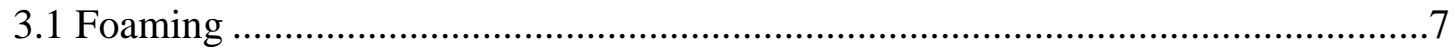

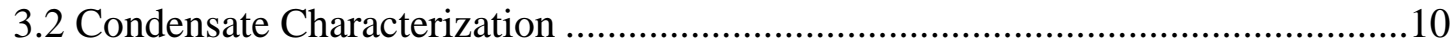

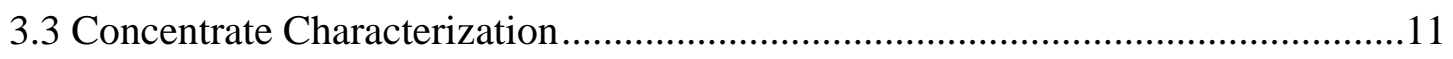

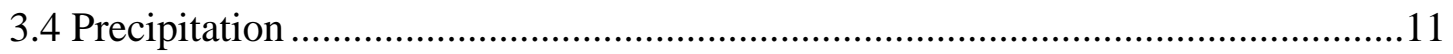

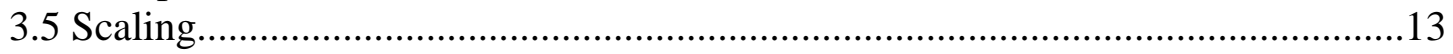

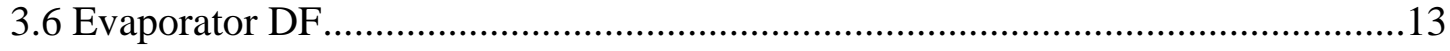

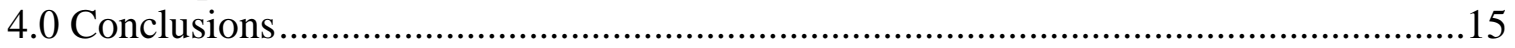

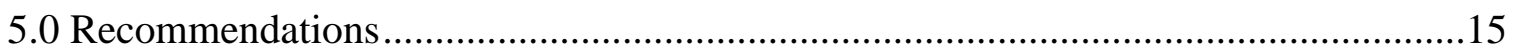

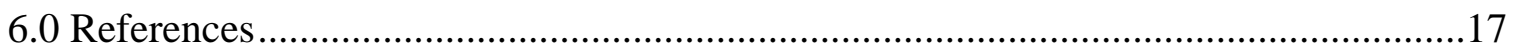

Appendix A. Simulant Recipes ..........................................................................18

Appendix B. Equipment Diagrams and Operation Steps............................................20

Appendix C. Sample Results from Boil-Down Tests ....................................................26

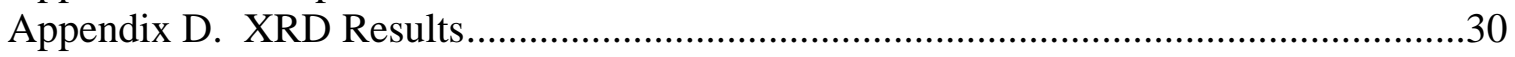

Appendix E. Condensate $\mathrm{pH}$ Profiles .................................................................40

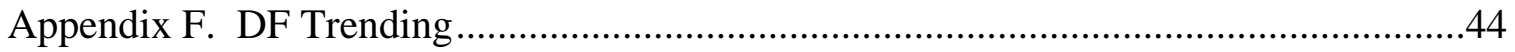




\section{LIST OF FIGURES}

Figure 1. Foaming during Initial and Final Stages of Scenario 1, Run 1 Evaporation............ 7

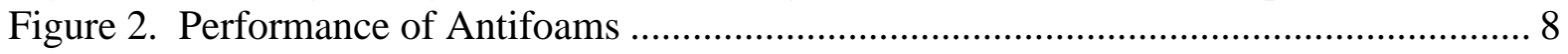

Figure 3. Flocculation during Addition of DSP Antifoam .............................................. 9

Figure 4: Foaming During Antifoam Tests with DSP and After 2210 Addition.................. 10

Figure 5. XRD from Scenario 1 Feed Sample ............................................................ 12

Figure 6. XRD from Scenario 1 Concentrate Sample....................................................... 12

Figure 7: Scale Buildup on Walls during Scenario 1-1 ................................................... 13

Figure 8. DF for Potassium and Molybdenum............................................................... 14

\section{LIST OF TABLES}

Table 1. Simulant Compositions and Physical Properties ................................................ 4

Table 2. Scaling Parameters...................................................................................... 5

Table 3. Major Species in Recycle Evaporator Condensate ............................................. 10

Table 4. Evaporator DF for Selected Species ................................................................... 14 


\section{LIST OF ACRONYMS}

$\begin{array}{ll}\text { DWPF } & \text { Defense Waste Processing Facility } \\ \text { SMECT } & \text { Slurry Mix Evaporator Condensate Tank } \\ \text { OGCT } & \text { Off Gas Condensate Tank } \\ \text { DWTT } & \text { Decontamination Waste Treatment Tank } \\ \text { RCT } & \text { Recycle Collection Tank } \\ \text { SRAT } & \text { Sludge Receipt and Adjustment Tank } \\ \text { ETP } & \text { Effluent Treatment Plant } \\ \text { SRNL } & \text { Savannah River National Laboratory } \\ \text { ITS } & \text { Immobilization Technology Section } \\ \text { ACTL } & \text { Aiken County Technology Laboratory } \\ \text { ML } & \text { Mobile Lab } \\ \text { ADS } & \text { Analytical Development Section } \\ \text { DWPF-E } & \text { Defense Waste Processing Facility: Engineering } \\ \text { WWCT } & \text { Waste Water Collection Tank }\end{array}$




\subsection{INTRODUCTION}

DWPF converts the high level waste slurries stored at the Savannah River Site into borosilicate glass for long-term storage. The vitrification process results in the generation of approximately five gallons of dilute recycle streams for each gallon of waste slurry vitrified. This dilute recycle stream is currently transferred to the H-area Tank Farm and amounts to approximately 1,400,000 gallons of effluent per year. Process changes to incorporate salt waste could increase the amount of effluent to approximately 2,900,000 gallons per year.

The recycle consists of two major streams and four smaller streams. The first recycle major recycle stream is condensate from the Chemical Process Cell, and is collected in the Slurry Mix Evaporator Condensate Tank (SMECT). The second major recycle stream is the melter offgas condensate which is collected in the Off Gas Condensate Tank (OGCT). The four smaller streams are the sample flushes, sump flushes, Decon solution, and HEME dissolution solution. These streams are collected in the Decontamination Waste Treatment Tank (DWTT) or the Recycle Collection Tank (RCT). All recycle streams are combined in the RCT and treated with sodium nitrite and sodium hydroxide prior to transfer to the tank farm.

Tank Farm space limitations and previous outages in the $2 \mathrm{H}$ Evaporator system due to deposition of sodium alumina-silicates ${ }^{1}$ have led to evaluation of alternative methods of dealing with the DWPF recycle. One option identified for processing the recycle was a dedicated evaporator to concentrate the recycle stream to allow the solids to be recycled to the DWPF Sludge Receipt and Adjustment Tank (SRAT) and the condensate to be treated in the Effluent Treatment Plant (ETP).

In order to meet process objectives, the recycle stream must be concentrated to $1 / 30^{\text {th }}$ of the feed volume during the evaporation process. The concentrated stream must be pumpable to the DWPF SRAT vessel and should not precipitate solids to avoid fouling the evaporator vessel and heat transfer coils. The evaporation process must not generate excessive foam and must have a high DF for many species in the evaporator feed to allow the condensate to be transferred to the ETP. An initial scoping study was completed in 2001 to evaluate the feasibility of the evaporator ${ }^{2}$ which concluded that the concentration objectives could be met. This initial study was based on initial estimates of recycle concentration and was based solely on OLI modeling of the evaporation process.

SRNL has completed additional studies using simulated recycle streams to evaluate foaming, scaling, and DF using small-scale laboratory simulations of the evaporator. These studies will also be utilized to validate the results from OLI modeling to gain confidence in using the models to further evaluate the evaporator process. This work was in accordance with guidance from DWPF-E ${ }^{3}$ and was performed in accordance with the Technical Task and Quality Assurance Plan ${ }^{4}$. 


\subsection{EXPERIMENTAL METHODS}

\subsection{Recycle Evaporator Feed Blending}

The recycle evaporator receives feed from multiple sources and the variation in feed composition from the different combinations of streams that could be processed is large. Six scenarios were developed based on input from DWPF Engineering ${ }^{5}$ and were designed to represent various operating conditions of the DWPF process. The recycle volumes shown below are the volume ratios for each of the six scenarios tested. Volumes were based on the recycle volumes utilized during the initial feasibility study. Scenario 1 was evaluated in three separate runs to determine the reproducibility of the results. Addition of a silicon reactant was not performed during the testing.

$\begin{array}{lrc}\text { Scenario 1: Normal Operation with Sludge (Current Process) } \\ & 2016 & \mathrm{ml} \\ \text { SMECT Volume } & 1721 & \mathrm{ml} \\ \text { OGCT Volume } & 5 & \mathrm{ml} \\ \text { Sample Flush Volume } & 258 & \mathrm{ml} \\ \text { Drains/Cells Sump Volume } & 0 & \mathrm{ml} \\ \text { Decon Solution Volume } & 0 & \mathrm{ml}\end{array}$

Scenario 2: CPC Operation with Sludge w/ Melter in Idle

$\begin{array}{lrc}\text { SMECT Volume } & 3539 & \mathrm{ml} \\ \text { OGCT Volume } & 0 & \mathrm{ml} \\ \text { Sample Flush Volume } & 8 & \mathrm{ml} \\ \text { Drains/Cells Sump Volume } & 453 & \mathrm{ml} \\ \text { Decon Solution Volume } & 0 & \mathrm{ml} \\ \text { HEME Dissolution Volume } & 0 & \mathrm{ml} \\ & & \\ \text { Scenario 3: Melter Operation with Sludge w/ CPC Idled } \\ \text { SMECT Volume } & 0 & \mathrm{ml} \\ \text { OGCT Volume } & 4000 & \mathrm{ml} \\ \text { Sample Flush Volume } & 0 & \mathrm{ml} \\ \text { Sump Flush Volume } & 0 & \mathrm{ml} \\ \text { Decon Solution Volume } & 0 & \mathrm{ml} \\ \text { HEME Dissolution Volume } & 0 & \mathrm{ml}\end{array}$

Scenario 4: Normal Operation with Sludge w/ HEME Dissolution

$\begin{array}{lrc}\text { SMECT Volume } & 1452 & \mathrm{ml} \\ \text { OGCT Volume } & 1240 & \mathrm{ml} \\ \text { Sample Flush Volume } & 3 & \mathrm{ml} \\ \text { Drains/Cells Sump Volume } & 0 & \mathrm{ml} \\ \text { Decon Solution Volume } & 0 & \mathrm{ml} \\ \text { HEME Dissolution Volume* } & 1305 & \mathrm{ml}\end{array}$

* The HEME material was neutralized to $\mathrm{pH}=7$ with nitric acid. 
Scenario 5: Decon Operation with Sludge w/ Melter Operating

SMECT Volume

OGCT Volume

Sample Flush Volume

Drains/Cells Sump Volume

Decon Solution Volume

HEME Dissolution Volume

$\begin{array}{rc}0 & \mathrm{ml} \\ 2000 & \mathrm{ml} \\ 0 & \mathrm{ml} \\ 0 & \mathrm{ml} \\ 2000 & \mathrm{ml} \\ 0 & \mathrm{ml}\end{array}$

In addition the five scenarios listed above, the impact of additional condensate generation from the introduction of dilute streams from the planned salt processing was evaluated for normal operation conditions. Scenario 6 was the same as Scenario 1, except that $4000 \mathrm{ml}$ of additional water was added and the required concentration factor for this scenario was $60 \mathrm{X}$, as shown below:

Scenario 6: Normal Operation with Salt Processing Streams

SMECT Volume

OGCT Volume

Sample Flush Volume

Drains/Cells Sump Volume

Decon Solution Volume

HEME Dissolution Volume

Additional water from Salt Streams
$2016 \mathrm{ml}$

$1721 \mathrm{ml}$

$5 \mathrm{ml}$

$258 \mathrm{ml}$

$0 \mathrm{ml}$

$0 \mathrm{ml}$

$4000 \mathrm{ml}$

\subsection{Recycle Evaporator Feed Compositions}

A recipe for each of the streams listed above was developed based on sample results from characterization of DWPF samples ${ }^{6,7}$ or process knowledge ${ }^{8,9}$. These recipes were developed by SRNL and reviewed by DWPF-E ${ }^{10}$. The recipe for each recycle stream is shown in Appendix A. Sample results were obtained from each of the simulants and are shown in Table 1. 
Table 1. Simulant Compositions and Physical Properties

\begin{tabular}{|c|c|c|c|c|c|c|c|c|c|c|c|c|}
\hline Simulant & $\mathrm{Ag}$ & $\mathrm{Al}$ & $\mathrm{B}$ & $\mathrm{Ba}$ & $\mathrm{Ca}$ & $\mathrm{Cr}$ & $\mathrm{Cu}$ & $\mathrm{Fe}$ & $\mathrm{Gd}$ & $\mathrm{Hg}$ & $\mathrm{K}$ & $\mathrm{Li}$ \\
\hline & $\mathrm{mg} / \mathrm{L}$ & $\mathrm{mg} / \mathrm{L}$ & $\mathrm{mg} / \mathrm{L}$ & $\mathrm{mg} / \mathrm{L}$ & $\mathrm{mg} / \mathrm{L}$ & $\mathrm{mg} / \mathrm{L}$ & $\mathrm{mg} / \mathrm{L}$ & $\mathrm{mg} / \mathrm{L}$ & $\mathrm{mg} / \mathrm{L}$ & $\mathrm{mg} / \mathrm{kg}$ & $\mathrm{mg} / \mathrm{L}$ & $\mathrm{mg} / \mathrm{L}$ \\
\hline SMECT & ltd & 0.439 & 0.215 & ltd & 0.069 & ltd & ltd & ltd & ltd & 173 & 0.234 & ltd \\
\hline OGCT & 2.26 & 555 & 7.27 & 10.8 & 307.5 & 2.72 & 17.6 & 2115 & 8.785 & 119 & 26.65 & 18.15 \\
\hline $\begin{array}{l}\text { DWTT } \\
\text { Decon }\end{array}$ & ltd & 0.43 & 1.97 & ltd & 24.1 & ltd & ltd & 1465 & ltd & 187 & 2.08 & ltd \\
\hline $\begin{array}{l}\text { DWTT } \\
\text { HEME }\end{array}$ & ltd & 147 & 293 & 0.256 & 250.5 & 1.415 & ltd & 2.825 & ltd & ltd & 115 & ltd \\
\hline Sample Flush & 16.9 & 15050 & 30.0 & 71.5 & 2115 & 27.95 & 151 & 59200 & 64.5 & $\mathrm{~nm}$ & 217.5 & 46.85 \\
\hline Simulant & $\mathrm{Mg}$ & $\mathrm{Mn}$ & $\mathrm{Na}$ & $\mathrm{Ni}$ & $\mathrm{P}$ & $\mathrm{Pb}$ & $S$ & $\mathrm{Si}$ & $\mathrm{Sr}$ & $\mathrm{Ti}$ & $\mathrm{Zn}$ & $\mathrm{Zr}$ \\
\hline & $\mathrm{mg} / \mathrm{L}$ & $\mathrm{mg} / \mathrm{L}$ & $\mathrm{mg} / \mathrm{L}$ & $\overline{\mathrm{mg} / \mathrm{L}}$ & $\overline{\mathrm{mg} / \mathrm{L}}$ & $\mathrm{mg} / \mathrm{L}$ & $\mathrm{mg} / \mathrm{L}$ & $\mathrm{mg} / \mathrm{L}$ & $\mathrm{mg} / \mathrm{L}$ & $\mathrm{mg} / \mathrm{L}$ & $\mathrm{mg} / \mathrm{L}$ & $\mathrm{mg} / \mathrm{L}$ \\
\hline SMECT & ltd & ltd & 0.494 & ltd & ltd & ltd & ltd & 1705 & ltd & ltd & ltd & ltd \\
\hline OGCT & 383.5 & 631 & 2315 & 93.7 & 6.1 & 9.865 & 41.6 & 40.1 & 1.135 & 1.515 & 29.7 & 4.64 \\
\hline $\begin{array}{l}\text { DWTT } \\
\text { Decon }\end{array}$ & 57.05 & 127 & 197.5 & 42.45 & ltd & ltd & 20.2 & 4.005 & ltd & ltd & ltd & ltd \\
\hline $\begin{array}{l}\text { DWTT } \\
\text { HEME }\end{array}$ & 72.3 & ltd & 30200 & 0.0235 & 0.3995 & 0.203 & 1.83 & 3550 & ltd & 1.02 & 0.073 & 2.43 \\
\hline Sample Flush & 5015 & 9595 & 15100 & 2100 & 78.7 & 78.05 & 487 & 115.5 & 4.235 & 21.75 & 313 & 39.1 \\
\hline Simulant & $\mathrm{NO}_{2}$ & $\mathrm{NO}_{3}$ & $\mathrm{SO}_{4}$ & $\mathrm{HCO}_{2}$ & \multicolumn{2}{|c|}{ Density } & \multicolumn{3}{|c|}{ Solids } & $\mathrm{pH}$ & Acid & Viscosity \\
\hline & & & & & Slurry & Supernate & Total & Soluble & Insoluble & & & \\
\hline & $\mathrm{mg} / \mathrm{L}$ & $\mathrm{mg} / \mathrm{L}$ & $\mathrm{mg} / \mathrm{L}$ & $\mathrm{mg} / \mathrm{L}$ & $\mathrm{g} / \mathrm{ml}$ & $\mathrm{g} / \mathrm{ml}$ & $\mathrm{wt} \%$ & $\mathrm{wt} \%$ & wt\% & & Molar & cP \\
\hline SMECT & ltd & 5930 & ltd & 442.5 & $\mathrm{~nm}$ & 1.0009 & ltd & ltd & ltd & 0.98 & $\mathrm{~nm}$ & $\mathrm{~nm}$ \\
\hline OGCT & ltd & 1595 & 1018.5 & ltd & 1.0010 & 0.9995 & 0.37 & 0.09 & 0.28 & 2.15 & 0.01 & 0.892 \\
\hline $\begin{array}{l}\text { DWTT } \\
\text { Decon }\end{array}$ & ltd & 13650 & 789 & 8385 & 1.0140 & 1.0108 & 2.46 & 1.57 & 0.89 & 1.68 & 0.14 & 0.921 \\
\hline $\begin{array}{l}\text { DWTT } \\
\text { HEME }\end{array}$ & 201.5 & ltd & ltd & ltd & 1.0631 & 1.0613 & 6.35 & 6.35 & 0 & 13.73 & 1.39 & 1.23 \\
\hline Sample Flush & ltd & 39550 & 7575 & 82100 & 1.2886 & $\mathrm{~nm}$ & 38.22 & $\mathrm{~nm}$ & $\mathrm{~nm}$ & 5 & $\mathrm{~nm}$ & $\mathrm{~nm}$ \\
\hline
\end{tabular}

Notes: The DWTT HEME solution was sampled prior to neutralization of the $\mathrm{NaOH}$ with nitric acid. The "acid equivalents" shown for this sample is the base equivalents. Denotations "nm" and "Itd" stand for "not measured" and "less than detectable", respectively.

\subsection{Test Apparatus}

A laboratory scale evaporator was fabricated as shown in Appendix B. The evaporator consists of an evaporation vessel with stir bar, a stirring hotplate, an aluminum heat transfer plate, wire mesh demister, a condenser with recirculating water bath, and a condensate collection vessel. A feed tank and pump was utilized to feed the simulated recycle to the evaporator during the run.

Antifoam tests were conducted using an evaporator with internal heating coil, a hotplate, condenser with recirculating chiller, and a condensate collection tank. This apparatus is also shown in Appendix B. A continuous evaporation was performed with this apparatus by adding a feed system and a condensate removal system. 
Scaling parameters for both apparatus are shown in Table 2. The full-scale values are based on a conceptual design proposed by a consultant hired by DWPF to evaluate the feasibility of installing the recycle evaporator in the DWPF Salt Process Cell. The parameters for the DWPF SRAT vessel and 4-L SRAT apparatus are shown for comparison.

Table 2. Scaling Parameters

\begin{tabular}{|c|c|c|c|c|c|}
\hline & Full-Scale & $\begin{array}{c}\text { DWPF } \\
\text { SRAT }\end{array}$ & $\begin{array}{c}\text { Antifoam } \\
\text { Test } \\
\text { Apparatus }\end{array}$ & $\begin{array}{c}\text { Boil-Down } \\
\text { Test } \\
\text { Apparatus }\end{array}$ & $\begin{array}{c}\text { 4-L SRAT } \\
\text { Lab } \\
\text { Apparatus }\end{array}$ \\
\hline Diameter (inches) & 60 & 144 & 3.25 & 2.4 & 5 \\
\hline Boil-Up Rate (g/min) & 28000 & 38000 & 14 & 2.5 & 4 \\
\hline Flux Rate (g/min-in ${ }^{2}$ ) & 9.20 & 2.33 & 1.7 & 0.6 & 0.2 \\
\hline Flux Rate (\% of full scale) & 100 & 25 & 17 & 7 & 2.2 \\
\hline Flux Rate (\% of SRAT) & 400 & 100 & 73 & 26 & 9 \\
\hline Heating Source & Steam & Steam & $\begin{array}{c}\text { Hotplate and } \\
\text { heating coil }\end{array}$ & $\begin{array}{c}\text { Hotplate w/ } \\
\text { aluminum } \\
\text { block }\end{array}$ & Mantle \\
\hline
\end{tabular}

\subsection{Run Performance}

The boil-down tests were performed in small vessels $(\sim 300 \mathrm{ml})$ to minimize the contribution of splatter and buildup to the material balance. The boil-up rate was approximately $3 \mathrm{ml} / \mathrm{min}$ during the water runs, but was reduced during several of the boil-down tests to reduce foam height. The level in the evaporator was maintained as close as possible to $100 \mathrm{ml}$ throughout the run by matching feed additions to the boiloff rate. The process steps utilized during the run are shown in Appendix B.

\subsection{Sample Analysis Methods}

Samples were taken and submitted for analysis as outlined in the Analytical Study Plan. ${ }^{11}$ Samples were taken of each simulant and blended feed stream prior to each run. Samples of the concentrate and condensate were taken at the conclusion of each run. Measurements of solids content, density, $\mathrm{pH}$, viscosity, and acid/base titrations were conducted by Immobilization Technology Section (ITS) at the Aiken County Technology Laboratory (ACTL). Sample composition was measured by ITS at the Mobile Lab (ML) for all species except mercury. Mercury and XRD analysis was performed by the Analytical Development Section (ADS). Each analysis was performed as outlined below.

\subsection{1 pH}

An IQ Scientific model IQ150 $\mathrm{pH}$ probe was utilized to measure the $\mathrm{pH}$ of the samples. This instrument is an ion-selective $\mathrm{pH}$ meter with automatic temperature measurement and compensation. The instrument was checked with $\mathrm{pH} \mathrm{4,} \mathrm{7,} \mathrm{and} 10$ buffers before and after use. 


\subsubsection{Density}

An Anton Paar DMA-4500 density meter was utilized to determine the density of samples. This instrument utilizes the dampening of a vibrating u-tube to measure density. The instrument was checked with DI water prior to each use.

\subsubsection{Solids Content}

The solids content was measured with a Mettler-Toledo HR83 halogen moisture meter. The solids content of the slurry and the solids content of supernate were measured. Supernate was prepared by filtration of the slurry through a syringe filter. The insoluble and soluble solids content were calculated from the results. The instrument was checked with standards before and after use.

\subsubsection{Viscosity}

Viscosity was measured with a Haake RS-600 rheometer using the 0.5 degree, $60 \mathrm{~mm}$ cone and plate geometry at a single shear rate $\left(2000\right.$ seconds $\left.^{-1}\right)$. The instrument was checked with viscosity standards before each use.

\subsubsection{Mobile Laboratory Measurements}

The ML performed metals analysis utilizing ICP-ES and anion analysis using IC-Anions. A peroxide fusion digestion was performed on the samples prior to ICP-ES measurements. Standards and blank analysis were performed before and after each set of analytical runs.

\subsubsection{Titrations}

The initial samples from this study were titrated at ACTL using a Mettler-Toledo DL40GP autotitrator. The standard titration method utilized two milliliters of sample diluted into approximately sixty ml of DI water. $0.1 \mathrm{M}$ hydrochloric acid or sodium hydroxide solution was added while the sample was mechanically agitated. $\mathrm{pH}$ is continuously monitored during the acid addition. Duplicate analysis was performed on each sample and the results were averaged. Results were rejected if the difference between the duplicate samples was greater than $10 \%$.

The autotitrator failed during the test program, therefore direct titration using manual additions of sodium hydroxide to the sample was utilized. The $\mathrm{pH}$ probe utilized during the direct titration tests was the same as for the $\mathrm{pH}$ measurements. The direct titration method utilized approximately $5 \mathrm{ml}$ of sample diluted to $20 \mathrm{ml}$ with DI water. The sample was continuously mixed while $0.1 \mathrm{ml}$ additions of sodium hydroxide solution was added. The $\mathrm{pH}$ was allowed to stabilize between each addition and was recorded prior to the next addition. A plot of $\mathrm{pH}$ versus amount of acid added per ml of sample was generated and the intercept of the $\mathrm{pH}$ curve with $\mathrm{pH}=7$ was determined. Two measurements were taken for each sample and the results checked for consistency.

\subsubsection{Vapor Pressure}

Vapor pressure measurements were planned using two Grabner MiniVap VOC instruments, but both instruments failed during initial water checks and repairs were not performed. The measurements were intended to help validate the OLI models and to provide temperature data to aid in evaluation of vacuum operation of the evaporator. The OLI validation was completed without the vapor pressure data using the 
data from the boil-down tests and vacuum operation is not currently planned, therefore the vapor pressure data is not required to complete the task.

\subsubsection{ADS Measurements}

Mercury was analyzed using atomic adsorption cold vapor methods after digestion with aqua regia. Standards were analyzed before and after each set of analytical runs.

XRD analysis was performed on solids filtered onto filter paper. The supernate from the solids filtration was filtered through a second filter and submitted with the solids to provide a "blank" to determine if solids in the XRD analysis are from the supernate or solids content of the sample.

\subsection{RESULTS}

All six of the scenarios outlined above were tested and Scenario 1 was tested in triplicate ${ }^{12,13}$. The sample results from the tests are shown in Appendix C. DF's were calculated for each species based on the sample results. Foaming was noted in all runs, with severe foaming occurring in some of the runs. Foaming was controlled by reducing the boil-up rate. No evidence of precipitation was noted during any of the runs. Scaling below the liquid surface was not noted, but splattering of particulate onto the vessel led to some solids deposition on the vessel walls above the foam layer.

\subsection{Foaming}

Foaming during the evaporation process was noted to some extent during all runs. Foam was controlled during the tests by reducing the boil-up rate. The reduced boil-up rate lowered the vapor flux rate at the liquid surface and significantly reduced the amount of foam in the evaporation vessel. The flux rate for the boil-down tests was less than $10 \%$ of the flux rate in the conceptual design for the evaporator proposed by Bennett, as shown above in Table 2. Higher flux rates would have led to increased foaming, therefore the foaming noted during the boil-down tests was noted as a concern for operation of the recycle evaporator. The maxima in foam height were observed for the runs at the onset of boiling with a gradual decrease in foam height noted as the runs progressed, as shown in Figure 1. Foaming was least in the run during evaporation of Scenario 3 (OGCT only) recycle.

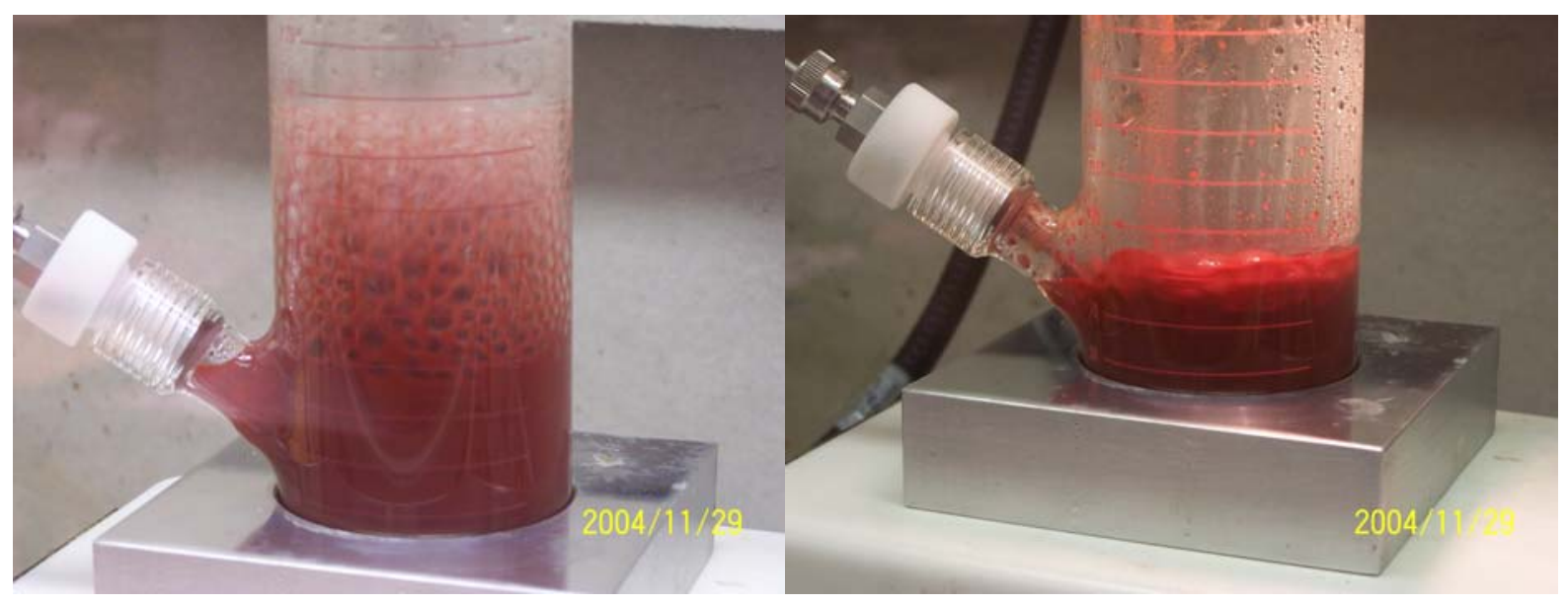

Figure 1. Foaming during Initial and Final Stages of Scenario 1, Run 1 Evaporation 
Scaling of foaming phenomena is difficult from tests conducted in small-scale apparatus due to the effects of the vessel walls in stabilizing foam lamellas. The "wall effect" is appreciable in the small-scale tests but disappears on scale-up. The wall effect is especially pronounced if the diameter of the bubbles in the foam lamella are greater than 1/3 the diameter of the vessel. As shown in the above figures, bubbles during the boil-down tests were much smaller than the vessel and the amount of foam noted was not attributed to wall effects.

Additional tests were conducted to study the potential for foam formation and to evaluate the performance of antifoams recommended by Dow Corning and the antifoams identified for use in the Hanford RPP project (Dow Corning Q2-3183A). These tests were conducted in a larger diameter vessel with increased flux rates to better simulate the full-scale process. The tests were conducted by charging $700 \mathrm{ml}$ of feed to the vessel and evaporating until $400 \mathrm{ml}$ of condensate had been collected. Antifoam (1000 ppm) was added prior to the heating the vessel to boiling.

A water run was conducted to determine the maximum boil-up rate and the height of vapor disengagement in the vessel with a non-foaming liquid. During this run, full power (1000 watts) on the coil and a temperature setting of $500^{\circ} \mathrm{C}$ on the hotplate yielded a boil-up rate of 25 grams per minute. Vapor disengagement amounted to approximately $100 \mathrm{ml}$ during the run. A baseline run without antifoam was then conducted. The foam quickly rose in the vessel to a height greater than $2000 \mathrm{ml}$ (height of last graduation line) and would likely have foamed over in the condensate collection vessel if the coil power had not been reduced to 600 watts. The foam level remained above $2000 \mathrm{ml}$ until the conclusion of the run. All subsequent tests were conducted at 600 watts to allow direct comparison to this test and prevent foam-over if the antifoam tested was ineffective.

The next test was conducted with Dow Corning Q2-3183A. The foam height at the onset of boiling was significantly reduced, but the foam level was judged to be excessive and an additional $1000 \mathrm{ppm}$ of the antifoam was added. Foam control during this run was not deemed adequate, and additional tests were performed with antifoams recommended by Dow Corning (1430, 2210, and DSP). As shown in Figure 2, foam control with these antifoams was much improved over the Q2 3183A antifoam and all three antifoams performed similarly.
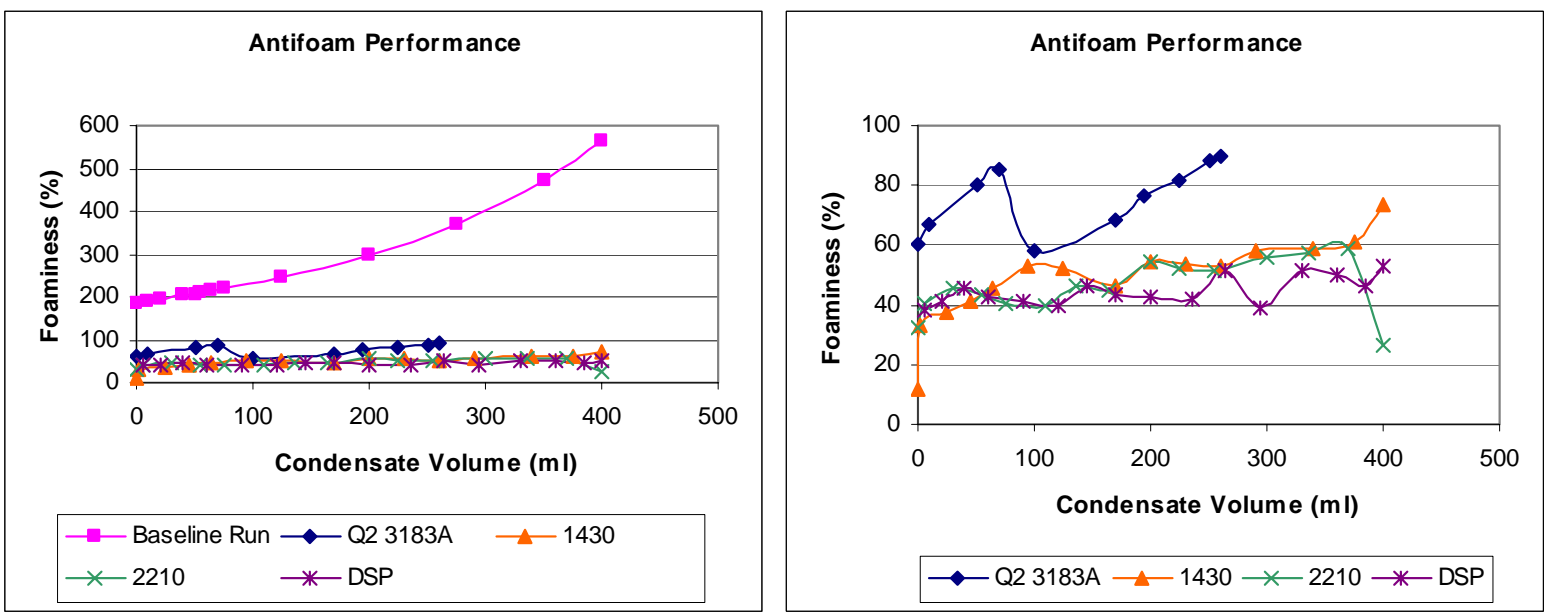

Figure 2. Performance of Antifoams

Severe flocculation of the feed material was noted in both the 2210 and DSP antifoam tests, as shown in Figure 3. The flocculation occurred just prior to the onset of boiling and resulted in the solution 
appearance changing from a red, opaque slurry to a clear liquor containing large red chunks. A significant portion of the solids were trapped in a surface film. This film was agitated and mixed into the body of the solution at the onset of boiling. Antifoams often contain flocculating agents to aid in foam control, therefore the severe flocculation noted could have been the result of the addition of more antifoam than required. As the run progressed, the solids began to break apart and the appearance of the slurry at the conclusion of the tests was similar to the baseline run.

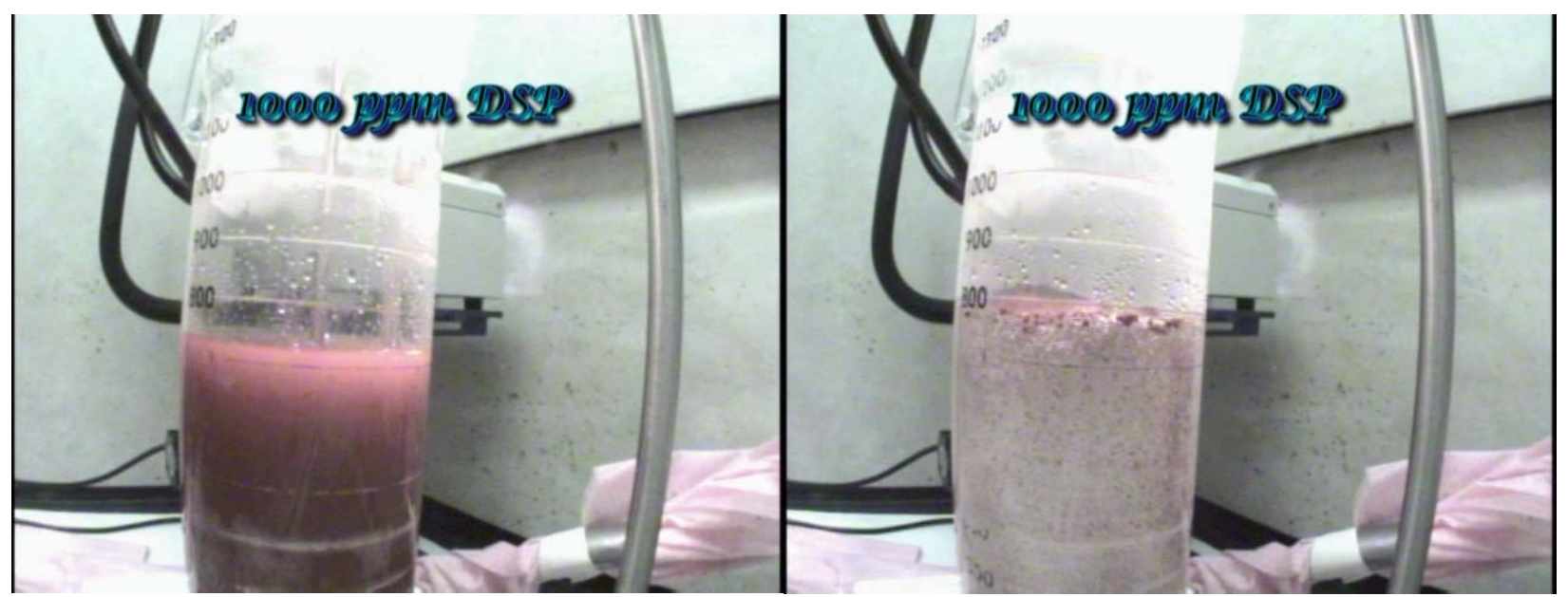

Figure 3. Flocculation during Addition of DSP Antifoam

A test run was performed with DSP antifoam to determine the concentration of the antifoam required to control the foam and to determine how often additional antifoam would be required during evaporator operation. The antifoam test apparatus was modified to allow continuous operation and the test was performed. An initial charge of $700 \mathrm{ml}$ was added to the evaporation vessel and the run was started. Feed material was added to match the boil off amounts to maintain the level in the evaporator at $700 \mathrm{ml}$ and the feed was concentrated 30X.

Antifoam was added in small amounts until the foam height was less than $1200 \mathrm{ml}$, with approximately $\sim 700 \mathrm{ppm}$ required. Additional $100 \mathrm{ppm}$ antifoam additions were required after approximately 30 minutes to keep the foam height below $1200 \mathrm{ml}$. As the initial foaming subsided, less antifoam was required. While the foam was stable, an additional charge of DSP antifoam was added to determine if the foam height would be reduced. The foam height increased significantly after addition, and 100 ppm 2210 antifoam was added to control the foam, as shown in Figure 4. No additional antifoam was required, but an additional charge of 2210 antifoam was added to determine if the stable foam height could be reduced. Very little reduction in the foam height was noted, but the foam height did not increase as was noted with the DSP antifoam. 


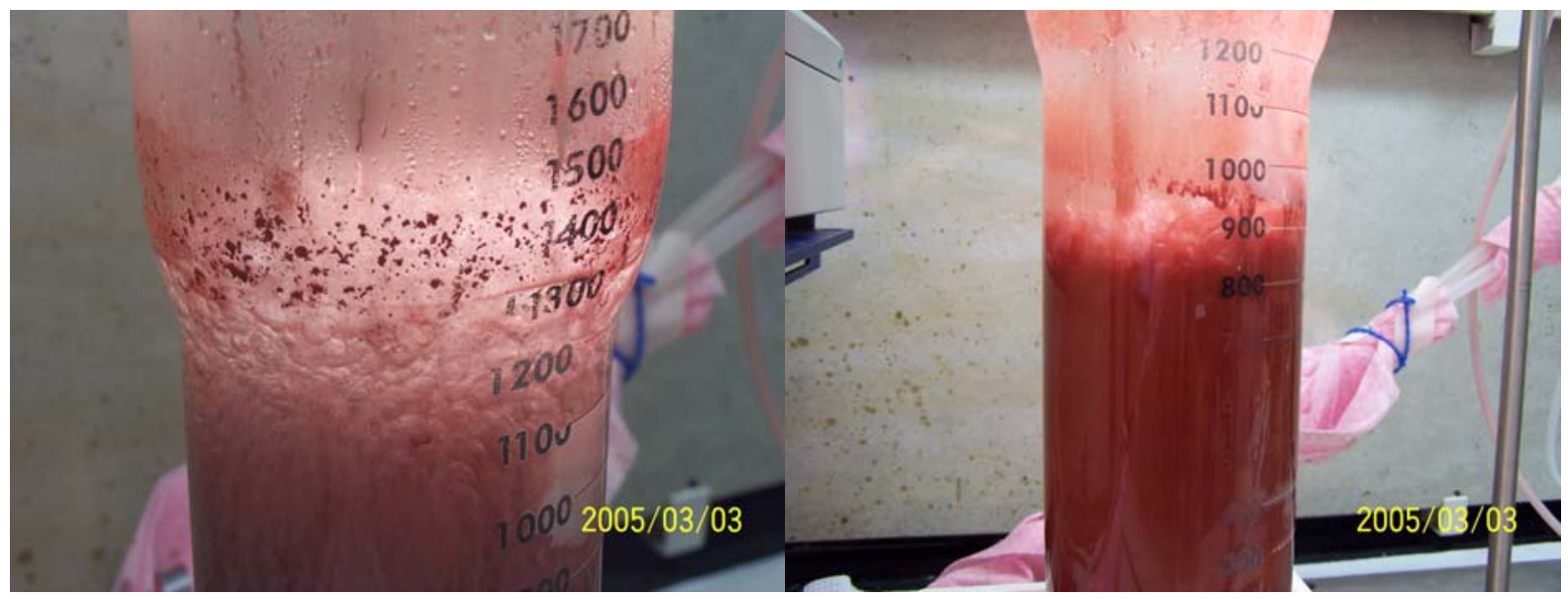

Figure 4: Foaming During Antifoam Tests with DSP and After 2210 Addition

\subsection{Condensate Characterization}

The condensate was sampled at the conclusion of the test run, but this sample did not represent an aggregate sample of all condensate from the run. Condensate was collected continuously during the test run, but was removed batch wise when the condensate collection tank was filled. A small heel was left in the collection vessel during each transfer. The evaporator contents at the start of the run matched the feed composition, therefore the condensate generated during the initial portion of the run would not be representative. The first three liters of feed were required to reach steady-state concentration in the evaporator. An additional liter of feed was fed during steady-state operation; condensate from this stage of operation was contained in the sample at the conclusion of the run. The Scenario 4 condensate sample represents the last sample pulled prior to the foam over. All condensate bottles were analyzed for $\mathrm{pH}$, results are shown in Appendix E. The sample results obtained for the condensate are shown in Appendix $\mathrm{C}$ and were compared to the ETP WAC for the Waste Water Collection Tank (WWCT) ${ }^{14}$. Major species noted in the condensate are shown in Table 3.

Table 3. Major Species in Recycle Evaporator Condensate

\begin{tabular}{|c|c|c|c|c|c|c|c|}
\hline Scenario \# & Description & $\mathrm{Hg}$ & $\mathrm{Si}$ & Nitrate & Formate & TOC* & $\mathrm{pH}$ \\
\hline \multicolumn{2}{|c|}{ ETP WAC Acceptance Limits for the } \\
WWCT & 40.6 & 99.2 & 1180 & & 385 & $1-12.5$ \\
\hline & & $\mathrm{ppm}$ & $\mathrm{ppm}$ & $\mathrm{ppm}$ & $\mathrm{ppm}$ & $\mathrm{ppm}$ & \\
\hline $1-1$ & "Typical" Operation & 152 & 408 & 429 & 361 & 96 & 2.2 \\
\hline $1-2$ & "Typical" Operation & 12 & 67 & 284 & 398 & 106 & 2.4 \\
\hline $1-3$ & "Typical" Operation & 77 & 67 & 420 & 434 & 116 & 2.3 \\
\hline 2 & Melter Idled & 17 & 1120 & 703 & 819 & 218 & 1.9 \\
\hline 3 & CPC Idled & 0 & 0 & 0 & 0 & 0 & 3.0 \\
\hline 4 & HEME Dissolution & 36 & 28 & 840 & 0 & 0 & 2.0 \\
\hline 5 & Decon Operation & 20 & 0 & 1080 & 3015 & 804 & 2.0 \\
\hline 6 & Salt Operations & 23 & 9.5 & 172 & 177 & 47 & 2.5 \\
\hline
\end{tabular}

* Calculated from formate concentration. 
The WAC for mercury, silicon, and organic carbon was exceeded during at least one of the test runs. The mercury results contained a significant amount of scatter and are discussed below. The silicon noted for Scenario 1-1 may be an outlier, but the result from Scenario 2 is well above the limits and is consistent with the larger amounts of silicon-based antifoam that would be present during a run that only contains material from the CPC operations. The run with high TOC contained a large amount of formate in the SME solids dissolved in the decon solution. Limiting the amount of decon solution in the evaporator feed would likely prevent formate from exceeding the limit.

Beads of mercury were noted in the condensate collection vessel for all runs except Scenario 3 (OGCT only). Based on the presence of elemental mercury beads in the condensate, the condensate was saturated with Hg. Typically, the saturation point of a solution is $\mathrm{pH}$ dependant. However, the concentration of $\mathrm{Hg}$ in the condensate samples varied from run to run at the same $\mathrm{pH}$. These data suggest that the saturation point of mercury in the condensate samples was not merely a function of the $\mathrm{pH}$. A possible explanation for the different concentrations noted for the three runs of Scenario 1, could be due to the reducing and oxidizing agents present in the samples. The presence of oxidizing and reducing agents is known to impact the solubility of mercury.

A "silicon reactant" was shown on several draft versions of the evaporator flowsheets prepared by DWPF-E. This reactant was developed to lower the risk of sodium alumino-silicate formation in waste evaporators in the tank farm ${ }^{15}$. The reactant (ferric nitrate) was to be added to recycle after caustic adjustment and would co-precipitate with the sodium meta-silicate in solution. The reactant would not function in an acidic stream (as planned for the recycle evaporator) and would likely not react with the siloxanes in the recycle stream from antifoam degradation products.

\subsection{Concentrate Characterization}

The concentrate from each boil-down test was sampled and characterized and are shown in Appendix C. A concentration factor was calculated for each species in the concentrate by dividing the concentrate concentration by the feed concentration and these values are also shown in Appendix C. The concentrate from Scenario 4 was lost when the evaporator foamed over into the condensate.

The concentration factors vary somewhat from the concentration target due to uncertainties in the sample analysis and the errors in determining the solution height during the run. The foaming in the evaporator led to difficulty in the determination of the liquid height during the run. During steady state operation, errors in the level would have resulted in removal of concentrate that was too dilute or too concentrated. These errors led to some variability in the actual concentration of the final sample.

All runs except Scenario 4 were able to achieve the concentration target, within the uncertainties described above and resulted in concentrate that was free flowing. Solids contents ranged from 3 to $30 \%$, dependent on the solids content of the incoming feed, with a nominal value of $10 \%$ for runs without DWTT content. The solids content of the DWTT stream raises the solids content of the feed considerably. The amount of HEME dissolution material in Scenario 4 resulted in a feed that would have exceeded $100 \%$ solids if concentrated $30 \mathrm{X}$, resulting in a foam over when the feed became too concentrated for the evaporator apparatus. The run with coil decontamination solution from the DWTT reached $30 \%$ solids content.

\subsection{Precipitation}

No precipitation of solids was noted during the runs, based on visual observations during the runs and XRD results. Results from the solids analysis were inconclusive due to the small amount of solids 
originally present. Figure 5 and Figure 6 are typical XRD results for the feed and concentrate samples and are from Scenario 1. The remaining XRD diagrams are shown in Appendix D. Note that much of the gibbsite noted in the feed is converted to aluminum oxide during the evaporation process.

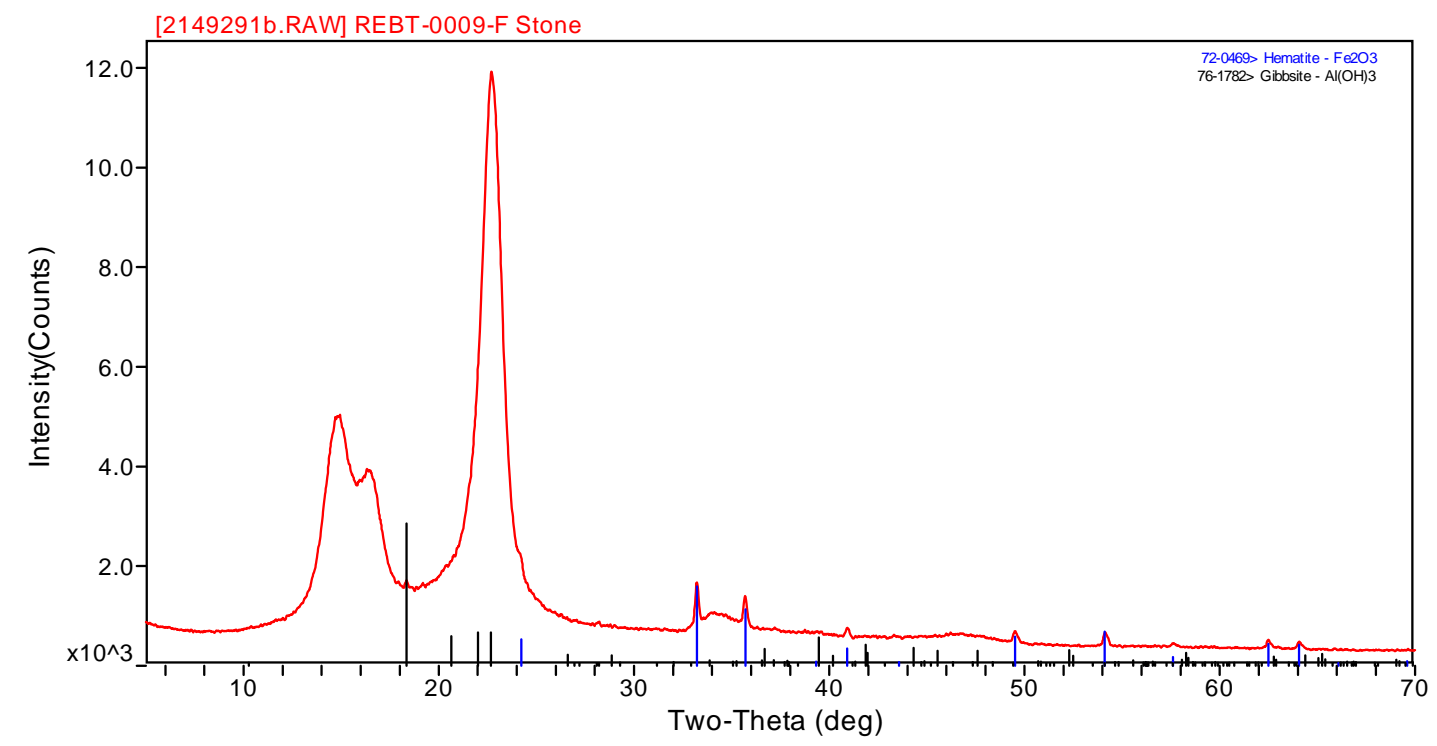

Figure 5. XRD from Scenario 1 Feed Sample

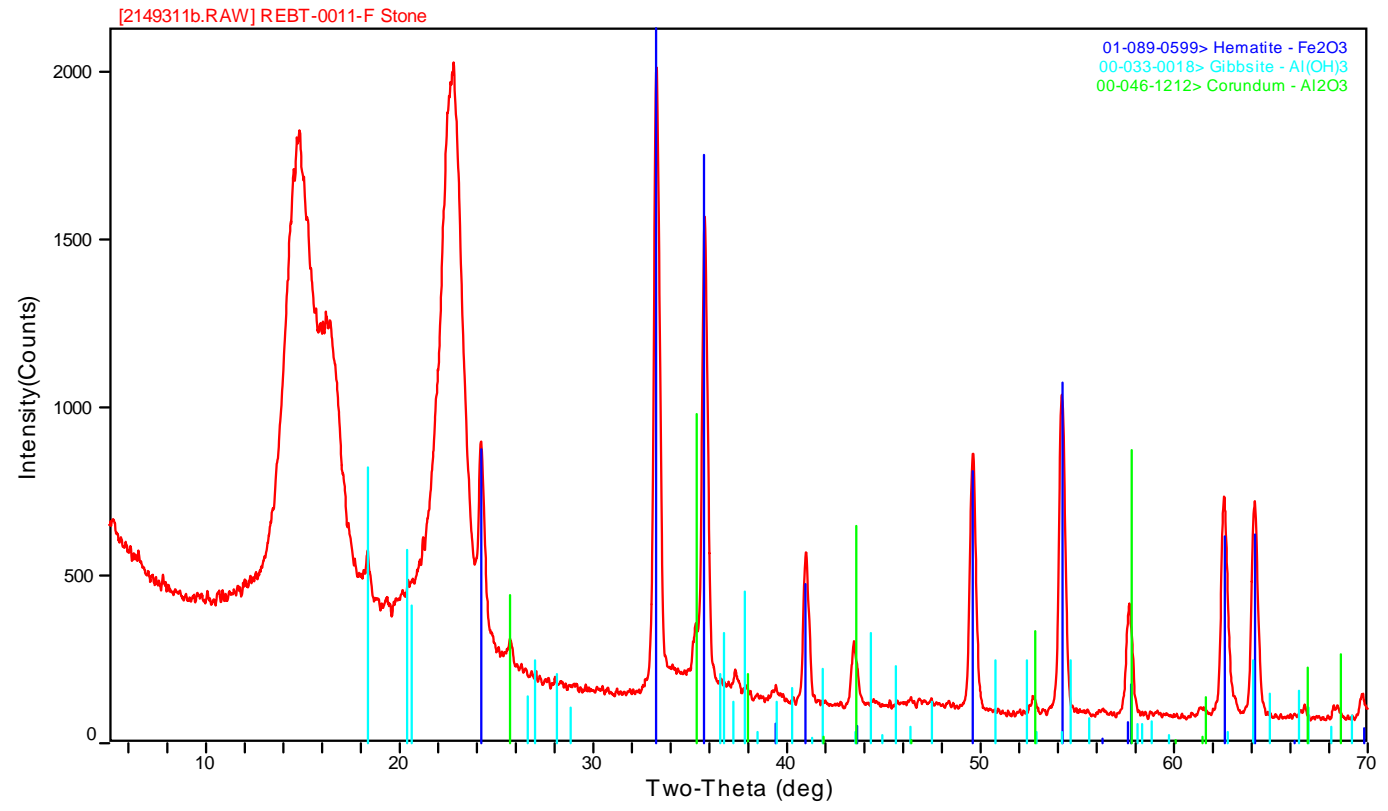

Figure 6. XRD from Scenario 1 Concentrate Sample 


\subsection{Scaling}

Visual observations of the evaporation apparatus after each test were conducted to determine if scaling was occurring. During all runs, the boiling surface was vigorous and caused some splatter of solids onto the vessel walls. These solids tended to stick to the walls, as shown in Figure 7 and were not washed off by the limited amount of internal reflux that occurred during the runs. The solids deposited on the walls were not easily removed by 2M nitric acid rinses. Two of the antifoams (Q2-3183A and 1430) led to a film formation above the foam line during antifoam testing. This film was easily cleaned from the vessel with water. The flocculation caused by 2210 and DSP antifoams led to larger particles being deposited on the walls, but these particles were easily removed during cleaning.

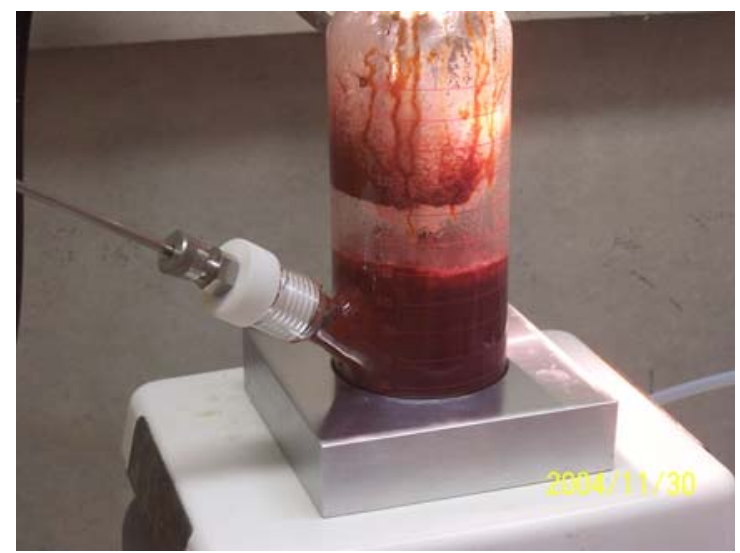

Figure 7: Scale Buildup on Walls during Scenario 1-1

During antifoam testing, a stainless steel heating coil was utilized. No significant deposition was noted on the heating surface during the tests.

\subsection{Evaporator DF}

The evaporator DF was calculated for each species present in the feed samples based on the sample results from the feed and condensate for each run. When the condensate results indicated less than detectable amounts, the detection limit was utilized to determine the DF. The average results along with the lowest and highest value are shown in Table 4 for selected species. All results are shown in Appendix F. Values shown in italics in Table 4 and Appendix F are based on the sample detection limits. 
Table 4. Evaporator DF for Selected Species

\begin{tabular}{|c|c|c|c|c|}
\hline & $\begin{array}{c}\text { Sample } \\
\text { Detection } \\
\text { Limit }\end{array}$ & Low & Average & High \\
\hline $\mathrm{Al}$ & 0.1 & 5 & 355 & 2255 \\
\hline $\mathrm{B}$ & n/a & 1.2 & 10 & 22 \\
\hline $\mathrm{Fe}$ & 0.04 & 2663 & 22138 & 46750 \\
\hline $\mathrm{K}$ & n/a & 4 & 38 & 155 \\
\hline $\mathrm{Hg}$ & 2.5 & 1.0 & 13 & 64 \\
\hline $\mathrm{Mo}$ & n/a & 2 & 20 & 44 \\
\hline $\mathrm{Si}$ & n/a & 0.05 & 8 & 33 \\
\hline $\mathrm{NO}_{3}$ & n/a & 7 & 13 & 29 \\
\hline $\mathrm{HCO}_{2}$ & n/a & 0.80 & 1.08 & 1.39 \\
\hline
\end{tabular}

Several issues with the DF's should be noted. The small evaporator size utilized during the boil-down tests could have impacted the results and no attempts were made to make the vent system "prototypical". A crude demister was utilized during the test which consisted of a steel mesh wrapped into a cylinder and forced into the offgas line. This demister was likely less efficient than a commercially designed unit. Deposition of selected species on the walls of the offgas system could have raised the apparent DF for that species.

The DF for each element in the table above was evaluated graphically to determine if trends existed in the DF of the component and the feed concentration. The graphs indicate that DF is a function of feed composition for selected species and that higher feed concentrations led to higher DFs, as shown in Figure 8. Graphs for other species, except formate, are shown in Appendix F.
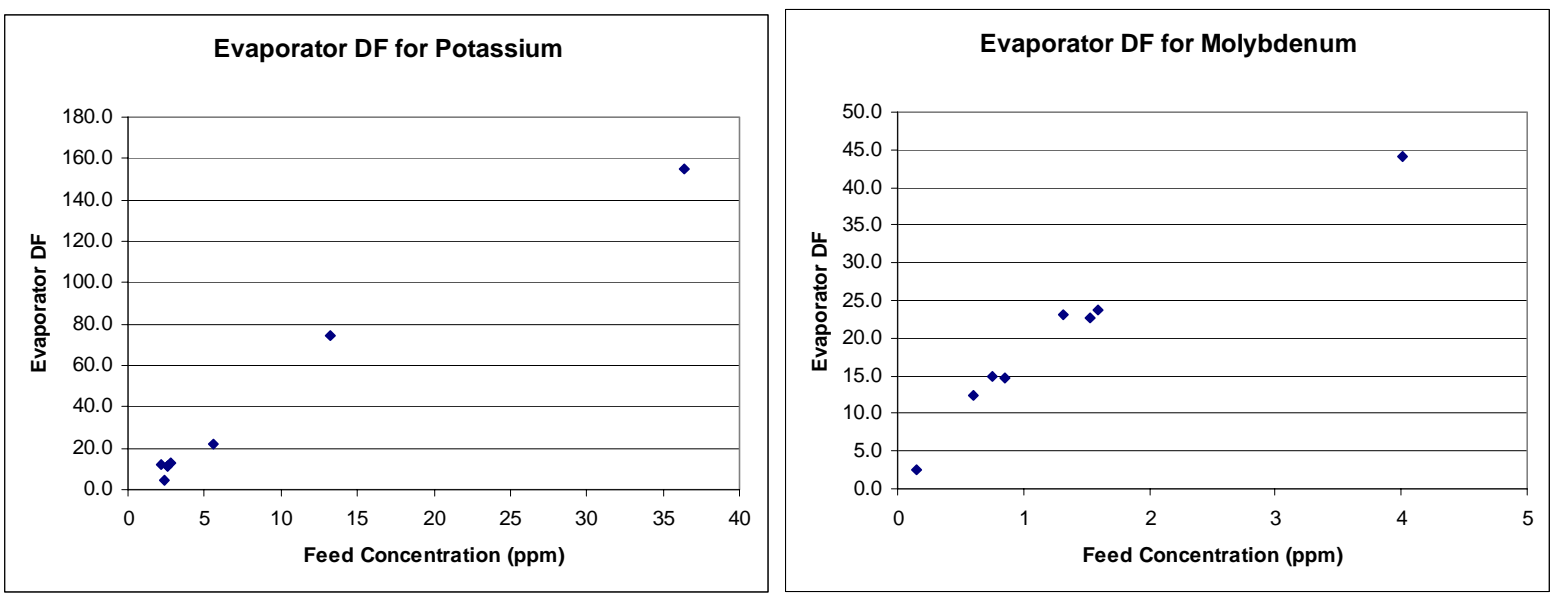

Figure 8. DF for Potassium and Molybdenum 
Other species had DF's that were not a function of feed composition. These elements included silicon whose DF was a function of the type of silicon present, not the amount. Other elements such as boron also did not indicate a trend with feed composition, but the cause is not known. The detection limit was utilized to calculate the DF for most species, therefore trending could not be performed.

A review of the results for selected species was performed to determine the magnitude of the impacts of the issues listed above. The relatively high DF values for iron indicate that entrainment of drops into the offgas system was not excessive, therefore, foaming is likely not the cause of the low DF's seen for some species. When the DF for silicon is examined, runs with large amounts of frit had much higher DF's than runs with larger amounts of siloxanes from the antifoam. The presence of elemental mercury beads in the condensate collection indicates that the holdup of mercury on vessel and tubing walls did not affect the amount of mercury seen in the condensate.

\subsection{CONCLUSIONS}

Concentration of the "typical" recycle stream in DWPF by 30X was feasible. The addition of DWTT recycle streams to the typical recycle stream raises the solids content of the evaporator feed considerably and lowers the amount of concentration that can be achieved.

Foaming was noted during all evaporation tests and must be addressed prior to operation of the full-scale evaporator. Tests were conducted that identified Dow Corning 2210 as an antifoam candidate that warrants further evaluation.

The condensate has the potential to exceed the ETP WAC for mercury, silicon, and TOC. Controlling the amount of equipment decontamination recycle in the evaporator blend would help meet the TOC limits. The evaporator condensate will be saturated with mercury and elemental mercury will collect in the evaporator condensate collection vessel.

No scaling on heating surfaces was noted during the tests, but splatter onto the walls of the evaporation vessels led to a buildup of solids. These solids were difficult to remove with $2 \mathrm{M}$ nitric acid. Precipitation of solids was not noted during the testing.

Some of the aluminum present in the recycle streams was converted from gibbsite to aluminum oxide during the evaporation process.

\subsection{RECOMMENDATIONS}

Recycle from the DWTT should be metered in slowly to the "typical" recycle streams to avoid spikes in solids content to allow consistent processing and avoid process upsets. Additional studies should be conducted to determine acceptable volume ratios for the HEME dissolution and decontamination solutions in the evaporator feed.

Dow Corning 2210 antifoam should be evaluated for use to control foaming. Additional tests are required to determine the concentration of antifoam required to prevent foaming during startup, the frequency of antifoam additions required to control foaming during steady state processing, and the ability of the antifoam to control foam over a range of potential feed compositions. This evaluation should also include evaluation of the degradation of the antifoam and impact on the silicon and TOC content of the condensate. 
The caustic HEME dissolution recycle stream should be neutralized to at least $\mathrm{pH}$ of 7 prior to blending with the acidic recycle streams.

Dow Corning 2210 should be used during the evaporation testing using the radioactive recycle samples received from DWPF.

Evaluation of additional antifoam candidates should be conducted as a backup for Dow Corning 2210 .

A camera and/or foam detection instrument should be included in the evaporator design to allow monitoring of the foaming behavior during operation.

The potential for foam formation and high solids content should be incorporated into the design of the evaporator vessel. 


\subsection{REFERENCES}

${ }^{1}$ W. R. Wilmarth, "Results of Aluminosilicate Formation Testing”, WSRC-TR-2001-00330, September 11, 2001.

${ }^{2}$ D. P. Lambert, C. D. Barnes, S. G. Phillips, “DWPF Recycle Evaporator - Feasibility Study”, WSRC-RP-200101101, January 18, 2002.

${ }^{3}$ A. V. Staub, "Process Development for DWPF Recycle Acid Evaporator”, HLW/DWPF/TTR-04-0020, Rev. 1., October 18, 2004.

${ }^{4}$ M. E. Stone, “DWPF Recycle Evaporator Boil-Down Tests”, WSRC-RP-2004-00648, September 24, 2004.

${ }^{5}$ J. E. Occhipinti and A. V. Staub, "Estimated Stream Compositions for DWPF Recycle Influents”, CBU-WSE2004-00177, September 27, 2004.

${ }^{6}$ T. L. Fellinger, and N. E. Bibler, "Results for the DWPF Slurry Mix Evaporator Condensate Tank, Off Gas Condensate Tank, and Recycle Collection Tank (U)”, WSRC-TR-2004-00577, November 19, 2004.

${ }^{7}$ T. L. Fellinger, and N. E. Bibler, "Results for the DWPF Decontamination Waste Treatment Tank Samples (U)", WSRC-TR-2005-00036, January 25, 2005.

${ }^{8}$ C. A. Cicero, “HEME and HEPA Filter Element Dissolution Process (U)”, WSRC-TR-92-549, November 23, 1992.

${ }^{9}$ J. E. Occhipinti and A. V. Staub, "Estimated Stream Compositions for DWPF Recycle Influents”, CBU-WSE2004-00177, September 27, 2004.

${ }^{10}$ M. E. Stone, “Simulant Recipes for DWPF Recycle Evaporator Tests (U)”, SRNL-GPD-2004-00061, November 8, 2004.

${ }^{11}$ M. E. Stone, “Analytical Study Plan for DWPF Acid Evaporator Samples (U)”, SRNL-GPD-2004-00058, October 26, 2004.

${ }^{12}$ Laboratory Notebook, “DWPF Recycle Evaporatory Boil-Down Tests”, WSRC-NB-2004-00151

${ }^{13}$ Laboratory Notebook, "DWPF Recycle Evaporation Boil-Down Tests 2”, WSRC-NB-2005-00026

${ }^{14}$ A. W. Wiggins, "F/H Effluent Treatment Project Waste Acceptance Criteria (U)”, X-SD-H-00009, December, 2004.

${ }^{15}$ W. R. Wilmarth, et al, “Removal of Silicon from High Level Waste Streams via Ferric Flocculation”, WSRC-MS2003-00759, June 25, 2003. 


\section{APPENDIX A. SIMULANT RECIPES}

Table A-1. DWTT Decon Solution

\begin{tabular}{|l|r|l|}
\hline Deionized Water & 985.7 & grams \\
\hline 70\% Nitric Acid & 14.29 & grams \\
\hline Dried SB3 SME Solids & 50 & grams \\
\hline Mercuric Oxide & 0.23 & grams \\
\hline
\end{tabular}

Table A-2. DWTT HEME Dissolution*

\begin{tabular}{|l|c|c|}
\hline Deionized Water & 997.5 & grams \\
\hline Sodium Hydroxide & 52.5 & grams \\
\hline HEME filter media & 6.55 & grams \\
\hline
\end{tabular}

* Solution was boiled until HEME filter disintegrated. Solution was neutralized with nitric acid prior to use.

Table A-3. SMECT Condensate Simulant

\begin{tabular}{|l|c|}
\hline Addition Chemical & Amount (grams) \\
\hline & 7.2238 \\
\hline 70\% Nitric acid & 0.3416 \\
\hline Mercuric nitrate hydrate & 0.3237 \\
\hline 90\% Formic acid & 3.7297 \\
\hline 1:10 757 Antifoam & Add to 1 liter \\
\hline Deionized Water &
\end{tabular}

Table A-4. OGCT Simulant Recipe

\begin{tabular}{|l|c|}
\hline Addition Chemical & Amount (grams) \\
\hline & 1.5532 \\
\hline 70\% Nitric Acid & 0.0639 \\
\hline 97.5\% Sulfuric Acid & 0.2000 \\
\hline 10\% Hydrofluoric Acid & 0.6153 \\
\hline Sodium Nitrate & 0.1356 \\
\hline $\begin{array}{l}\text { Calcium Nitrate } \\
\text { Tetrahydrate }\end{array}$ & 0.4001 \\
\hline Aluminum oxide & 2.9011 \\
\hline Ferric oxide & 0.0945 \\
\hline Magnesium Oxide & 0.1559 \\
\hline Manganese Oxide & 0.0674 \\
\hline Nickel Oxide & 0.2154 \\
\hline Mercuric Oxide & 0.1767 \\
\hline Leached Frit 418 & Fill to 1 liter mark \\
\hline DI Water &
\end{tabular}


Sample Flush Recipe

The sample flush was a 50-50 blend of SRAT and SME product from SB3 simulant tests.

Other Streams

All other streams were assumed to be primarily water and was added as deionized water during the evaporation testing. 


\section{APPENDIX B. EQUIPMENT DIAGRAMS AND OPERATION STEPS}

Evaporator Volume: $300 \mathrm{ml}$

Evaporator Diameter: $6 \mathrm{~cm}$

Top Ports: 4 \#7 Ace Threads

$124 / 40$ ground glass

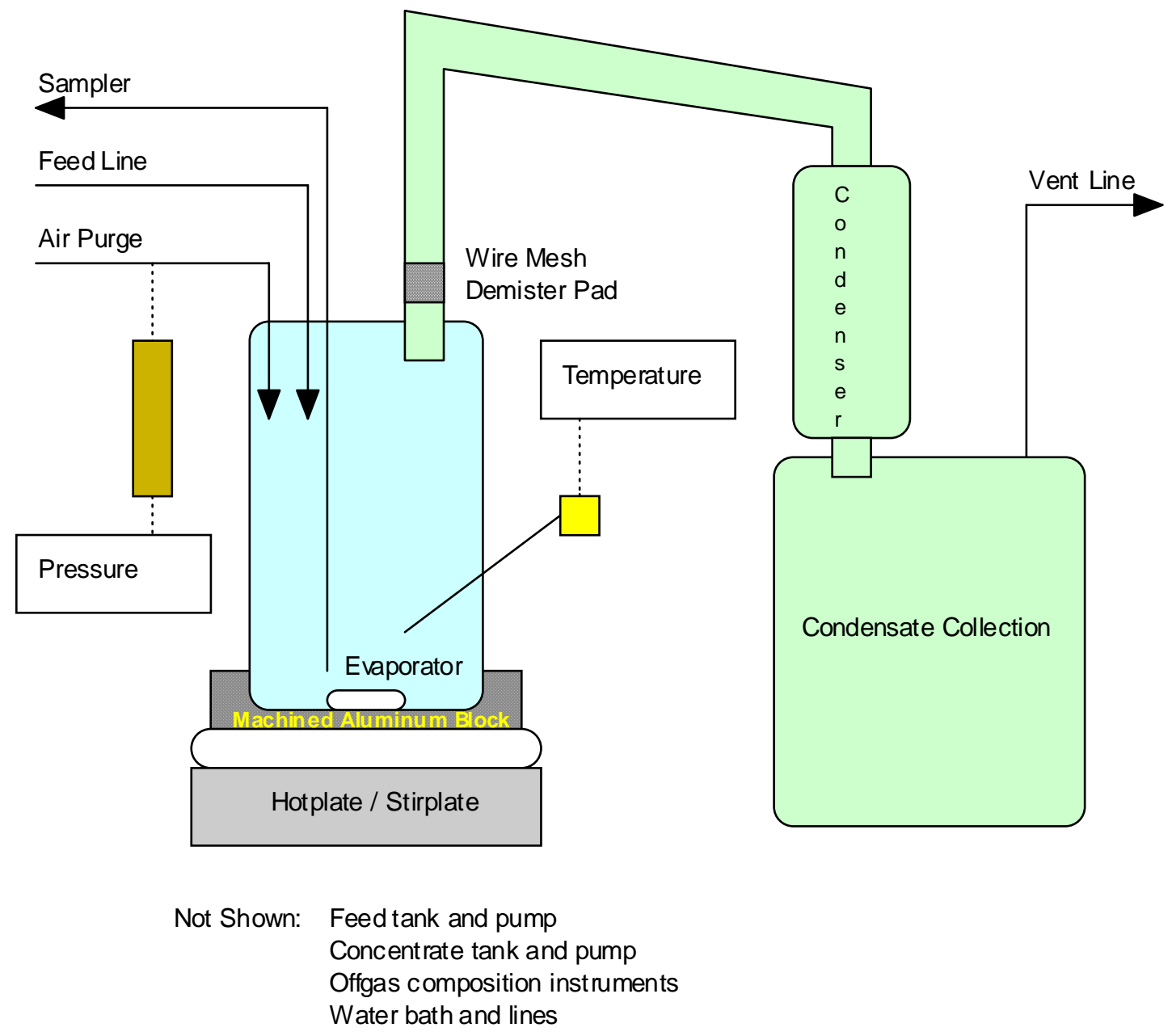

Figure B-1. Diagram of Evaporator for Boil Down Tests. 
WSRC-TR-2005-00142

Revision 0

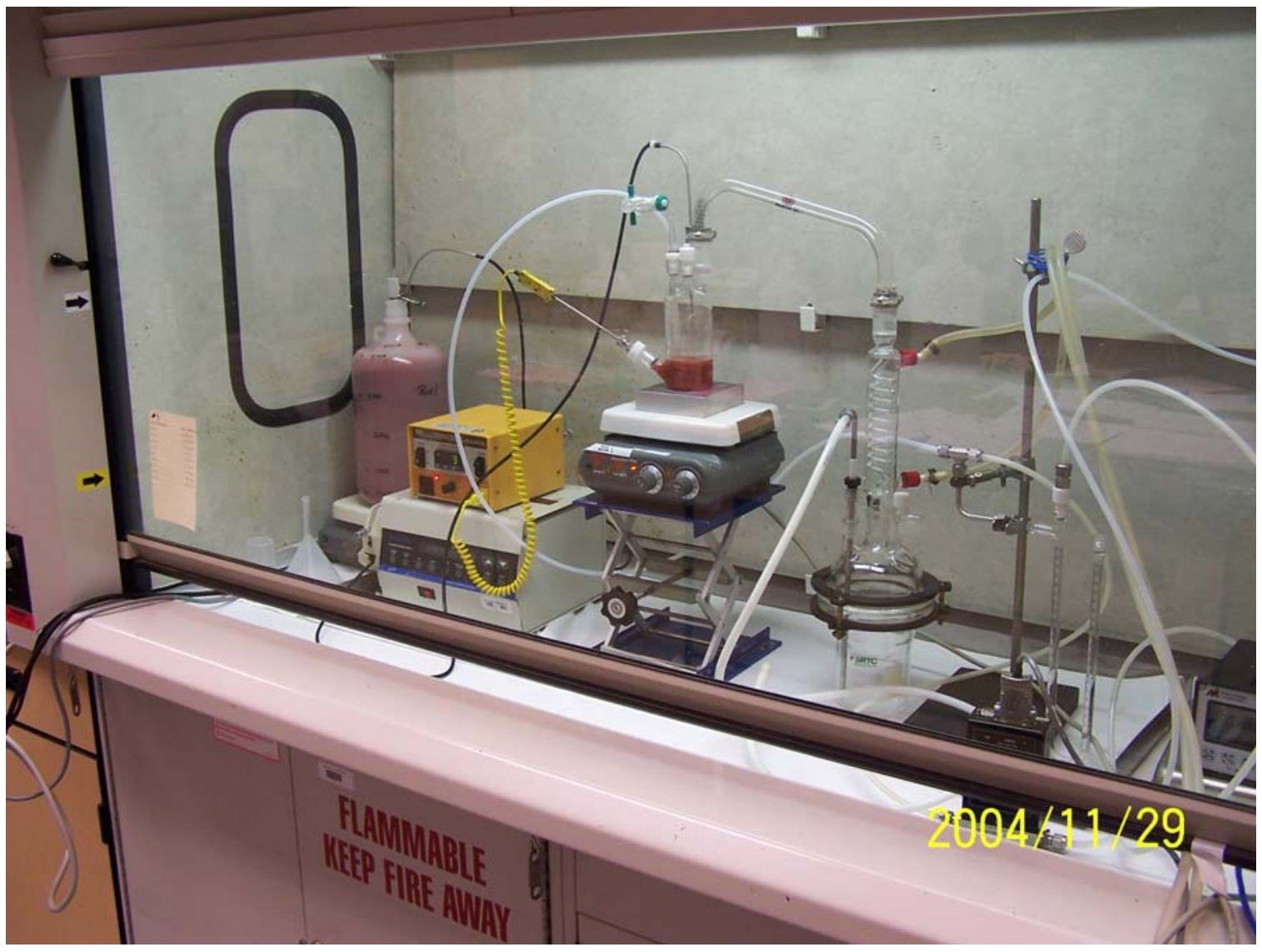

Figure B-2. Boil-Down Evaporator Photograph 
Revision 0

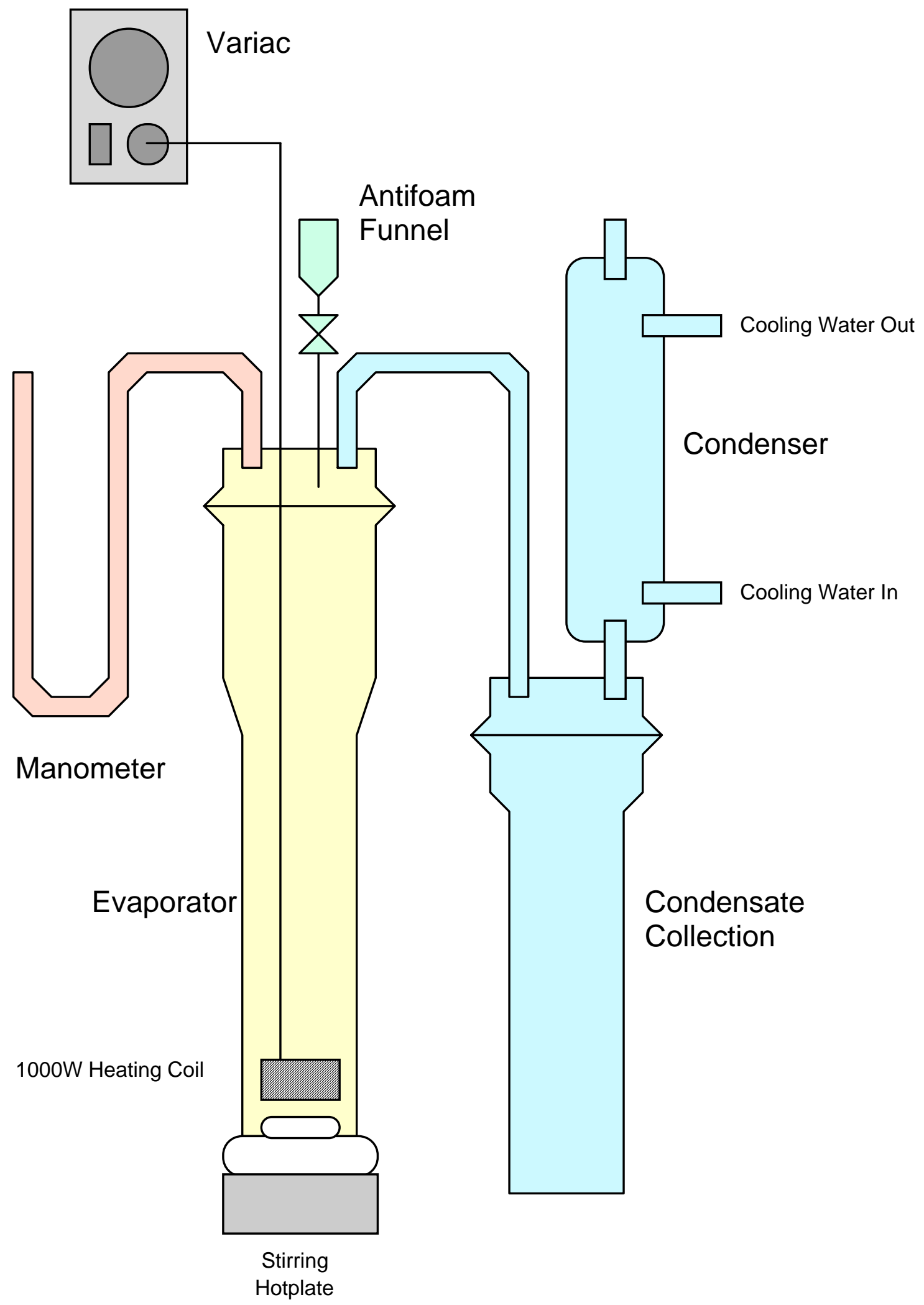

Figure B-3. Diagram of Evaporator for Antifoam Tests 


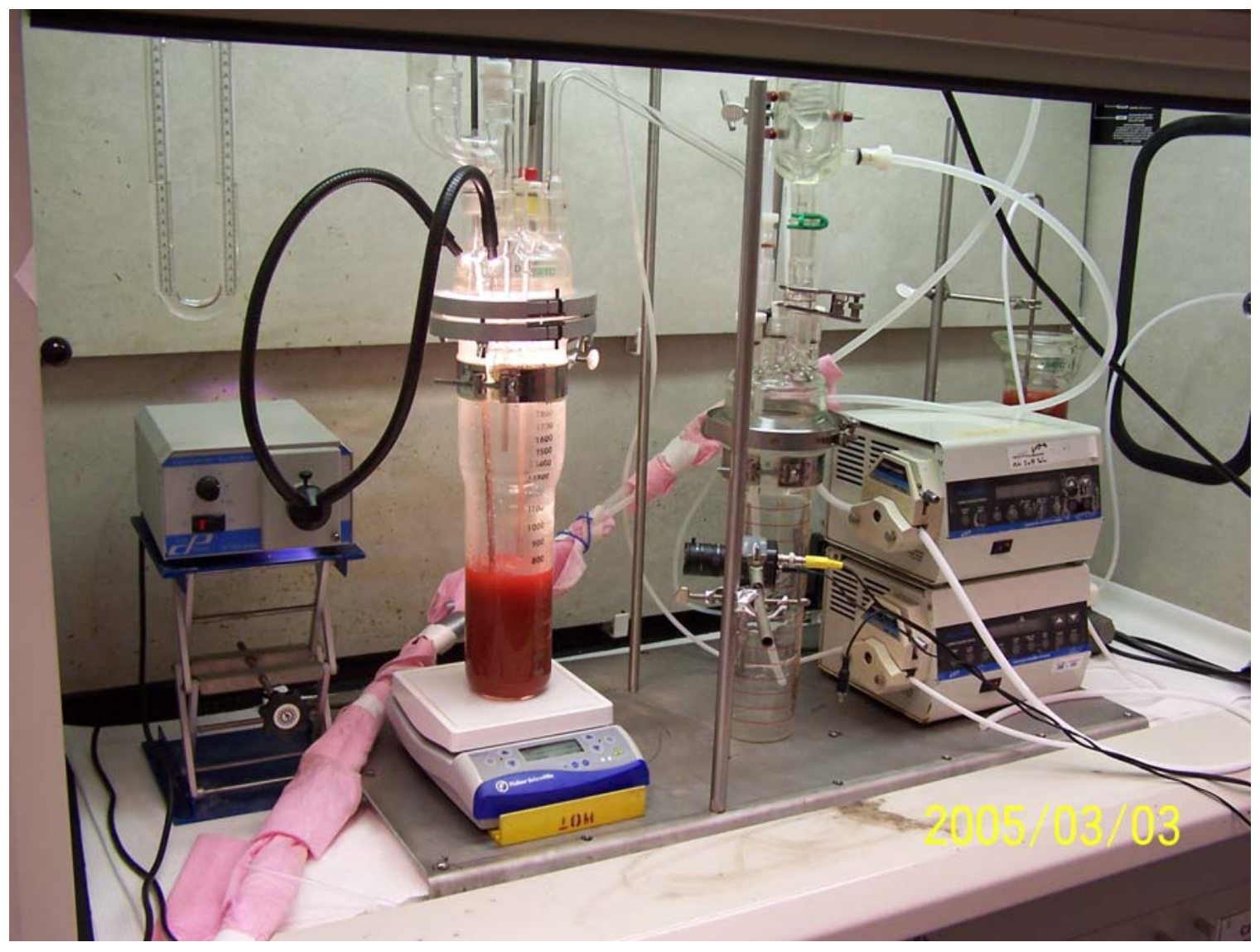

Figure B-4. Antifoam Evaporator Photograph 
1) Ensure rig has been assembled and leaked checked.

2) Ensure that feed pump has been checked per instructions from PI or alternate.

3) Ensure that all M\&TE to be utilized is recorded in laboratory notebook and Usage Log for the lab module.

4) Ensure that water bath contains adequate water and start bath with a temperature setpoint of $10^{\circ}$ C.

5) Verify that water bath hoses and fittings are not leaking.

6) Charge evaporator vessel with approximately $130 \mathrm{ml}$ of feed solution.

7) Start air purge at $50 \mathrm{ml} / \mathrm{min}$.

8) Begin stirring as specified by Principle Investigator.

9) Ensure pressure and temperature indication are operating.

10) Turn on hotplate and adjust power to 500 watts.

11) Record time that vessel reaches boiling.

12) When vessel volume decreases to $100 \mathrm{ml}$, start feed pump at $2.9 \mathrm{ml} / \mathrm{min}$.

13) Adjust feed rate as required to maintain $100 \mathrm{ml}$ in evaporator vessel.

14) Condensate should be removed from the condensate collection vessel as required to prevent overfilling. The condensate collection tank should be emptied as much as possible during each transfer. Care should be taken to avoid removal of any solids that may accumulate on the bottom of the vessel. The condensate should be placed in a tared polybottle and kept separate from condensate removed at different times. The condensate removed should be weighed and labeled "DWPF Recycle Evaporator Condensate- Scenario 1" along with sample time.

15) When 3 liters have been fed, the feed rate should be increased and concentrate removal started via the sampler as specified by the PI. The feed rate increase and concentrate removal rate will be calculated based on the boilup rate achieved during the test.

16) The feed solution should be transferred to smaller bottles as required to allow all the contents to be fed to the evaporator.

17) When the feed is exhausted, the run should be stopped by turning off the hotplate.

18) When the evaporator contents have cooled to $50^{\circ} \mathrm{C}$, then all equipment can be turned off.

19) The evaporator contents should be placed in the concentrate collection bottle. This bottle should be labeled with REBT-0011, date, researcher name, "DWPF Recycle Evaporator ConcentrateScenario 1".

20) The condensate in the collection vessel should be collected and labeled with REBT-0010, date, researcher name, "DWPF Recycle Evaporator Condensate- Scenario 1".

21) All offgas components should be visually inspected for elemental mercury. 
Operating Steps for Antifoam Tests

1) Ensure rig has been assembled and leak checked.

2) Ensure that all M\&TE to be utilized is recorded in laboratory notebook and Usage Log for the lab module.

3) Ensure that water bath contains adequate water and start bath with a temperature setpoint of $10^{\circ}$ C.

4) Verify that water bath hose and fitting are not leaking.

5) Charge evaporator vessel with $700 \mathrm{ml}$ of feed solution.

6) Begin stirring as specified by Principle Investigator (PI). Record final speed of mixer.

7) Charge vessel with 7 grams of the 2210 antifoam (1000 ppm).

8) Rinse antifoam addition funnel with 10 grams of DI water.

9) Turn on digital hotplate with a setpoint of $500^{\circ} \mathrm{C}$ and turn on heating coil to 600 watts.

10) Record time that vessel reaches boiling.

11) Record foam height and condensate amount every minute during the run until directed by PI to reduce recording to once every 5 minutes.

12) Add additional antifoam to vessel as directed by the PI.

13) Dewater $400 \mathrm{ml}$ of condensate.

14) When dewater is complete, turn off hot plate and heating coil.

15) Allow vessel to cool to $50^{\circ} \mathrm{C}$. 
WSRC-TR-2005-00142

Revision 0

\section{APPENDIX C. SAMPLE RESULTS FROM BOIL-DOWN TESTS}

Table C-1. Sample Results from Feed Slurries

\begin{tabular}{|c|c|c|c|c|c|c|c|c|c|}
\hline Sample ID & & $\begin{array}{c}\text { REBT } \\
0009 \\
\end{array}$ & $\begin{array}{c}\text { REBT } \\
0027\end{array}$ & $\begin{array}{c}\text { REBT } \\
0030 \\
\end{array}$ & $\begin{array}{c}\text { REBT } \\
0012 \\
\end{array}$ & $\begin{array}{c}\text { REBT } \\
0015 \\
\end{array}$ & $\begin{array}{c}\text { REBT } \\
0018 \\
\end{array}$ & $\begin{array}{c}\text { REBT } \\
0021 \\
\end{array}$ & $\begin{array}{l}\text { REBT } \\
0024 \\
\end{array}$ \\
\hline Description & Units & $\begin{array}{l}\text { Scenario } \\
1-1 \text { Feed }\end{array}$ & $\begin{array}{l}\text { Scenario } \\
1-2 \text { Feed }\end{array}$ & $\begin{array}{l}\text { Scenario } \\
1-3 \text { Feed }\end{array}$ & $\begin{array}{l}\text { Scenario } \\
2 \text { Feed }\end{array}$ & $\begin{array}{l}\text { Scenario } \\
3 \text { Feed }\end{array}$ & $\begin{array}{l}\text { Scenario } \\
4 \text { Feed }\end{array}$ & $\begin{array}{l}\text { Scenario } \\
5 \text { Feed }\end{array}$ & $\begin{array}{c}\text { Scenario } \\
6 \text { Feed }\end{array}$ \\
\hline $\mathrm{Ag}$ & $\mathrm{mg} / \mathrm{L}$ & & & & & & & 0.415 & \\
\hline $\mathrm{Al}$ & $\mathrm{mg} / \mathrm{L}$ & 10 & 9.37 & 8.135 & 15.4 & 0.507 & 52.9 & 225.5 & 4.61 \\
\hline B & $\mathrm{mg} / \mathrm{L}$ & 12.18 & 1.535 & 0.7685 & 6.445 & 4.22 & 92.45 & 5.425 & 1.525 \\
\hline $\mathrm{Ba}$ & $\mathrm{mg} / \mathrm{L}$ & 0.479 & & & 0.5475 & & & 5.315 & \\
\hline $\mathrm{Ca}$ & $\mathrm{mg} / \mathrm{L}$ & 15.9 & 16.4 & 16.2 & 9.685 & 23.85 & 106 & 162.5 & 8.46 \\
\hline $\mathrm{Cr}$ & $\mathrm{mg} / \mathrm{L}$ & & & & & & & 0.4145 & \\
\hline $\mathrm{Cu}$ & $\mathrm{mg} / \mathrm{L}$ & 0.2665 & 0.442 & 0.373 & 0.498 & & 0.3025 & 8.865 & 0.1695 \\
\hline $\mathrm{Fe}$ & $\mathrm{mg} / \mathrm{L}$ & 1070 & 841 & 870.5 & 106.5 & 1280 & 652.5 & 1870 & 393.5 \\
\hline $\mathrm{Gd}$ & $\mathrm{mg} / \mathrm{L}$ & & & & & & & 4.545 & \\
\hline K & $\mathrm{mg} / \mathrm{L}$ & 5.585 & 2.58 & 2.555 & 2.83 & 2.19 & 36.4 & 13.2 & 2.405 \\
\hline $\mathrm{Li}$ & $\mathrm{mg} / \mathrm{L}$ & & & & & & & 9.03 & \\
\hline $\mathrm{Mg}$ & $\mathrm{mg} / \mathrm{L}$ & 31.15 & 31.8 & 31.5 & 10.1 & 55.5 & 52.15 & 218 & 15.35 \\
\hline $\mathrm{Mn}$ & $\mathrm{mg} / \mathrm{L}$ & 62.15 & 63.35 & 64 & 19.5 & 121.5 & 45.45 & 372.5 & 32.35 \\
\hline Mo & $\mathrm{mg} / \mathrm{L}$ & 0.1515 & 1.59 & 0.858 & 0.7535 & 1.32 & 4.015 & 0.6 & 1.525 \\
\hline $\mathrm{Na}$ & $\mathrm{mg} / \mathrm{L}$ & 148 & 127.5 & 137.5 & 61.2 & 2065 & 9270 & 1215 & 60.7 \\
\hline $\mathrm{Ni}$ & $\mathrm{mg} / \mathrm{L}$ & 18.5 & 14.65 & 13.55 & 3.57 & 31.05 & 13.35 & 66.5 & 5.675 \\
\hline $\mathrm{P}$ & $\mathrm{mg} / \mathrm{L}$ & & & & 0.3615 & & & 2.83 & \\
\hline $\mathrm{Pb}$ & $\mathrm{mg} / \mathrm{L}$ & & & & & & & 4.88 & \\
\hline S & $\mathrm{mg} / \mathrm{L}$ & 9.925 & 10.2 & 10.01 & 49.95 & 19.55 & 8.83 & 30.05 & 5.205 \\
\hline $\mathrm{Sb}$ & $\mathrm{mg} / \mathrm{L}$ & 1.695 & 1.795 & & & & & & \\
\hline $\mathrm{Si}$ & $\mathrm{mg} / \mathrm{L}$ & 30.25 & 77.3 & 78.65 & 58.05 & 5.415 & 176 & 17.35 & 41.6 \\
\hline $\mathrm{Ti}$ & $\mathrm{mg} / \mathrm{L}$ & & & & & & & 0.612 & \\
\hline $\mathrm{Zn}$ & $\mathrm{mg} / \mathrm{L}$ & 0.134 & & & 0.4705 & & & 15.4 & \\
\hline $\mathrm{Zr}$ & $\mathrm{mg} / \mathrm{L}$ & & & & & & 0.6685 & 0.301 & \\
\hline $\mathrm{NO} 3$ & $\mathrm{mg} / \mathrm{L}$ & 3880 & 3657.5 & 3862 & 5465 & 1605 & 23935 & 7675 & 1886.5 \\
\hline $\mathrm{PO} 4$ & $\mathrm{mg} / \mathrm{L}$ & & & & & & & & \\
\hline $\mathrm{SO} 4$ & $\mathrm{mg} / \mathrm{L}$ & 487 & 360.5 & 379.5 & 165.5 & 1300 & 196 & 815 & 212.5 \\
\hline $\mathrm{HCO} 2$ & $\mathrm{mg} / \mathrm{L}$ & 380.5 & & & 654.5 & & & 4195 & \\
\hline $\mathrm{Hg}$ & $\mathrm{mg} / \mathrm{kg}$ & 159 & 151 & 201 & 146 & 159 & 119 & 107 & 76.1 \\
\hline Slurry Density & $\mathrm{g} / \mathrm{ml}$ & 1.0012 & 1.00127 & 1.001335 & 1.00095 & 1.000795 & 1.023775 & 1.007955 & 0.99515 \\
\hline $\begin{array}{c}\text { Supernate } \\
\text { Density }\end{array}$ & $\mathrm{g} / \mathrm{ml}$ & 1.00026 & 1.00025 & 1.00026 & 1.000855 & 0.99949 & 1.0215 & 1.00506 & 0.99905 \\
\hline Total Solids & wt $\%$ & 0.27 & 0.14 & 0.34 & 0.16 & 0.36 & 3.85 & 1.31 & 0.04 \\
\hline Soluble Solids & wt $\%$ & 0.1 & 0.11 & 0.09 & 0.04 & 0.06 & 3.44 & 0.78 & 0.06 \\
\hline Insoluble Solids & wt $\%$ & 0.17 & 0.03 & 0.25 & 0.12 & 0.29 & 0.41 & 0.53 & 0 \\
\hline $\mathrm{pH}$ & & 1.29 & 1.34 & 1.31 & 1.02 & 2.1 & 1.6 & 1.91 & 1.64 \\
\hline Titration & Molar & 0.048 & 0.047 & 0.049 & 0.078 & 0.010 & 0.028 & 0.071 & 0.023 \\
\hline $\begin{array}{l}\text { Supernate } \\
\text { Viscosity }\end{array}$ & $\mathrm{cP}$ & 0.884 & 0.894 & 0.888 & 0.885 & 0.871 & 0.904 & 0.893 & 0.895 \\
\hline
\end{tabular}

Note: Blanks indicate less than detectable amounts in sample. Detection limits shown in Table F-1. 
WSRC-TR-2005-00142

Revision 0

Table C-2. Sample Results from Condensates

\begin{tabular}{|c|c|c|c|c|c|c|c|c|c|c|}
\hline Sample ID & Units & $\begin{array}{l}\text { WAC } \\
\text { Limits }\end{array}$ & $\begin{array}{c}\text { REBT } \\
0010 \\
\end{array}$ & $\begin{array}{c}\text { REBT } \\
0028 \\
\end{array}$ & $\begin{array}{c}\text { REBT } \\
0031 \\
\end{array}$ & $\begin{array}{c}\text { REBT } \\
0013 \\
\end{array}$ & $\begin{array}{c}\text { REBT } \\
0016 \\
\end{array}$ & $\begin{array}{c}\text { REBT } \\
0019 \\
\end{array}$ & $\begin{array}{c}\text { REBT } \\
0022 \\
\end{array}$ & $\begin{array}{c}\text { REBT } \\
0025 \\
\end{array}$ \\
\hline Description & & & $\begin{array}{c}\text { Scenario } \\
1-1 \\
\end{array}$ & $\begin{array}{c}\text { Scenario } \\
1-2 \\
\end{array}$ & $\begin{array}{c}\text { Scenario } \\
1-3 \\
\end{array}$ & $\begin{array}{c}\text { Scenario } \\
2 \\
\end{array}$ & $\begin{array}{c}\text { Scenario } \\
3 \\
\end{array}$ & $\begin{array}{c}\text { Scenario } \\
4 \\
\end{array}$ & $\begin{array}{c}\text { Scenario } \\
5 \\
\end{array}$ & $\begin{array}{c}\text { Scenario } \\
6 \\
\end{array}$ \\
\hline $\mathrm{Al}$ & $\mathrm{mg} / \mathrm{L}$ & 1080 & 0.0105 & 0.235 & 0.205 & & & 0.231 & & 0.2525 \\
\hline B & $\mathrm{mg} / \mathrm{L}$ & 6.92 & 0.9475 & 0.762 & 0.664 & 0.4205 & 0.254 & 16.45 & 0.2415 & 0.789 \\
\hline $\mathrm{Ca}$ & $\mathrm{mg} / \mathrm{L}$ & & 0.1445 & & & 0.027 & & & 0.058 & \\
\hline $\mathrm{Cr}$ & $\mathrm{mg} / \mathrm{L}$ & 8.40 & & & & & & & & 2.64 \\
\hline $\mathrm{K}$ & $\mathrm{mg} / \mathrm{L}$ & & 0.2515 & 0.2325 & 0.2315 & 0.2235 & 0.1775 & 0.235 & 0.1765 & 0.539 \\
\hline $\mathrm{Mn}$ & $\mathrm{mg} / \mathrm{L}$ & 6.92 & & & & & & & 0.0535 & \\
\hline Mo & $\mathrm{mg} / \mathrm{L}$ & & 0.061 & 0.067 & 0.058 & 0.0505 & 0.057 & 0.091 & 0.048 & 0.067 \\
\hline $\mathrm{Na}$ & $\mathrm{mg} / \mathrm{L}$ & 1240 & & 0.3945 & 0.62 & & & 0.5865 & & 0.3515 \\
\hline $\mathrm{S}$ & $\mathrm{mg} / \mathrm{L}$ & & & & & 0.2115 & & & & \\
\hline Si & $\mathrm{mg} / \mathrm{L}$ & 90.2 & 408 & 66.5 & 66.9 & 1120 & 0.2535 & 28.05 & 0.5285 & 9.41 \\
\hline & $\mathrm{mg} / \mathrm{L}$ & & & & & & & & & \\
\hline $\mathrm{NO} 3$ & $\mathrm{mg} / \mathrm{L}$ & 1180 & 428.5 & 284 & 420 & 702.5 & & 839.5 & 1080 & 172 \\
\hline $\mathrm{SO} 4$ & $\mathrm{mg} / \mathrm{L}$ & 133 & & 397.5 & 434 & & & 162.5 & 103 & 176.5 \\
\hline $\mathrm{HCO} 2$ & $\mathrm{mg} / \mathrm{L}$ & & 361 & & & 818.5 & & & 3015 & \\
\hline $\mathrm{Hg}$ & $\mathrm{mg} / \mathrm{kg}$ & 40.6 & 152 & 12 & 77.1 & 17.1 & 0 & 36.3 & 20 & 22.6 \\
\hline $\begin{array}{c}\text { Supernate } \\
\text { Density }\end{array}$ & $\mathrm{g} / \mathrm{ml}$ & & 0.99812 & 0.99806 & 0.99812 & 0.99828 & 0.99789 & 0.99828 & 0.99870 & 0.99800 \\
\hline Total Solids & wt $\%$ & & 0.02 & 0 & 0 & 0 & 0 & 0 & 0 & 0 \\
\hline $\mathrm{pH}$ & & & 2.2 & 2.42 & 2.27 & 1.92 & 3.01 & 1.95 & 3.01 & 2.46 \\
\hline Titration & Molar & & $\mathrm{nm}$ & $\mathrm{nm}$ & $\mathrm{nm}$ & $\mathrm{nm}$ & $\mathrm{nm}$ & 0.01 & $\mathrm{~nm}$ & $\mathrm{~nm}$ \\
\hline $\begin{array}{c}\text { Supernate } \\
\text { Viscosity }\end{array}$ & $\mathrm{CP}$ & & $\mathrm{nm}$ & $\mathrm{nm}$ & $\mathrm{nm}$ & $\mathrm{nm}$ & $\mathrm{nm}$ & 0.890 & $\mathrm{~nm}$ & 0.897 \\
\hline
\end{tabular}

Note: Blanks indicate less than detectable amounts in sample. Detection limits shown in Table

F-1. "nm" indicates not measured. 
WSRC-TR-2005-00142

Revision 0

Table C-3. Sample Results from Concentrates

\begin{tabular}{|c|c|c|c|c|c|c|c|c|}
\hline Sample ID & Units & $\begin{array}{c}\text { REBT } \\
0011 \\
\end{array}$ & $\begin{array}{c}\text { REBT } \\
0029 \\
\end{array}$ & $\begin{array}{l}\text { REBT } \\
0032 \\
\end{array}$ & $\begin{array}{c}\text { REBT } \\
0014 \\
\end{array}$ & $\begin{array}{c}\text { REBT } \\
0017 \\
\end{array}$ & $\begin{array}{c}\text { REBT } \\
0023 \\
\end{array}$ & $\begin{array}{c}\text { REBT } \\
0026 \\
\end{array}$ \\
\hline Description & & $\begin{array}{c}\text { Scenario } \\
1-1\end{array}$ & $\begin{array}{c}\text { Scenario } \\
1-2 \\
\end{array}$ & $\begin{array}{c}\text { Scenario } \\
1-3\end{array}$ & $\begin{array}{c}\text { Scenario } \\
2\end{array}$ & $\begin{array}{c}\text { Scenario } \\
3\end{array}$ & $\begin{array}{c}\text { Scenario } \\
5\end{array}$ & $\begin{array}{c}\text { Scenario } \\
6\end{array}$ \\
\hline $\mathrm{Ag}$ & $\mathrm{mg} / \mathrm{L}$ & 0.625 & 0.9185 & 0.769 & 1.16 & & 44.8 & 0.5555 \\
\hline $\mathrm{Al}$ & $\mathrm{mg} / \mathrm{L}$ & 555 & 330 & 496.5 & 655.5 & 47.7 & 5275 & 367.5 \\
\hline $\mathrm{B}$ & $\mathrm{mg} / \mathrm{L}$ & 18.65 & 3.3 & 2.585 & 8.49 & 23.75 & 105 & 2.715 \\
\hline $\mathrm{Ba}$ & $\mathrm{mg} / \mathrm{L}$ & 8.635 & 8.84 & 9.74 & 15.55 & & 114 & 7.34 \\
\hline $\mathrm{Ca}$ & $\mathrm{mg} / \mathrm{L}$ & 463.5 & 467 & 552.5 & 288 & 622.5 & 4535 & 433.5 \\
\hline $\mathrm{Ce}$ & $\mathrm{mg} / \mathrm{L}$ & 0.139 & & & & 0.4595 & 4.1 & \\
\hline $\mathrm{Cr}$ & $\mathrm{mg} / \mathrm{L}$ & 1.455 & 3.47 & 2.965 & 1.88 & 0.7765 & 7.545 & \\
\hline $\mathrm{Cu}$ & $\mathrm{mg} / \mathrm{L}$ & 11.6 & 12.5 & 13.5 & 19.2 & 0.1775 & 279.5 & 9.915 \\
\hline $\mathrm{Fe}$ & $\mathrm{mg} / \mathrm{L}$ & 26300 & 24150 & 32350 & 3320 & 41850 & 52250 & 24800 \\
\hline $\mathrm{Gd}$ & $\mathrm{mg} / \mathrm{L}$ & 8.055 & 8.1 & 9.825 & 7.975 & 5.995 & 147.5 & 7.56 \\
\hline $\mathrm{K}$ & $\mathrm{mg} / \mathrm{L}$ & 22 & 21.55 & 24.7 & 26.65 & 4.375 & 515.5 & 18.35 \\
\hline La & $\mathrm{mg} / \mathrm{L}$ & & & & & 0.3085 & 1.155 & \\
\hline $\mathrm{Li}$ & $\mathrm{mg} / \mathrm{L}$ & 6.62 & 4.645 & 5.1 & 6.32 & & 319.5 & 3.505 \\
\hline $\mathrm{Mg}$ & $\mathrm{mg} / \mathrm{L}$ & 830.5 & 834.5 & 958 & 316 & 1335 & 6600 & 831 \\
\hline $\mathrm{Mn}$ & $\mathrm{mg} / \mathrm{L}$ & 1865 & 1870 & 2195 & 581 & 2750 & 12450 & 1885 \\
\hline Mo & $\mathrm{mg} / \mathrm{L}$ & 0.705 & 1.0145 & 0.7155 & 0.732 & 0.6245 & 0.8205 & 1.07 \\
\hline $\mathrm{Na}$ & $\mathrm{mg} / \mathrm{L}$ & 3515 & 3770 & 4385 & 2025 & 4970 & 35800 & 3455 \\
\hline $\mathrm{Ni}$ & $\mathrm{mg} / \mathrm{L}$ & 583 & 195 & 529 & 126 & 1085 & 1565 & 282.5 \\
\hline $\mathrm{P}$ & $\mathrm{mg} / \mathrm{L}$ & 6.03 & 5.205 & 5.33 & 10.15 & & 81.85 & 3.995 \\
\hline $\mathrm{Pb}$ & $\mathrm{mg} / \mathrm{L}$ & 6.715 & 6.765 & 7.625 & 11.2 & 2.27 & 156 & 5.89 \\
\hline $\mathrm{s}$ & $\mathrm{mg} / \mathrm{L}$ & 300.5 & 295 & 361 & 61.1 & 538 & 918.5 & 288.5 \\
\hline $\mathrm{Sb}$ & $\mathrm{mg} / \mathrm{L}$ & 5.725 & & & & & & \\
\hline $\mathrm{Si}$ & $\mathrm{mg} / \mathrm{L}$ & 263 & 294.5 & 344 & 251.5 & 16.1 & 75.8 & 276 \\
\hline Sn & $\mathrm{mg} / \mathrm{L}$ & & & 0.763 & & & 5.08 & 0.7035 \\
\hline $\mathrm{Sr}$ & $\mathrm{mg} / \mathrm{L}$ & 1.285 & 1.185 & 1.225 & 1.115 & 1.08 & 8.895 & 1.13 \\
\hline $\mathrm{Ti}$ & $\mathrm{mg} / \mathrm{L}$ & 1.48 & 1.49 & 1.74 & 2.715 & & 22.3 & 1.175 \\
\hline $\mathrm{Zn}$ & $\mathrm{mg} / \mathrm{L}$ & 26.3 & 24.6 & 29.6 & 38.25 & 8.425 & 486.5 & 21.7 \\
\hline $\mathrm{Zr}$ & $\mathrm{mg} / \mathrm{L}$ & 0.462 & 3.26 & 3.02 & 0.5455 & 0.6915 & 2.685 & 2.23 \\
\hline $\mathrm{F}$ & $\mathrm{mg} / \mathrm{L}$ & & & & & & 231.5 & \\
\hline $\mathrm{NO} 2$ & $\mathrm{mg} / \mathrm{L}$ & & & & & & 182 & \\
\hline $\mathrm{NO} 3$ & $\mathrm{mg} / \mathrm{L}$ & 109500 & 100500 & 119600 & 183000 & 40650 & 209000 & 95280 \\
\hline $\mathrm{SO} 4$ & $\mathrm{mg} / \mathrm{L}$ & 1450 & 355 & 470.5 & 3425 & 1675 & 1295 & 221 \\
\hline $\mathrm{HCO} 2$ & $\mathrm{mg} / \mathrm{L}$ & 392.5 & & & 852 & & 3205 & \\
\hline $\mathrm{Hg}$ & $\mathrm{mg} / \mathrm{kg}$ & 2480 & 2980 & 3380 & 2780 & 3930 & 77 & 2460 \\
\hline Slurry Density & $\mathrm{g} / \mathrm{ml}$ & 1.09455 & 1.088335 & 1.1119 & 1.08455 & 1.096055 & 1.255955 & 1.09363 \\
\hline $\begin{array}{c}\text { Supernate } \\
\text { Density }\end{array}$ & $\mathrm{g} / \mathrm{ml}$ & 1.06686 & 1.06711 & 1.07693 & 1.08406 & 1.0387 & 1.1762 & 1.06477 \\
\hline Total Solids & wt \% & 8.73 & 7.18 & 9.13 & 3.37 & 11.14 & 28.71 & 7.71 \\
\hline Soluble Solids & wt \% & 4.43 & 4.2 & 4.72 & 3.3 & 4.53 & 21.04 & 4.09 \\
\hline Insoluble Solids & wt \% & 4.3 & 2.97 & 4.41 & 0.07 & 6.61 & 7.67 & 3.62 \\
\hline $\mathrm{pH}$ & & 2.68 & 2.65 & 2.58 & 2.33 & 0.71 & 2.6 & 2.76 \\
\hline Titration & molar & 1.12 & 1.16 & 1.36 & 2.05 & 0.20 & 0.21 & 1.16 \\
\hline $\begin{array}{l}\text { Supernate } \\
\text { Viscosity }\end{array}$ & $\mathrm{cP}$ & 1.021 & 1.029 & 1.035 & 1.045 & 0.939 & 1.387 & 1.022 \\
\hline
\end{tabular}

Note: Blanks indicate less than detectable amounts in sample. Detection limits shown in Table F-1. 
WSRC-TR-2005-00142

Revision 0

Table C-4. Concentration Factors for Each Scenario

\begin{tabular}{|c|c|c|c|c|c|c|c|}
\hline Element & $\begin{array}{c}\text { Scenario } \\
1-1\end{array}$ & $\begin{array}{c}\text { Scenario } \\
1-2\end{array}$ & $\begin{array}{c}\text { Scenario } \\
1-3\end{array}$ & $\begin{array}{c}\text { Scenario } \\
2\end{array}$ & $\begin{array}{c}\text { Scenario } \\
3\end{array}$ & $\begin{array}{c}\text { Scenario } \\
5\end{array}$ & $\begin{array}{c}\text { Scenario } \\
6\end{array}$ \\
\hline $\mathrm{Al}$ & 55.5 & 35.2 & 61.0 & 42.6 & 94.1 & 23.4 & 79.7 \\
\hline $\mathrm{B}$ & 1.5 & 2.1 & 3.4 & 1.3 & 5.6 & 19.4 & 1.8 \\
\hline $\mathrm{Ba}$ & 18.0 & & & 28.4 & & & \\
\hline $\mathrm{Ca}$ & 29.2 & 28.5 & 34.1 & 29.7 & 26.1 & 27.9 & 51.2 \\
\hline $\mathrm{Cr}$ & & & & & & 18.2 & \\
\hline $\mathrm{Cu}$ & 43.5 & 28.3 & 36.2 & 38.6 & & 31.5 & 58.5 \\
\hline $\mathrm{Fe}$ & 24.6 & 28.7 & 37.2 & 31.2 & 32.7 & 27.9 & 63.0 \\
\hline $\mathrm{Gd}$ & & & & & & 32.5 & \\
\hline $\mathrm{K}$ & 3.9 & 8.4 & 9.7 & 9.4 & 2.0 & 39.1 & 7.6 \\
\hline $\mathrm{Li}$ & & & & & & 35.4 & \\
\hline $\mathrm{Mg}$ & 26.7 & 26.2 & 30.4 & 31.3 & 24.1 & 30.3 & 54.1 \\
\hline $\mathrm{Mn}$ & 30.0 & 29.5 & 34.3 & 29.8 & 22.6 & 33.4 & 58.3 \\
\hline $\mathrm{Mo}$ & 4.7 & 0.6 & 0.8 & 1.0 & 0.5 & 1.4 & 0.7 \\
\hline $\mathrm{Na}$ & 23.8 & 29.6 & 31.9 & 33.1 & 2.4 & 29.5 & 56.9 \\
\hline $\mathrm{Ni}$ & 31.5 & 13.3 & 39.0 & 35.3 & 34.9 & 23.5 & 49.8 \\
\hline $\mathrm{P}$ & & & & 28.1 & & 28.9 & \\
\hline $\mathrm{Pb}$ & & & & & & 32.0 & \\
\hline $\mathrm{S}$ & 30.3 & 28.9 & 36.1 & 1.2 & 27.5 & 30.6 & 55.4 \\
\hline $\mathrm{Si}$ & 8.7 & 3.8 & 4.4 & 4.3 & 3.0 & 4.4 & 6.6 \\
\hline $\mathrm{Ti}$ & & & & & & 36.4 & \\
\hline $\mathrm{Zn}$ & 196.3 & & & 81.3 & & 31.6 & \\
\hline $\mathrm{NO} 3$ & 28.2 & 27.5 & 31.0 & 33.5 & 25.3 & 27.2 & 50.5 \\
\hline $\mathrm{SO} 4$ & 3.0 & 1.0 & 1.2 & 20.7 & 1.3 & 1.6 & 1.0 \\
\hline $\mathrm{HCO} 2$ & 1.0 & & & 1.3 & & 0.8 & \\
\hline $\mathrm{Hg}$ & 15.6 & 19.7 & 16.8 & 19.0 & 24.7 & 0.7 & 32.3 \\
\hline $\mathrm{K}$ & 2.0 & & & & & 3.8 & \\
\hline Total Solids & 32.3 & 51.3 & 26.9 & 21.1 & 30.9 & 21.9 & 192.8 \\
\hline Soluble Solids & 44.3 & 38.2 & 52.4 & 82.5 & 75.5 & 27.0 & 68.2 \\
\hline $\mathrm{Insoluble} \mathrm{Solids}$ & 25.3 & 99.0 & 17.6 & 0.6 & 22.8 & 14.5 & $\mathrm{~N} / \mathrm{A}$ \\
\hline & & & & & & & \\
\hline
\end{tabular}




\section{APPENDIX D. XRD RESULTS}

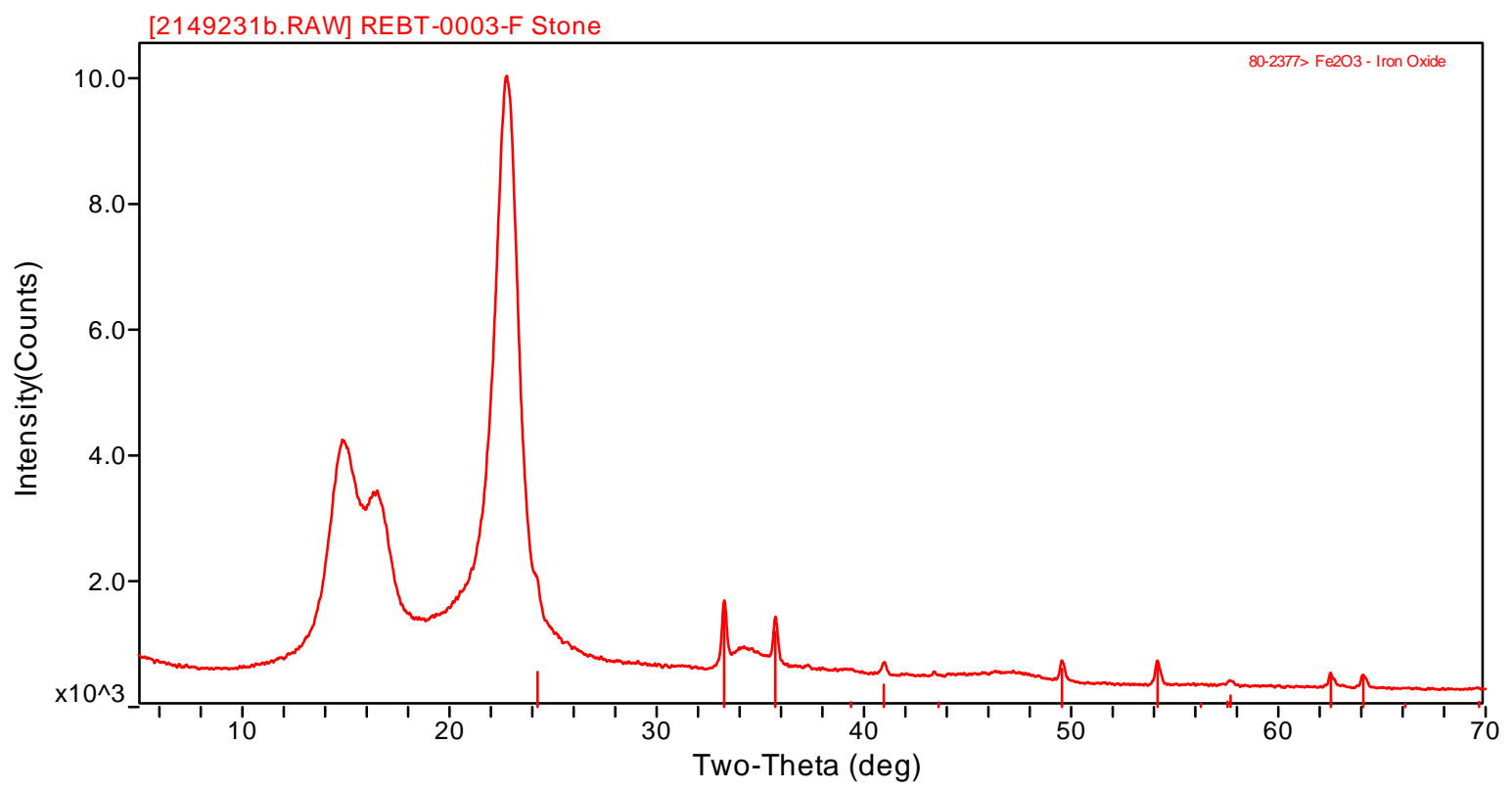

Figure D-1. OGCT Simulant XRD

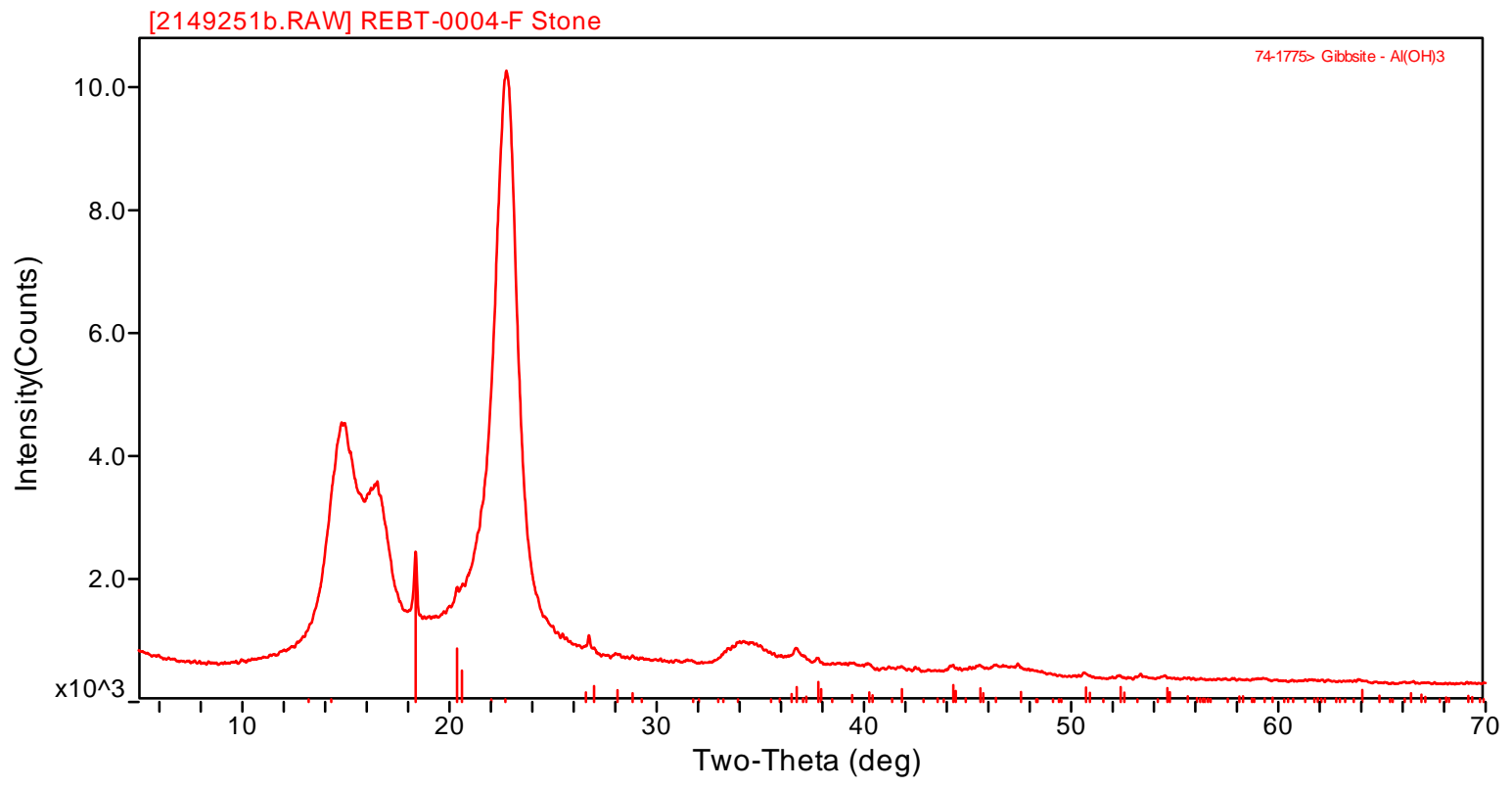

Figure D-2. Decon Solution Simulant XRD 
WSRC-TR-2005-00142

Revision 0

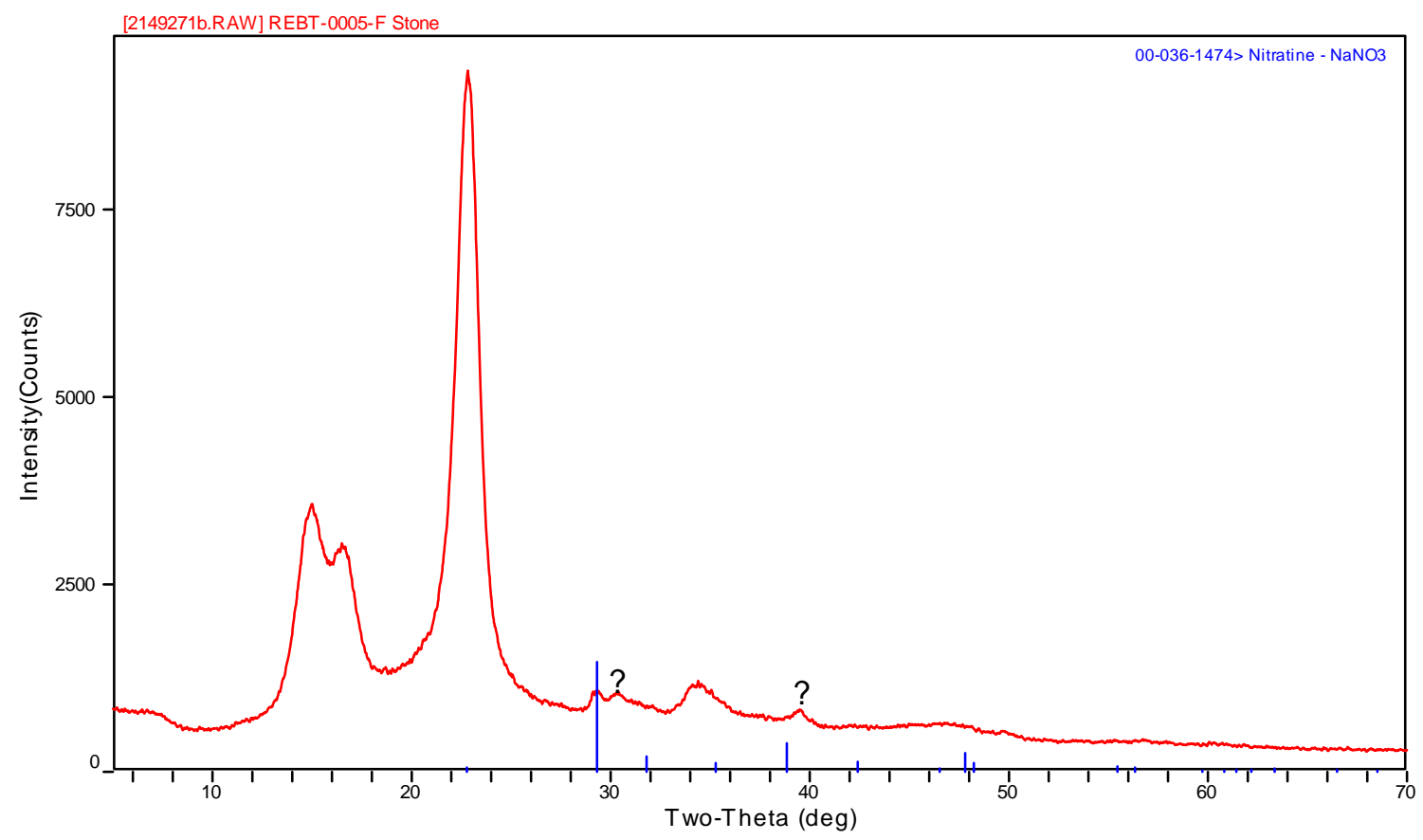

Figure D-3. HEME Dissolution Simulant XRD 


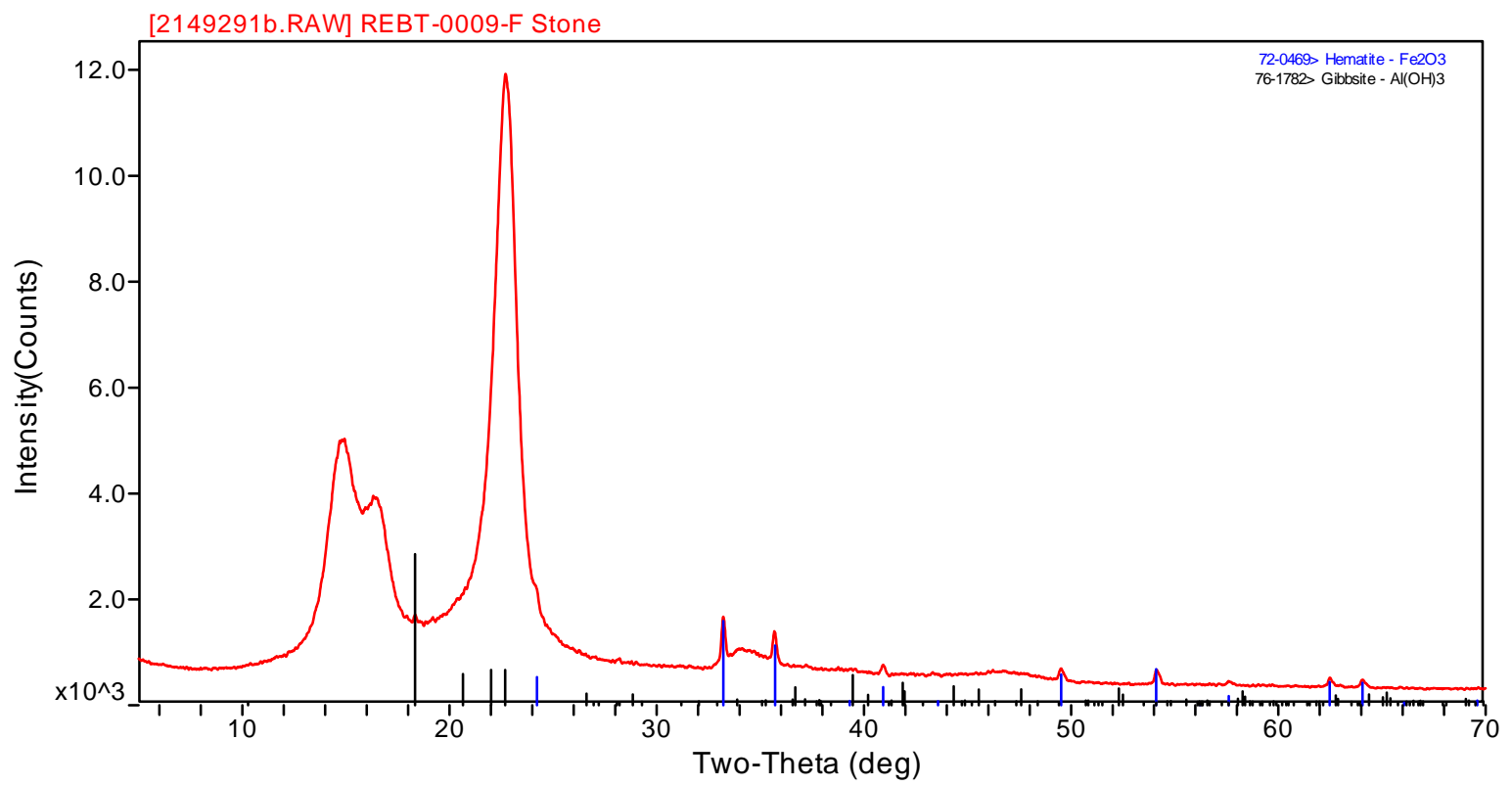

Figure D-4. Scenario 1-1 Feed XRD

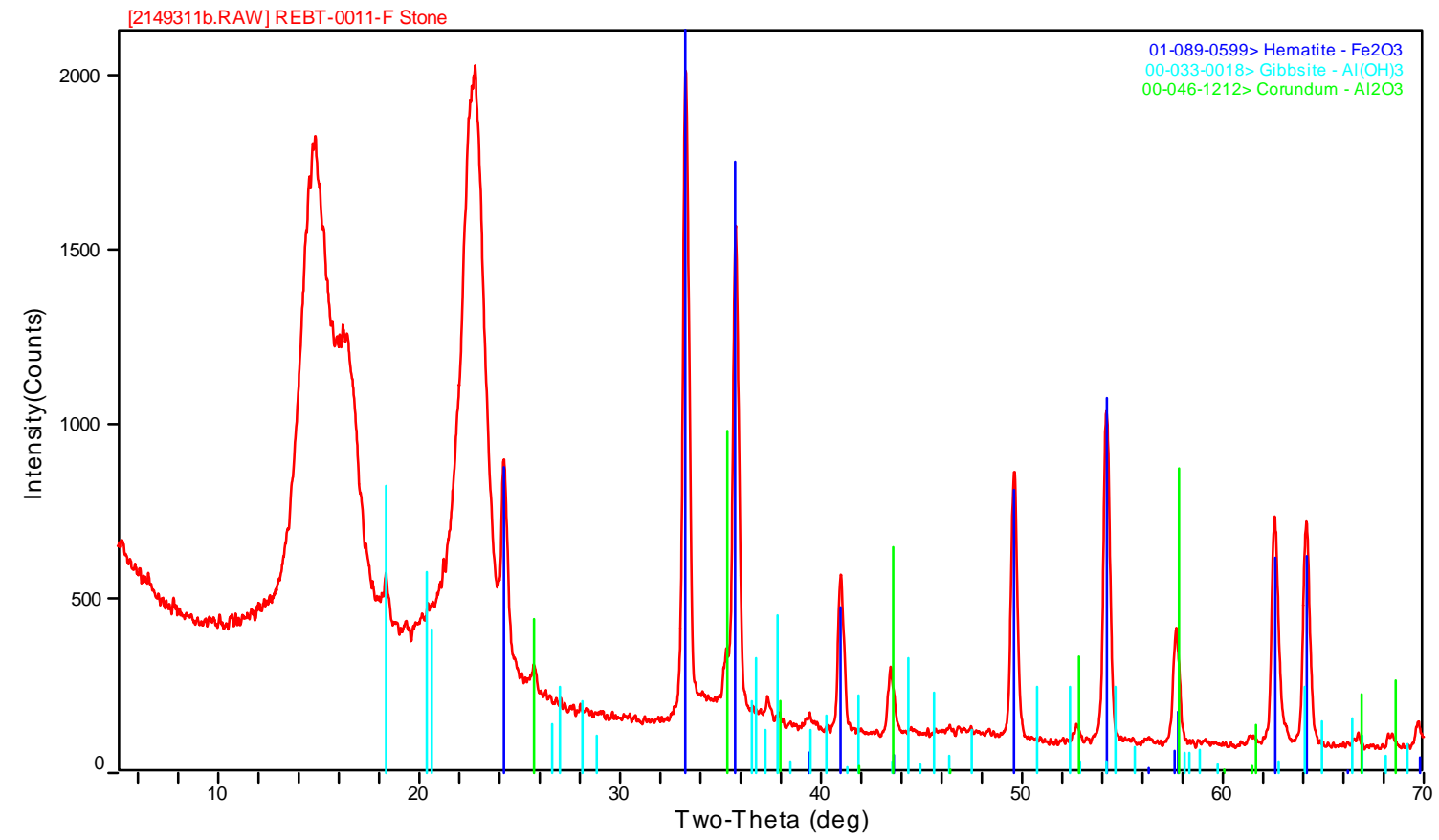

Figure D-5. Scenario 1-1 Concentrate XRD 
WSRC-TR-2005-00142

Revision 0

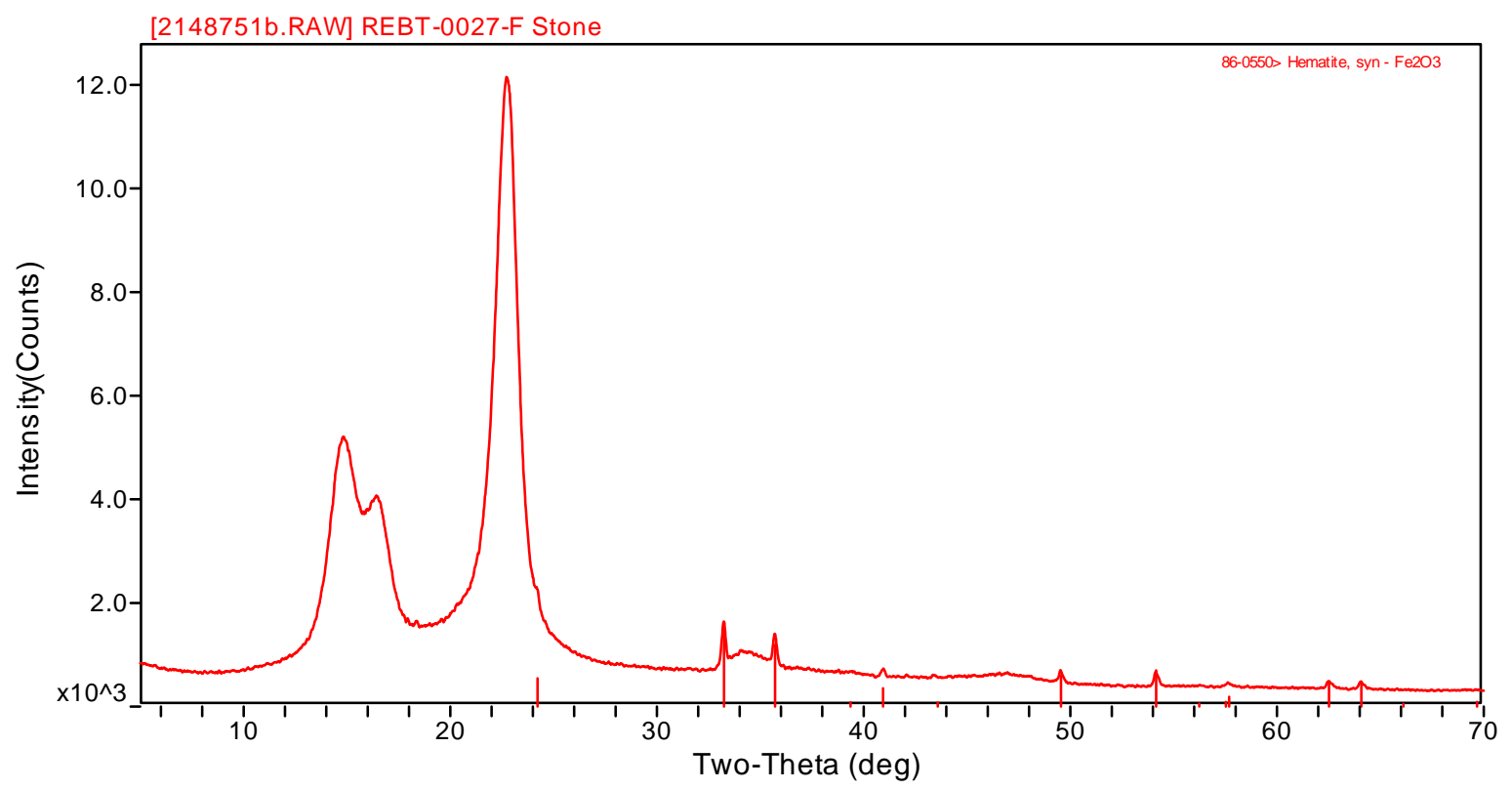

Figure D-6. Scenario 1-2 Feed XRD

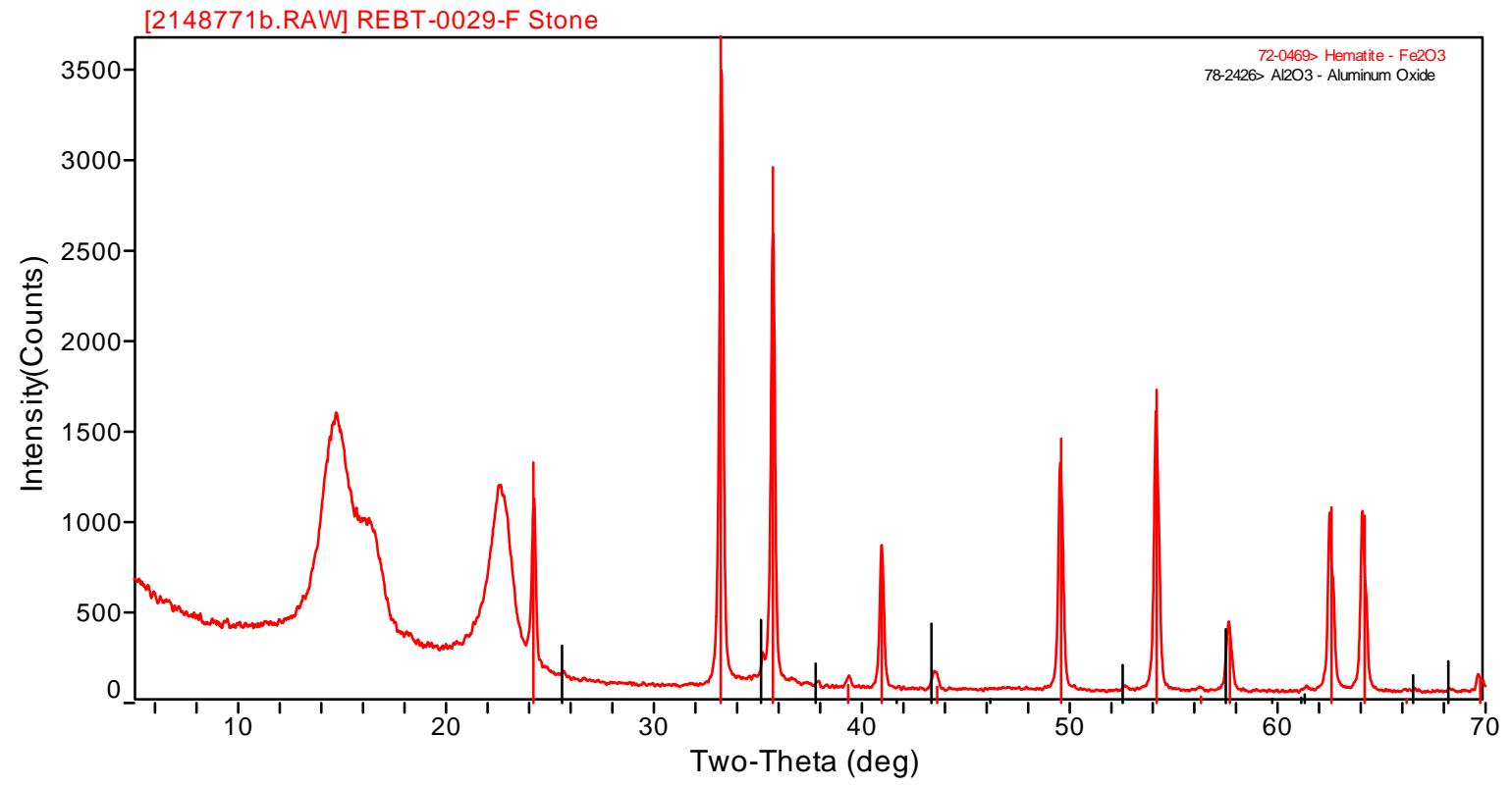

Figure D-7. Scenario 1-2 Concentrate XRD 
WSRC-TR-2005-00142

Revision 0

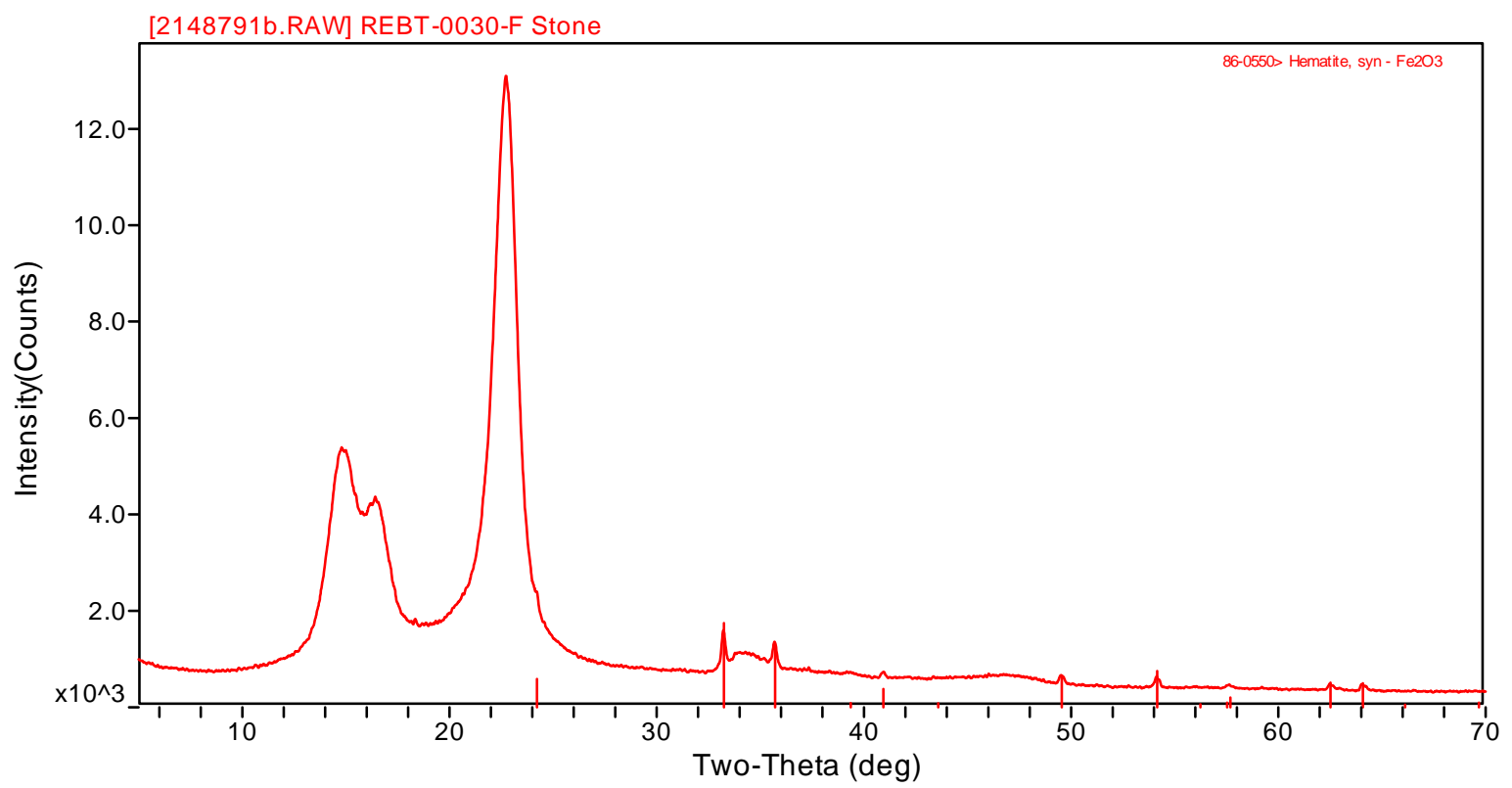

Figure D-8. Scenario 1-3 Feed XRD

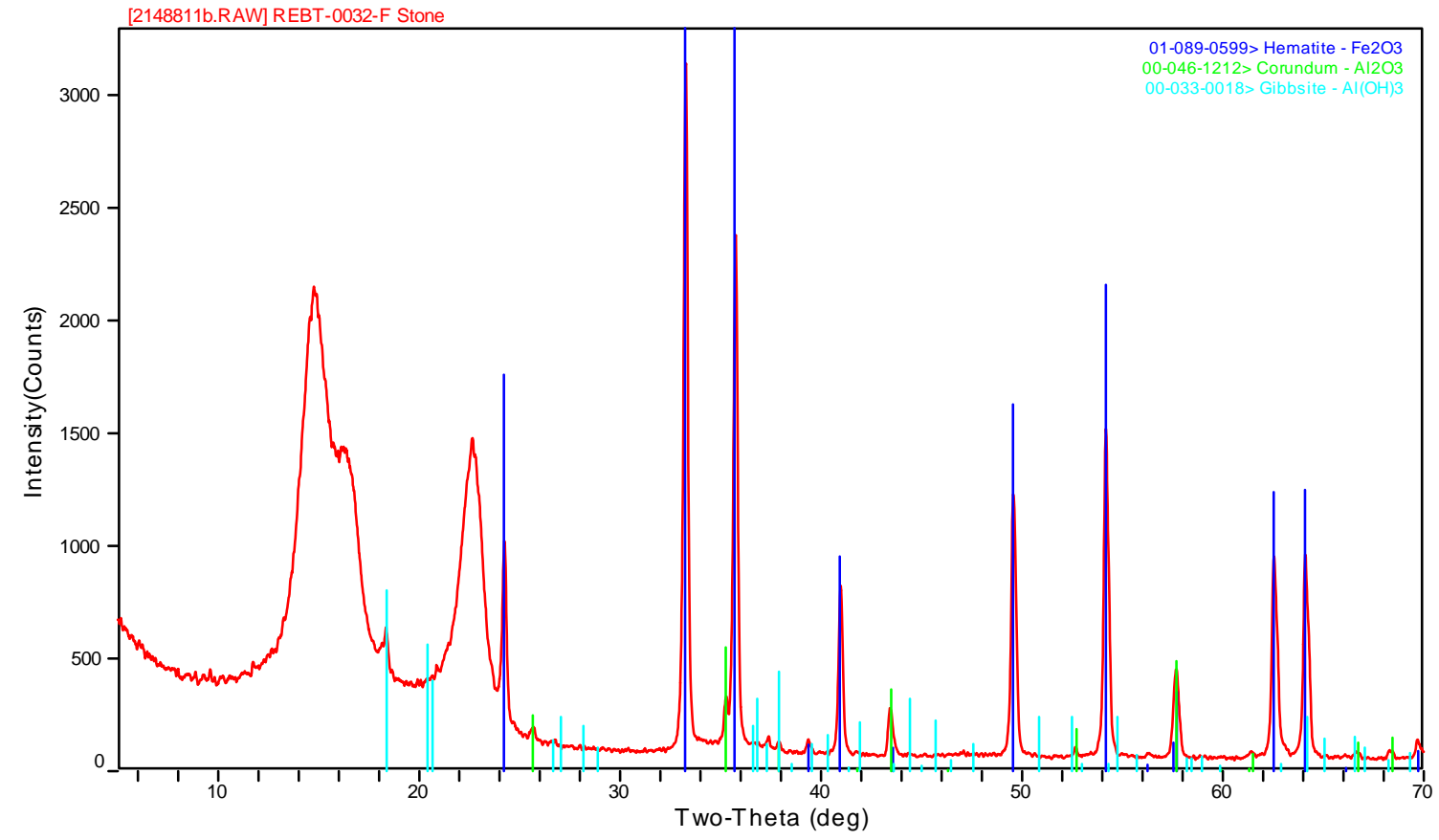

Figure D-9. Scenario 1-3 Concentrate XRD 
WSRC-TR-2005-00142

Revision 0

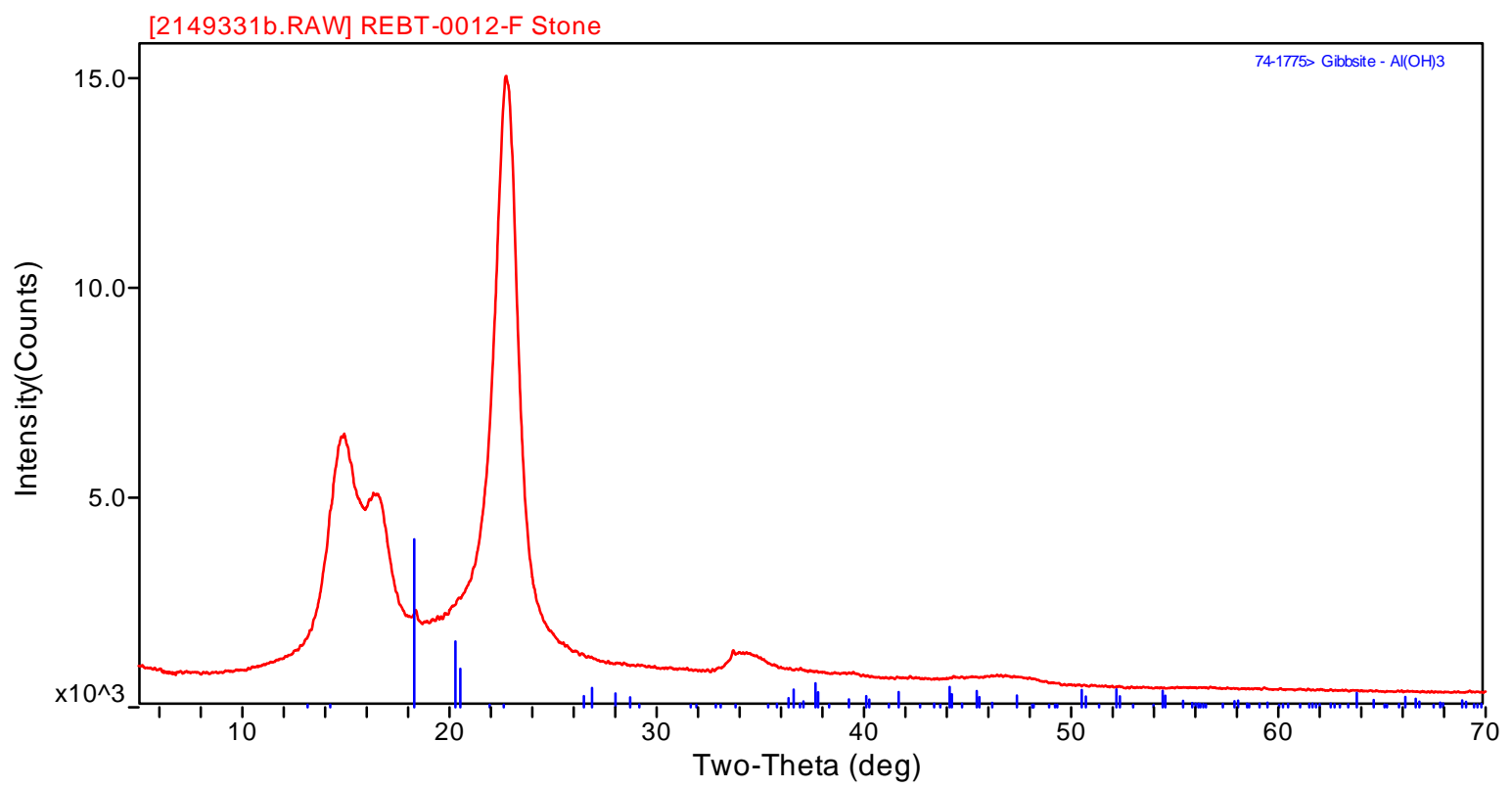

Figure D-10. Scenario 2 Feed XRD

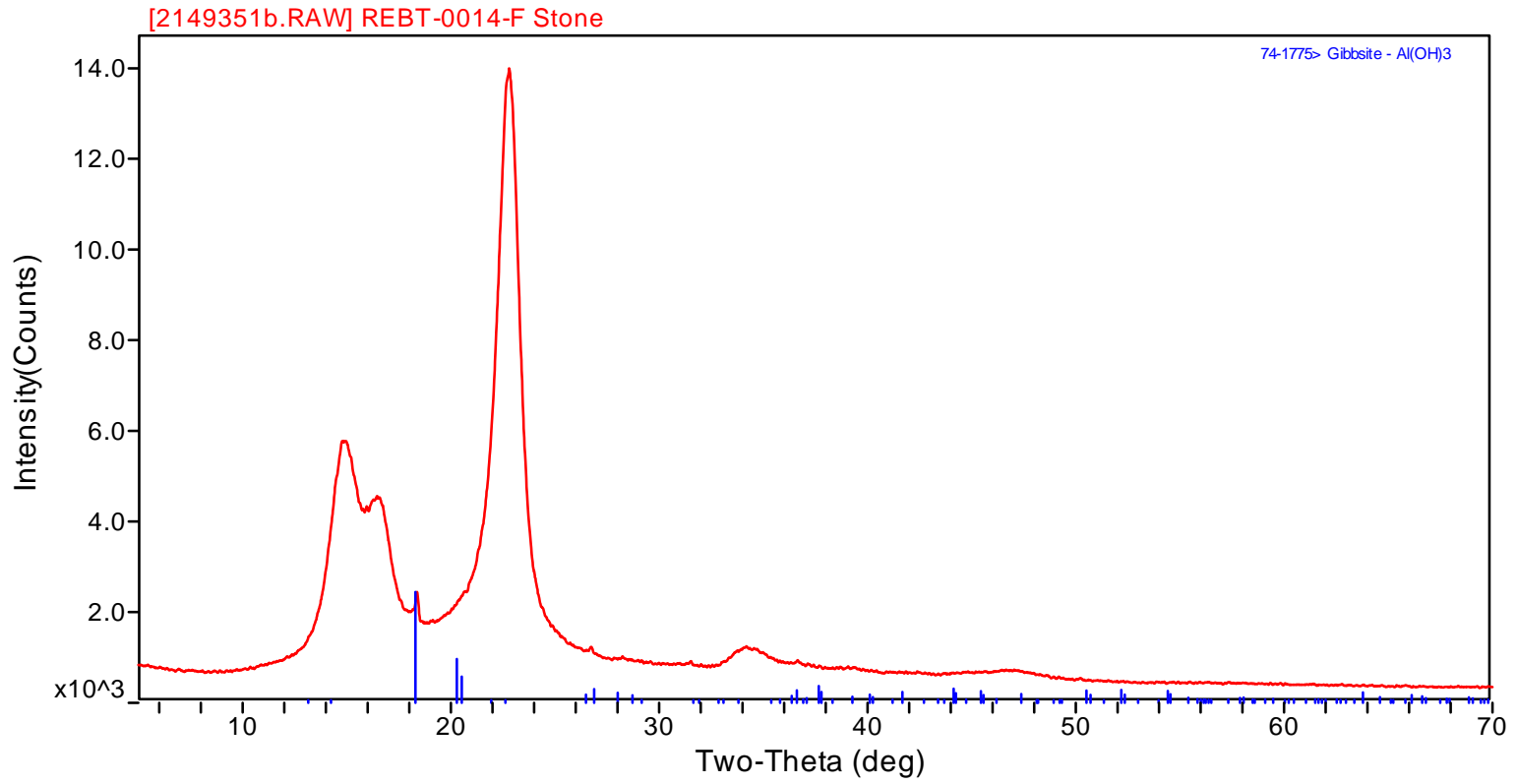

Figure D-11. Scenario 2 Concentrate XRD 


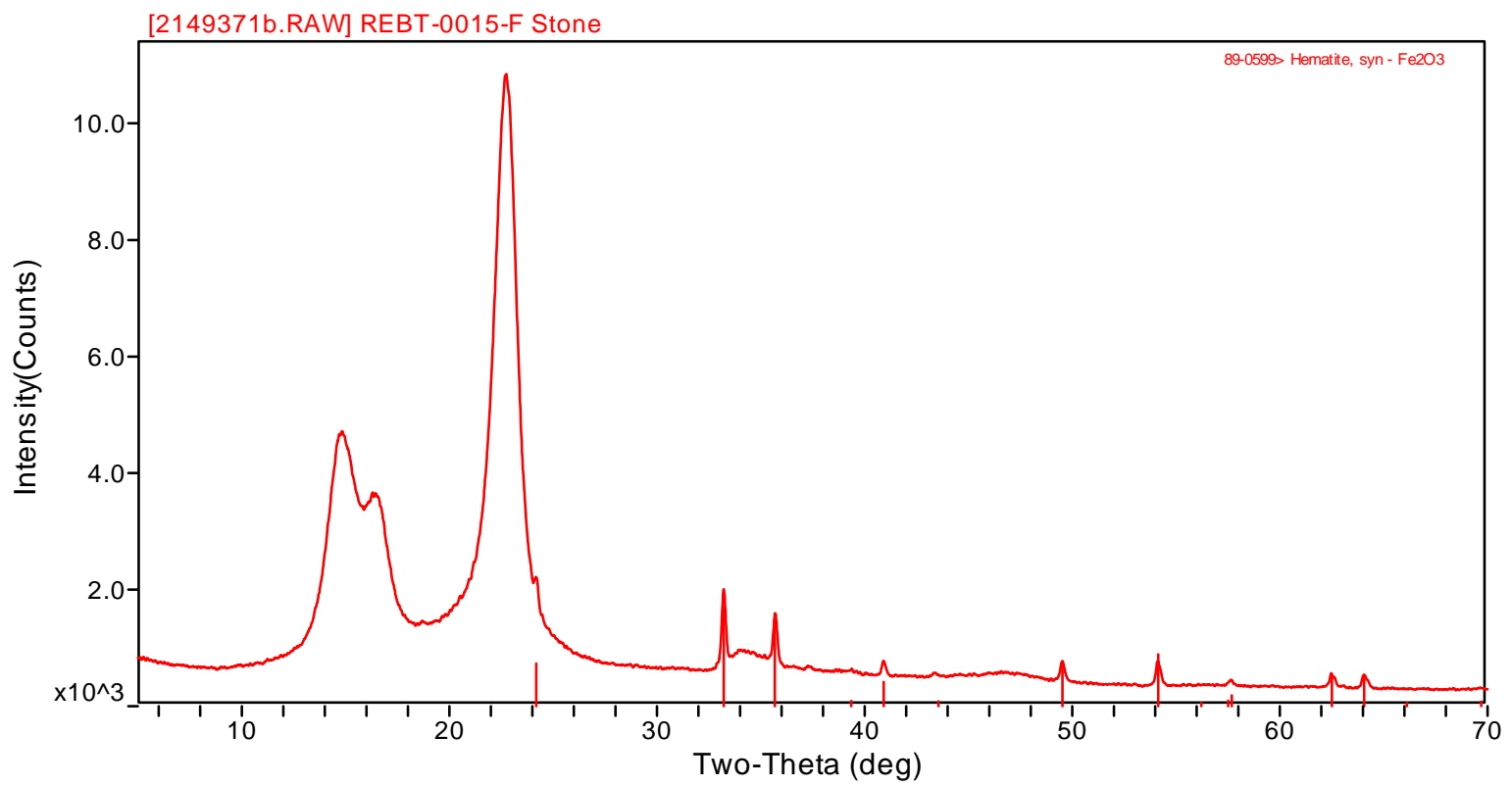

Figure D-12. Scenario 3 Feed XRD

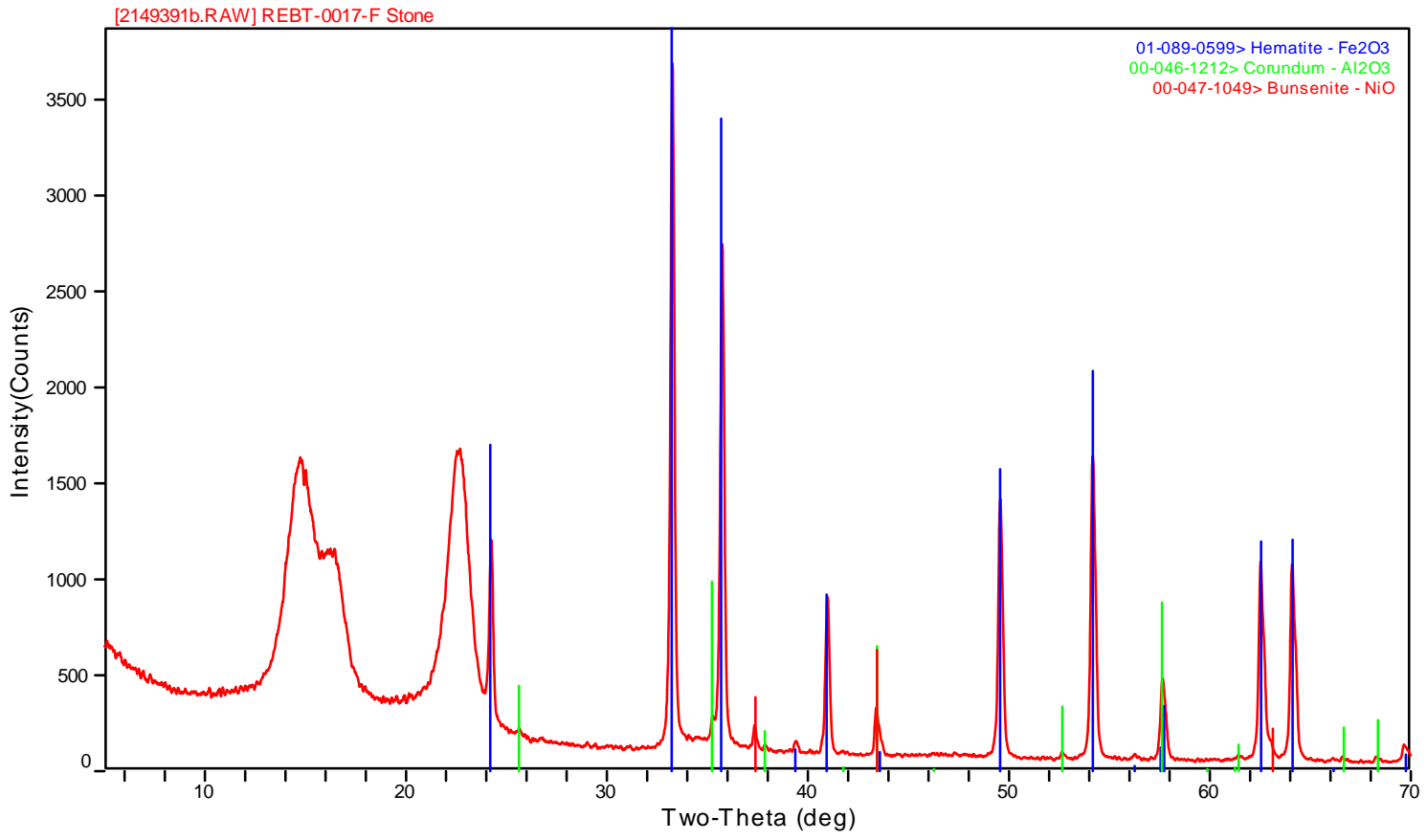

Figure D-13. Scenario 3 Concentrate XRD 
WSRC-TR-2005-00142

Revision 0

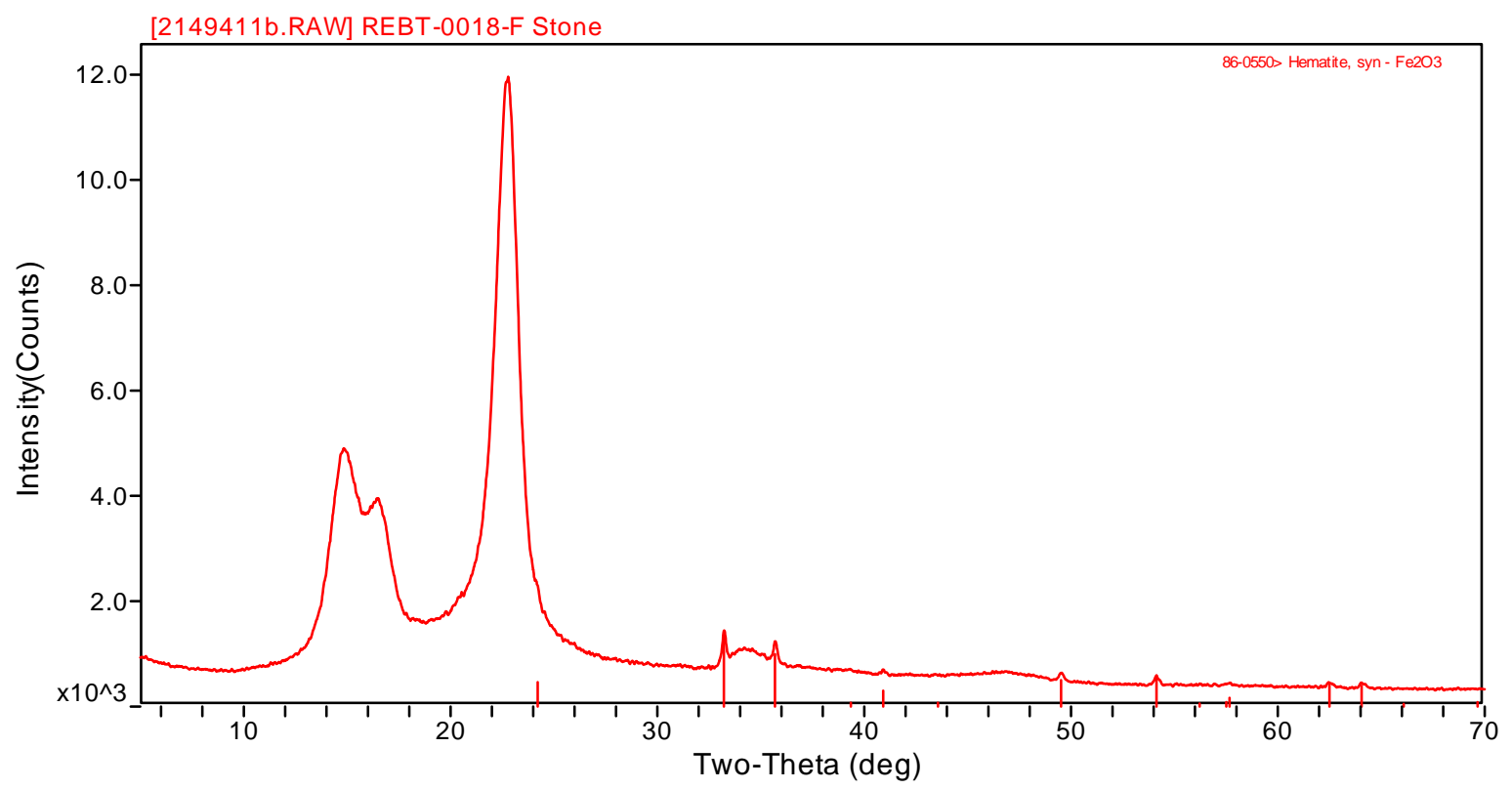

Figure D-14. Scenario 4 Feed XRD 


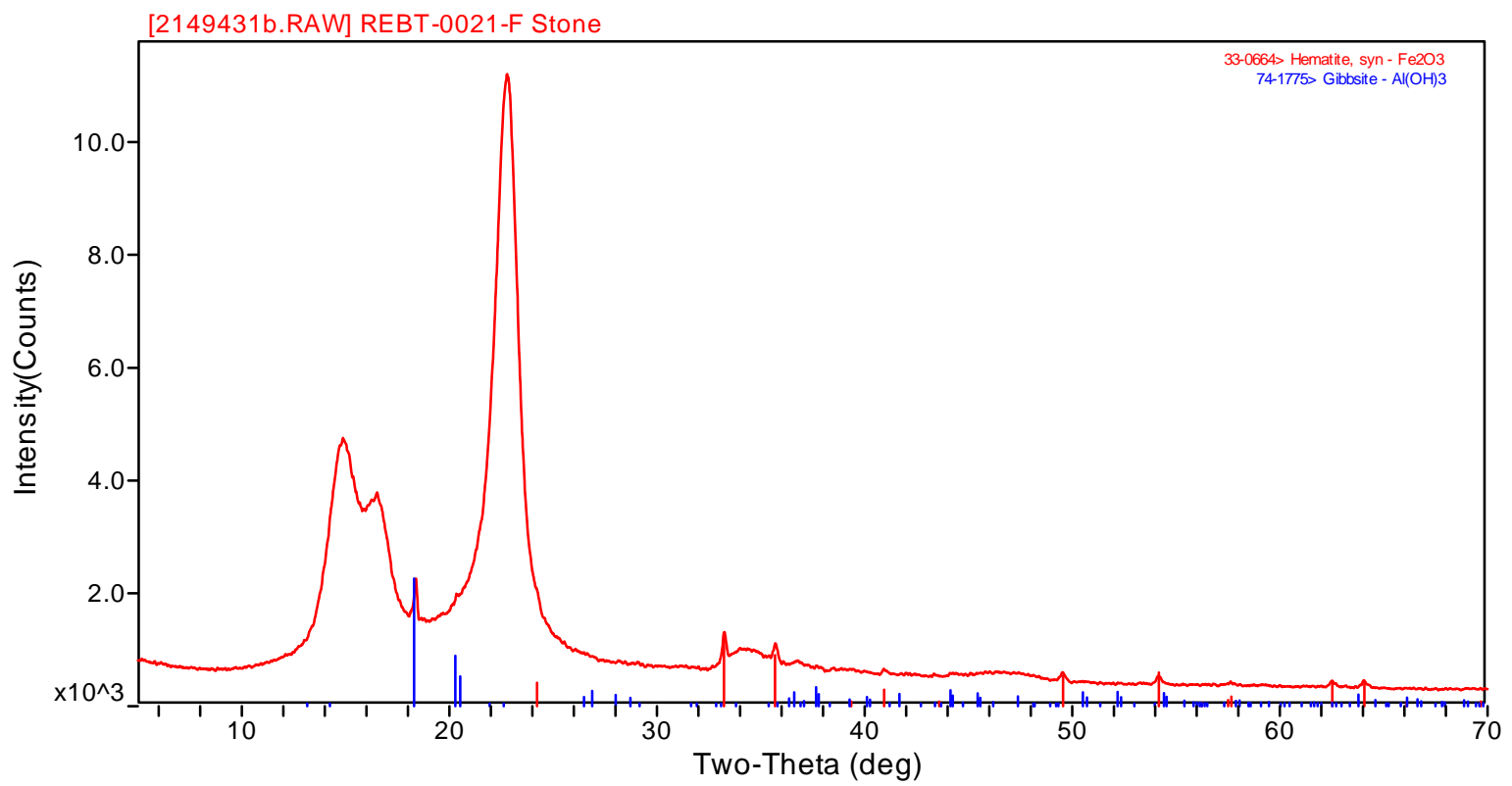

Figure D-15. Scenario 5 Feed XRD

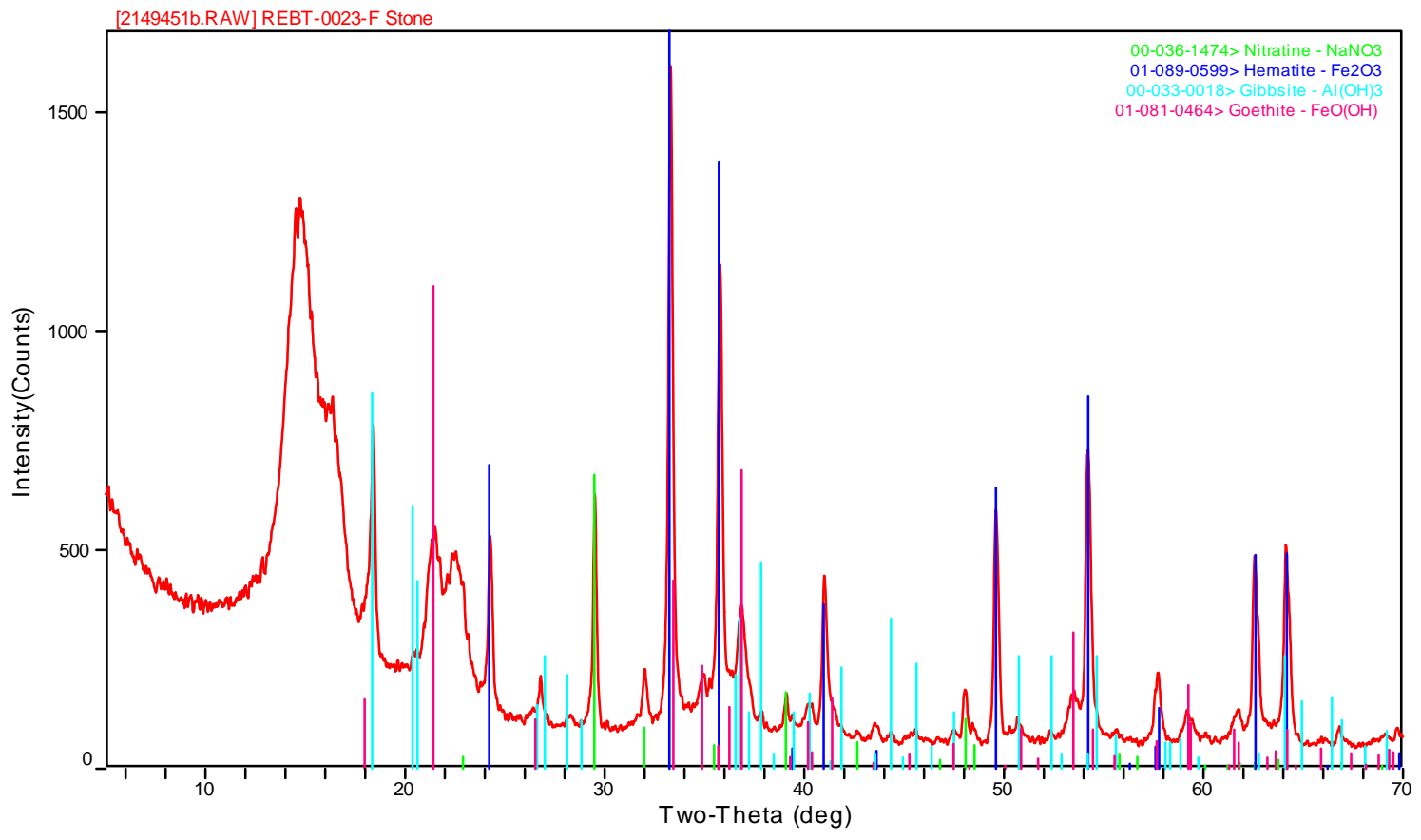

Figure D-16. Scenario 5 Concentrate XRD 
WSRC-TR-2005-00142

Revision 0

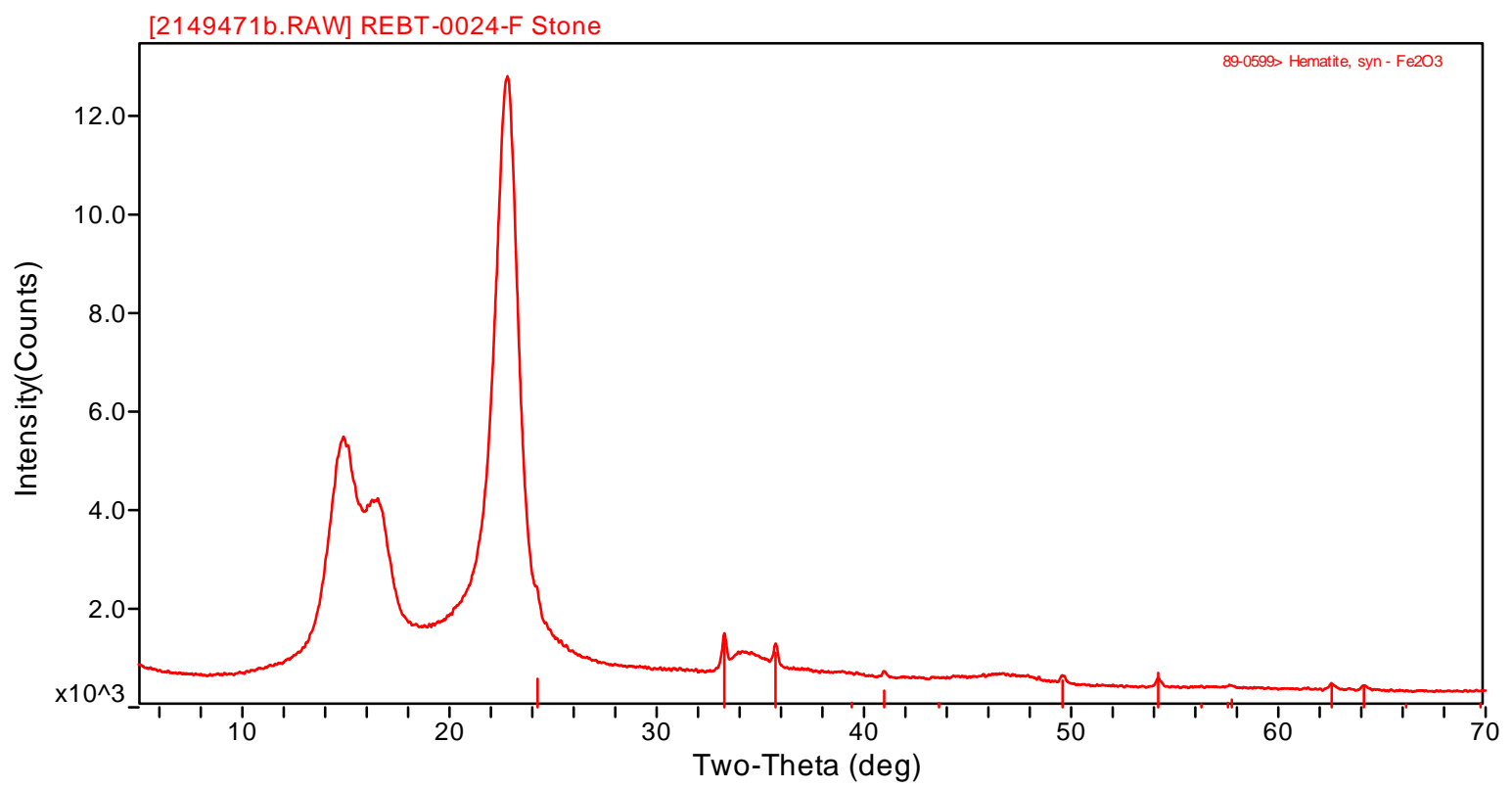

Figure D-17. Scenario 6 Feed XRD

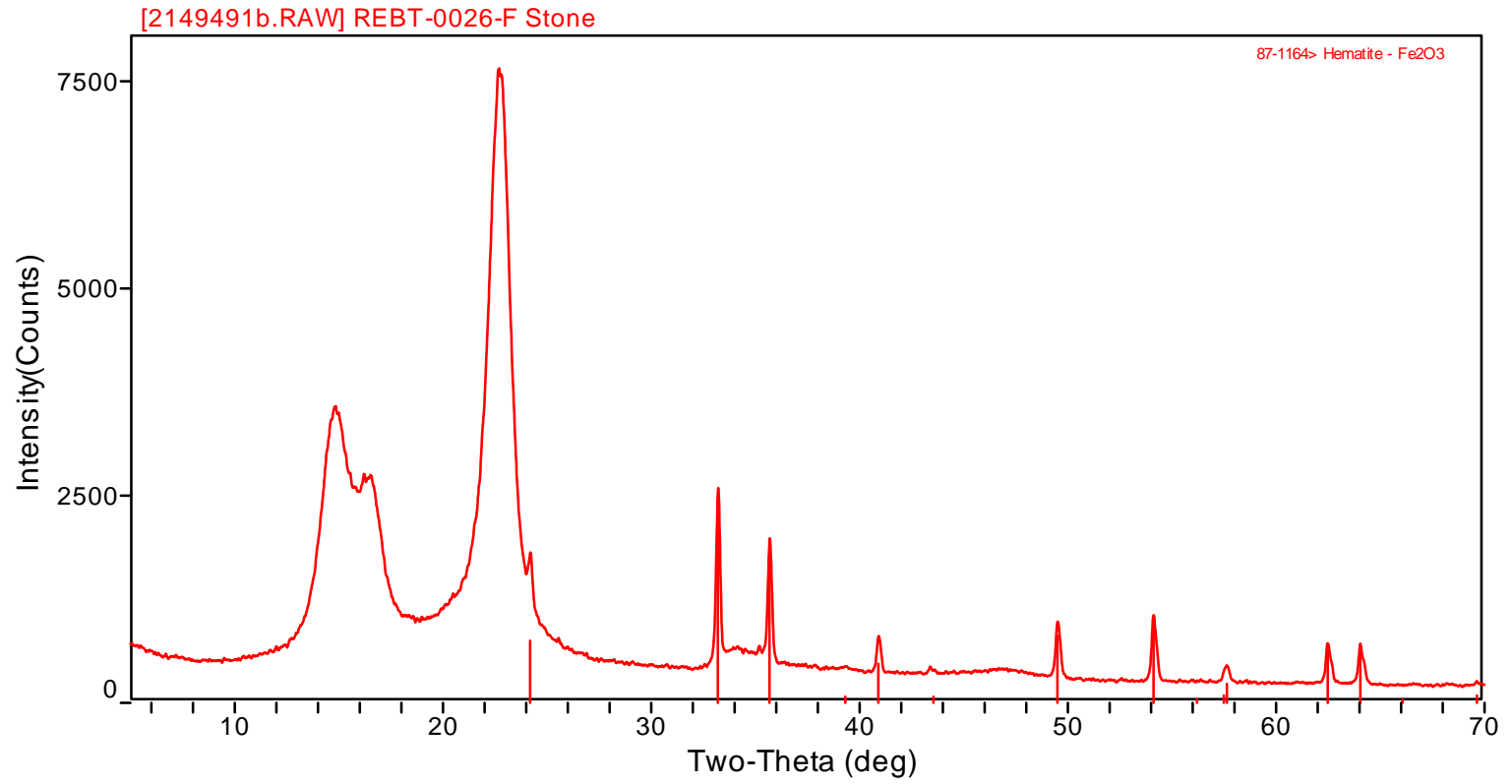

Figure D-18. Scenario 6 Concentrate XRD 


\section{APPENDIX E. CONDENSATE PH PROFILES}

Table E-1. Condensate pH Measurements

\begin{tabular}{|c|c|c|c|c|c|c|c|c|}
\hline $\begin{array}{c}\text { Bottle } \\
\#\end{array}$ & $\begin{array}{c}\text { Scenario } \\
1-1\end{array}$ & $\begin{array}{c}\text { Scenario } \\
1-2\end{array}$ & $\begin{array}{c}\text { Scenario } \\
1-3\end{array}$ & $\begin{array}{c}\text { Scenario } \\
2\end{array}$ & $\begin{array}{c}\text { Scenario } \\
3\end{array}$ & $\begin{array}{c}\text { Scenario } \\
4\end{array}$ & $\begin{array}{c}\text { Scenario } \\
5\end{array}$ & $\begin{array}{c}\text { Scenario } \\
6\end{array}$ \\
\hline & & & & & & & & \\
\hline 1 & 3.07 & 3.04 & 2.94 & 2.84 & 2.64 & 3.05 & 2.27 & 3.18 \\
\hline 2 & 2.86 & 2.88 & 2.85 & 2.71 & 2.97 & 2.74 & 2.12 & 3.15 \\
\hline 3 & 2.78 & 2.84 & 2.77 & 2.57 & 2.96 & 2.46 & 2.00 & 3.04 \\
\hline 4 & 2.66 & 2.80 & 2.69 & 2.43 & 2.95 & 2.29 & 2.02 & 2.70 \\
\hline 5 & 2.09 & 2.74 & 2.57 & 2.20 & 2.94 & 2.11 & 1.98 & 3.11 \\
\hline 6 & 2.15 & 2.65 & 2.54 & 2.07 & 2.94 & 1.95 & 1.99 & 3.13 \\
\hline 7 & 2.17 & 2.52 & 2.43 & 1.95 & 2.94 & n/a & n/a & 3.09 \\
\hline 8 & 2.01 & 2.37 & 2.31 & 2.16 & 2.94 & n/a & n/a & 3.00 \\
\hline 9 & 2.33 & n/a & n/a & n/a & n/a & n/a & n/a & 2.89 \\
\hline 10 & n/a & n/a & n/a & n/a & n/a & n/a & n/a & 2.93 \\
\hline 11 & n/a & n/a & n/a & n/a & n/a & n/a & n/a & 2.84 \\
\hline 12 & n/a & n/a & n/a & n/a & n/a & n/a & n/a & 2.86 \\
\hline 13 & n/a & n/a & n/a & n/a & n/a & n/a & n/a & 2.64 \\
\hline 14 & n/a & n/a & n/a & n/a & n/a & n/a & n/a & 2.62 \\
\hline 15 & n/a & n/a & n/a & n/a & n/a & n/a & n/a & 2.44 \\
\hline 16 & n/a & n/a & n/a & n/a & n/a & n/a & n/a & 2.60 \\
\hline
\end{tabular}

Condensate pH Profiles: Scenario 1

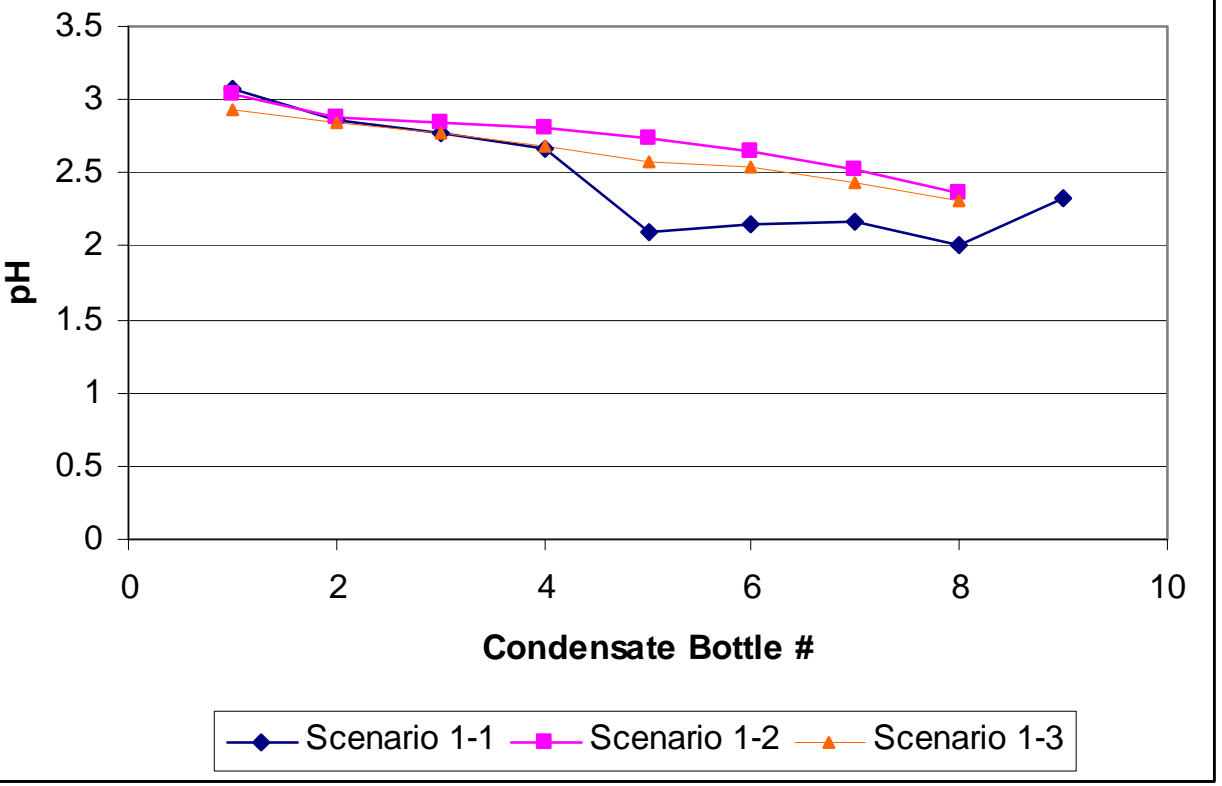

Figure E-1. $\mathrm{pH}$ profile for Scenario 1-1, 1-2, and 1-3 


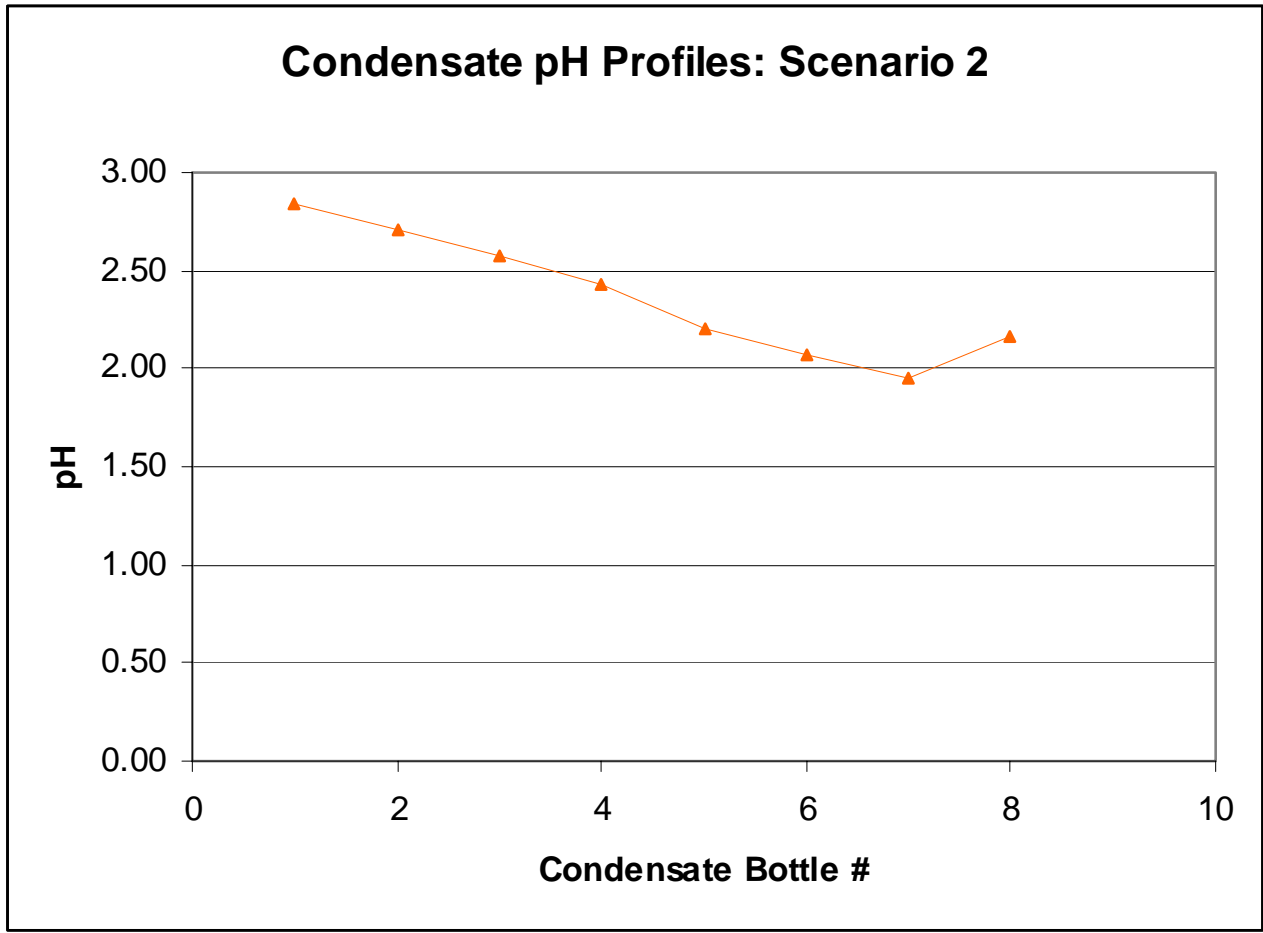

Figure E-2. pH profile for Scenario 2

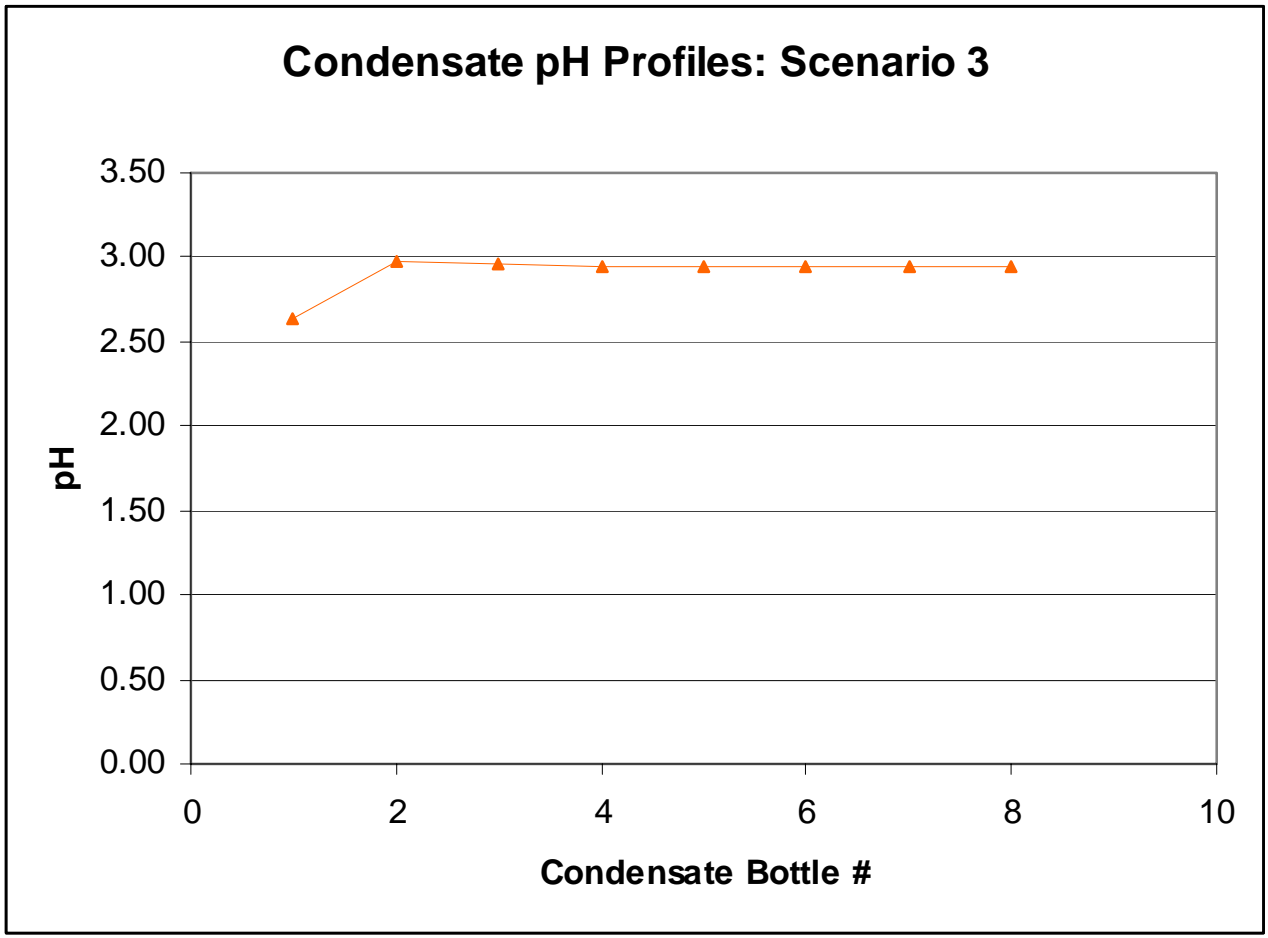

Figure E-3. pH profile for Scenario 3 


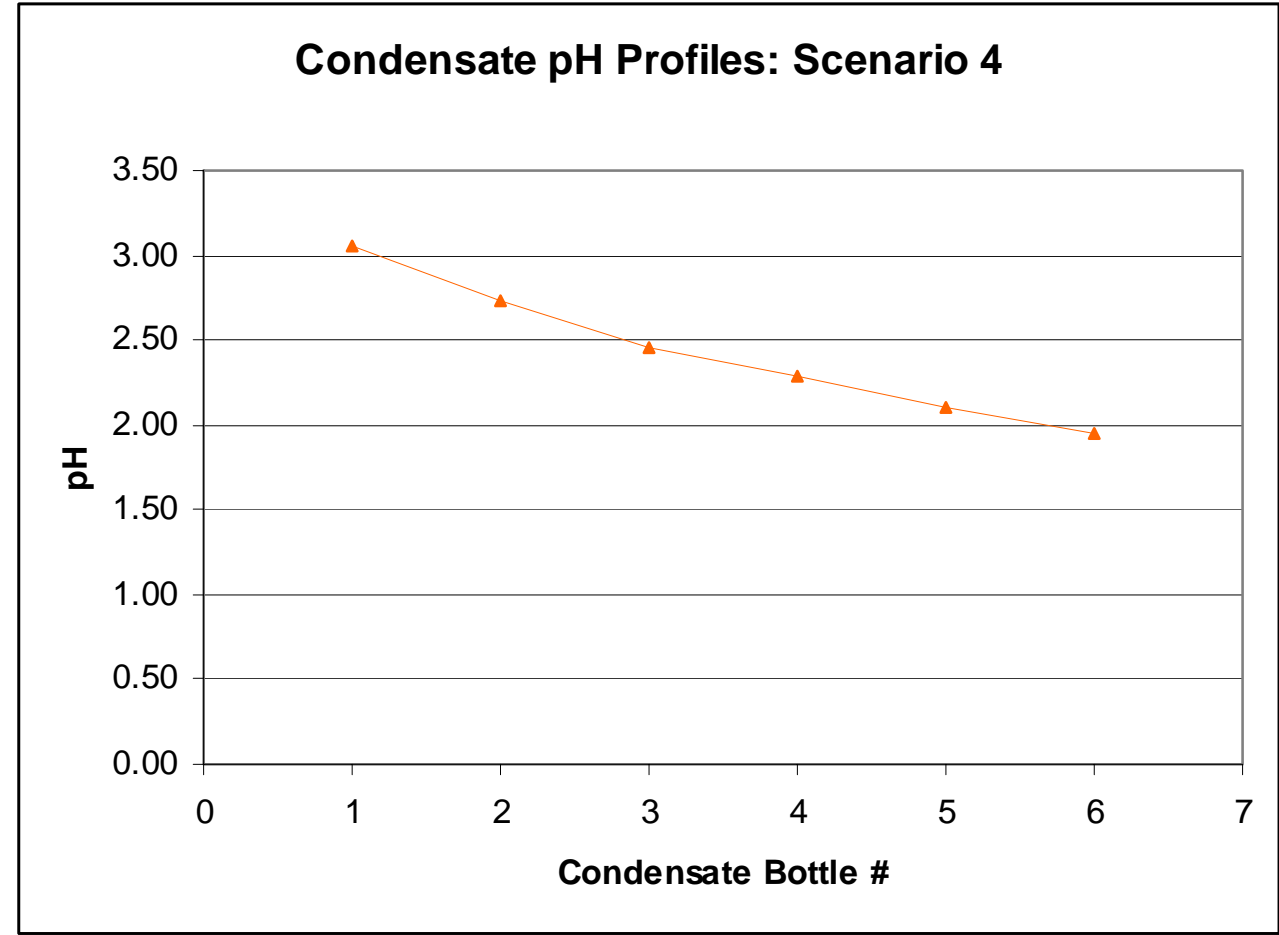

Figure E-4. pH profile for Scenario 4

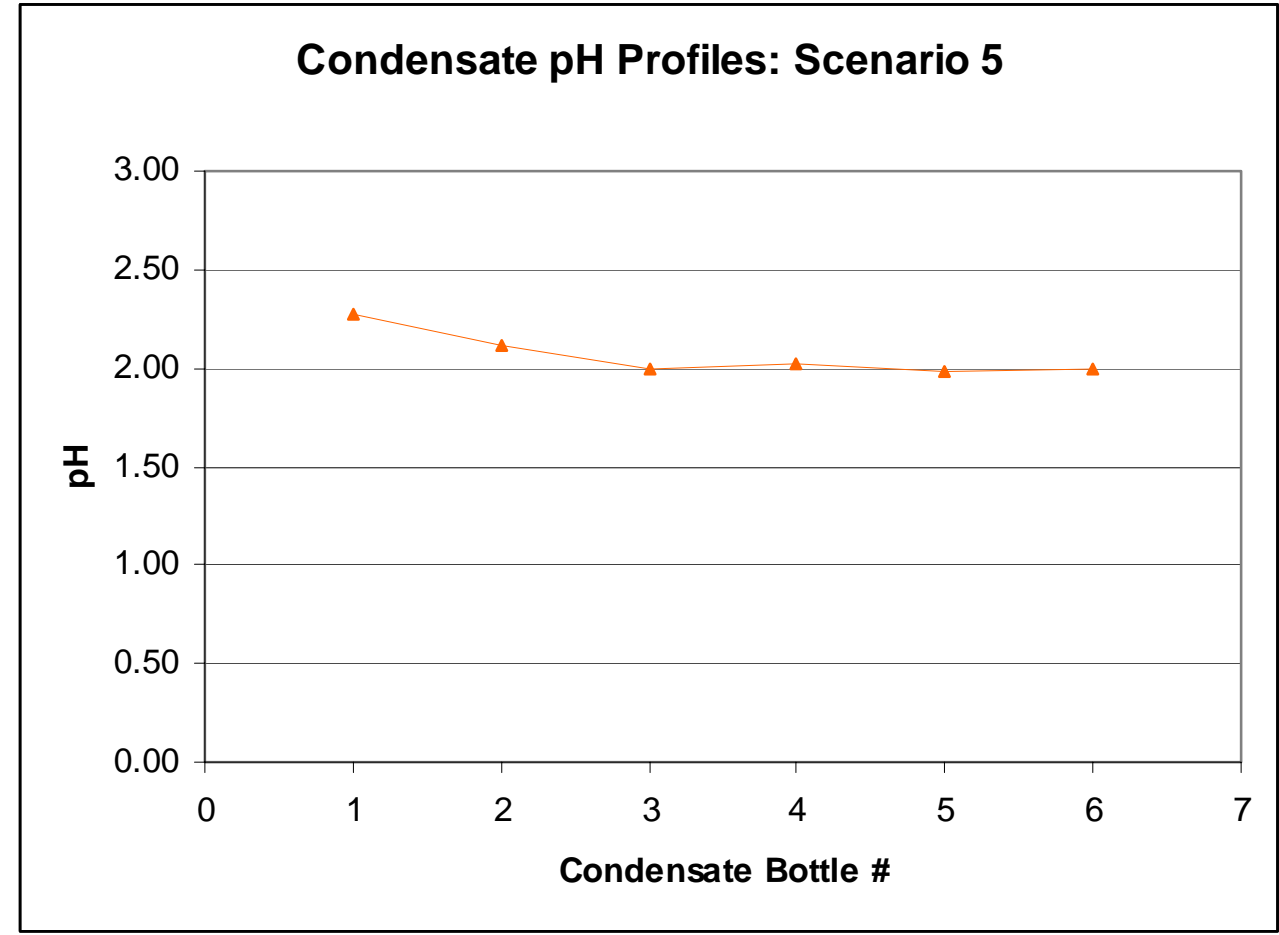

Figure E-5. pH profile for Scenario 5 


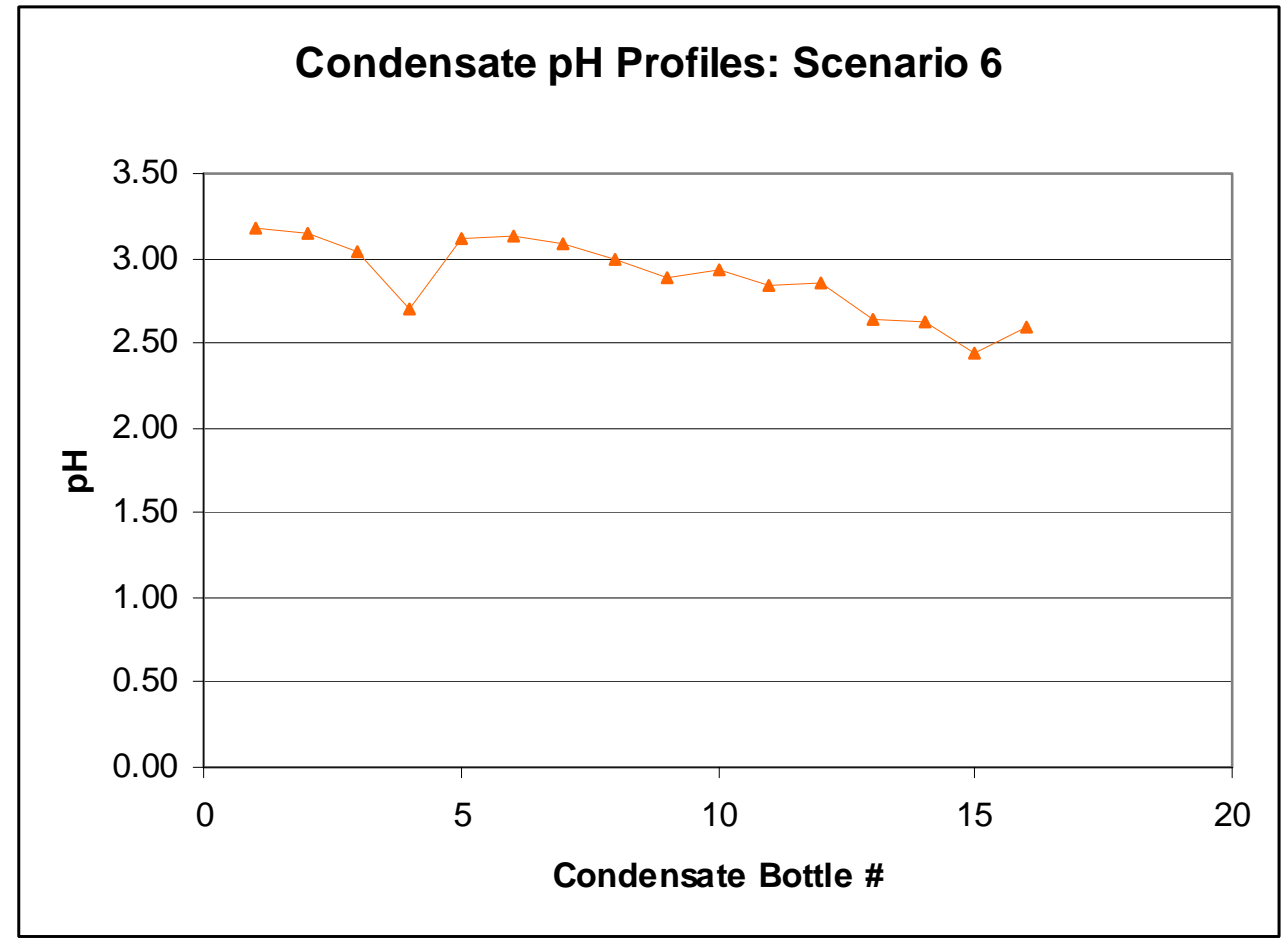

Figure E-6. pH profile for Scenario 6 
WSRC-TR-2005-00142

Revision 0

\section{APPENDIX F. DF TRENDING}

Table F-1. DF Factors for Recycle Evaporation

\begin{tabular}{|c|c|c|c|c|c|c|c|c|c|c|c|c|}
\hline & $\begin{array}{c}\text { Sample } \\
\text { Detection } \\
\text { Limit }\end{array}$ & $\begin{array}{c}\text { Scenario } \\
1-1 \\
\end{array}$ & $\begin{array}{c}\text { Scenario } \\
1-2 \\
\end{array}$ & $\begin{array}{c}\text { Scenario } \\
1-3 \\
\end{array}$ & $\begin{array}{c}\text { Scenario } \\
2 \\
\end{array}$ & $\begin{array}{c}\text { Scenario } \\
3 \\
\end{array}$ & $\begin{array}{c}\text { Scenario } \\
4 \\
\end{array}$ & $\begin{array}{c}\text { Scenario } \\
5 \\
\end{array}$ & $\begin{array}{c}\text { Scenario } \\
6 \\
\end{array}$ & Low & Average & High \\
\hline $\mathrm{Ag}$ & 0.1 & 0 & 0 & 0 & 0 & 0 & 0 & 4.15 & 0 & $\mathrm{~nm}$ & 4.15 & $\mathrm{~nm}$ \\
\hline $\mathrm{Al}$ & 0.1 & 100 & 40 & 40 & 154 & 5.07 & 229 & 2255 & 18 & 5 & 355 & 2255 \\
\hline $\mathrm{B}$ & & 12.85 & 2.01 & 1.16 & 15.33 & 16.61 & 5.62 & 22.46 & 1.93 & 1.2 & 10 & 22 \\
\hline $\mathrm{Ba}$ & 0.01 & 47.9 & 0 & 0 & 54.8 & 0 & 0 & 532 & 0 & 48 & 211 & 532 \\
\hline $\mathrm{Ca}$ & 0.01 & 110 & 1640 & 1620 & 359 & 2385 & 10600 & 2802 & 846 & 110 & 2545 & 10600 \\
\hline $\mathrm{Cr}$ & 0.12 & 0 & 0 & 0 & 0 & 0 & 0 & 3.45 & 0 & 0 & 0 & 3 \\
\hline $\mathrm{Cu}$ & 0.01 & 26.7 & 44.2 & 37.3 & 49.8 & 0.0 & 30.3 & 886.5 & 17.0 & 17 & 156 & 887 \\
\hline $\mathrm{Fe}$ & 0.04 & 26750 & 21025 & 21763 & 2663 & 32000 & 16313 & 46750 & 9838 & 2663 & 22138 & 46750 \\
\hline Gd & 0.03 & 0 & 0 & 0 & 0 & 0 & 0 & 151.5 & 0 & $n m$ & 152 & $n m$ \\
\hline $\mathrm{K}$ & & 22.2 & 11.1 & 11.0 & 12.7 & 12.3 & 154.9 & 74.8 & 4.5 & 4 & 38 & 155 \\
\hline $\mathrm{Li}$ & 1 & 0 & 0 & 0 & 0 & 0 & 0 & 9.0 & 0 & $n m$ & 9 & $n m$ \\
\hline $\mathrm{Mg}$ & 0.01 & 3115 & 3180 & 3150 & 1010 & 5550 & 5215 & 21800 & 1535 & 1010 & 5569 & 21800 \\
\hline $\mathrm{Mn}$ & 0.01 & 6215 & 6335 & 6400 & 1950 & 12150 & 4545 & 6963 & 3235 & 1950 & 5974 & 12150 \\
\hline Mo & & 2.5 & 23.7 & 14.8 & 14.9 & 23.2 & 44.1 & 12.5 & 22.8 & 2 & 20 & 44 \\
\hline $\mathrm{Na}$ & 1 & 148 & 323 & 222 & 61.2 & 2065 & 15806 & 1215 & 173 & 61 & 2502 & 15806 \\
\hline $\mathrm{Ni}$ & 0.017 & 1088 & 862 & 797 & 210 & 1826 & 785 & 3912 & 334 & 210 & 1227 & 3912 \\
\hline $\mathrm{P}$ & 0.26 & 0 & 0 & 0 & 1.39 & 0 & 0 & 10.9 & 0 & 1 & $n m$ & 11 \\
\hline $\mathrm{Pb}$ & 0.02 & 0 & 0 & 0 & 0 & 0 & 0 & 244 & 0 & $n m$ & 244 & $n m$ \\
\hline $\mathrm{S}$ & 0.1 & 99 & 102 & 100 & 236 & 196 & 88 & 301 & 52 & 52 & 147 & 301 \\
\hline $\mathrm{Si}$ & & 0.074 & 1.162 & 1.176 & 0.052 & 21.361 & 6.275 & 32.829 & 4.421 & 0.05 & 8 & 33 \\
\hline $\mathrm{Ti}$ & 0.01 & 0 & 0 & 0 & 0 & 0 & 0 & 61 & 0 & $n m$ & 61 & $n m$ \\
\hline $\mathrm{Zn}$ & 0.01 & 13.4 & 0 & 0 & 47 & 0 & 0 & 1540 & 0 & 13 & 533 & 1540 \\
\hline $\mathrm{Zr}$ & 0.01 & 0 & 0 & 0 & 0 & 0 & 67 & 30 & 0 & 30 & $n m$ & 67 \\
\hline NO3 & 100 & 9.1 & 12.9 & 9.2 & 7.8 & 16.1 & 28.5 & 7.1 & 11.0 & 7 & 13 & 29 \\
\hline $\mathrm{SO} 4$ & 100 & 4.87 & 0.91 & 0.87 & 1.66 & 13 & 1.21 & 7.91 & 1.20 & 0.9 & 4 & 13 \\
\hline $\mathrm{HCO} 2$ & 100 & 1.05 & 0 & 0 & 0.80 & 0 & 0 & 1.39 & 0 & 0.80 & 1.08 & 1.39 \\
\hline $\mathrm{Hg}$ & 2.5 & 1.0 & 12.6 & 2.6 & 8.5 & 63.6 & 3.3 & 5.4 & 3.4 & 1.0 & 13 & 64 \\
\hline
\end{tabular}

NOTE: Italics represent DF's calculated based on the detection limits in the condensate. 


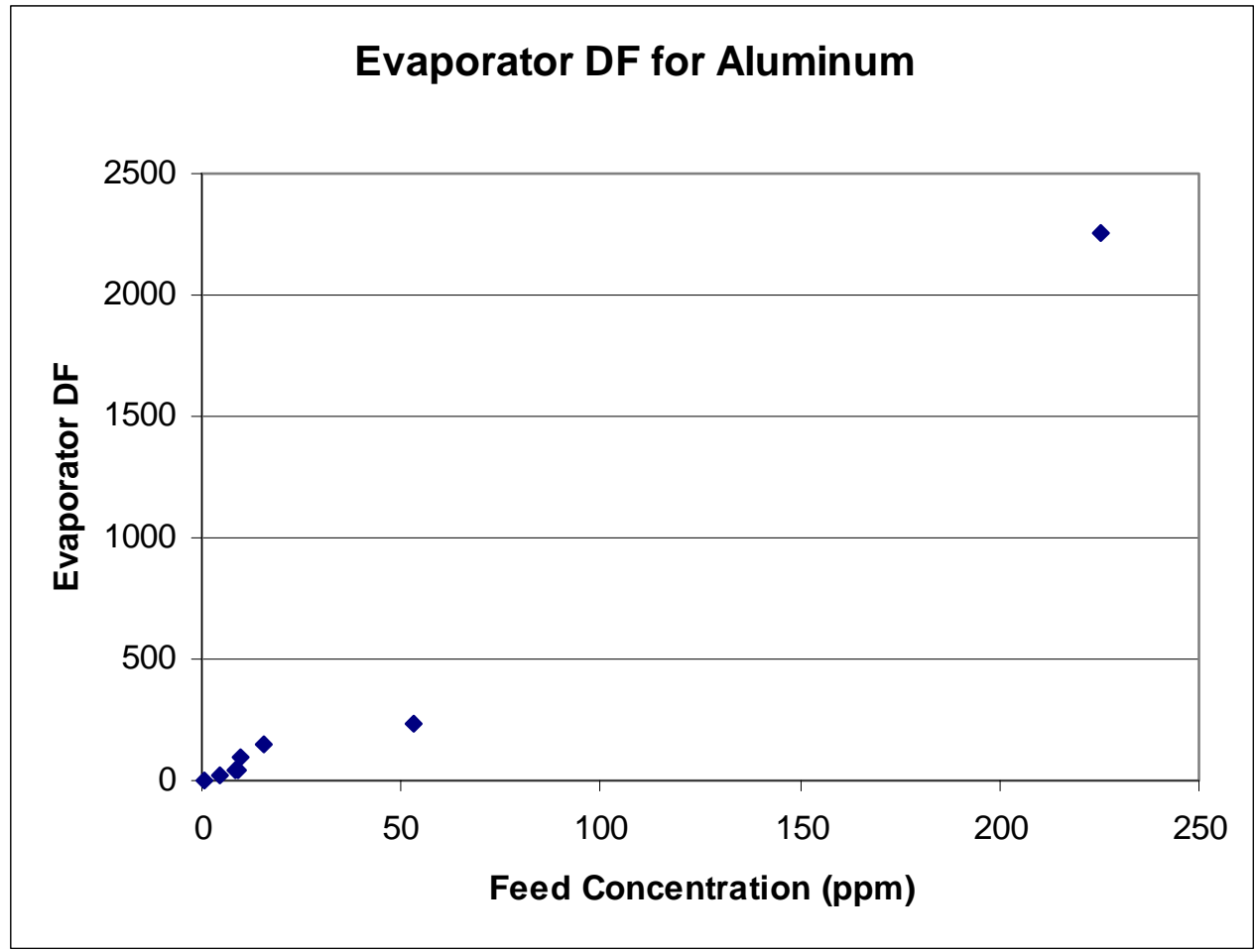

Figure F-1. DF Trend for Aluminum

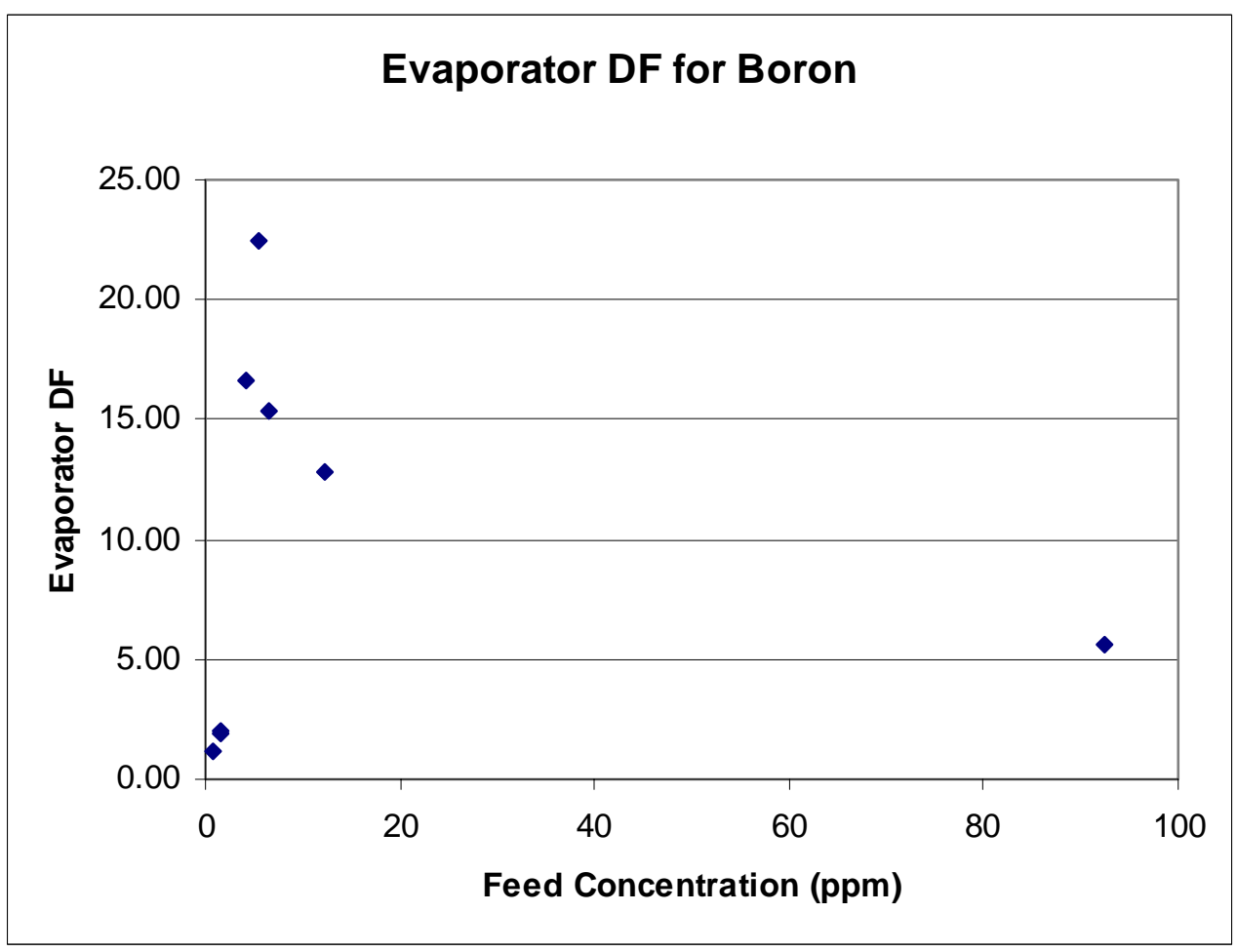

Figure F-2. DF Trend for Boron 


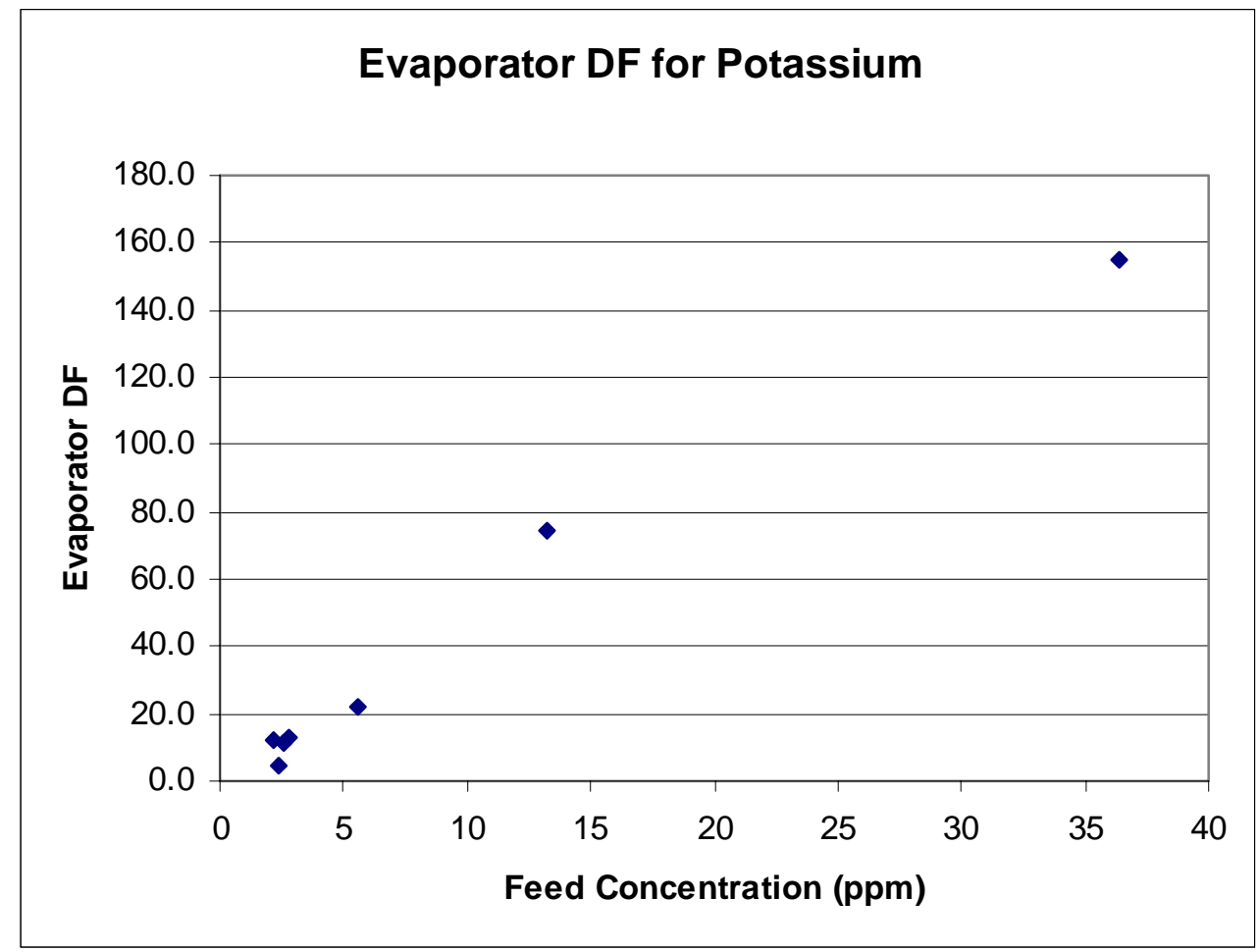

Figure F-3. DF Trend for Potassium

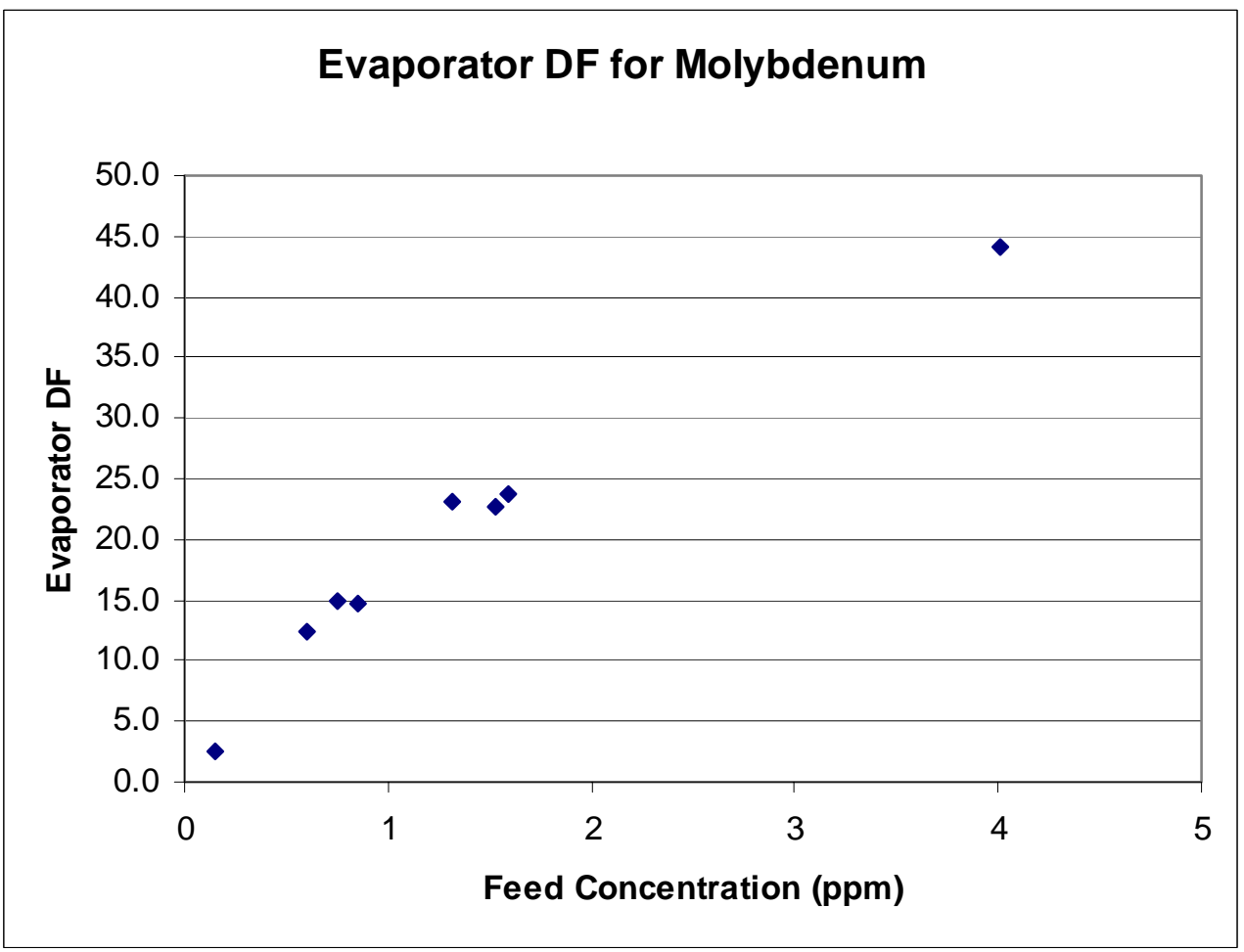

Figure F-4. DF Trend for Molybdenum 


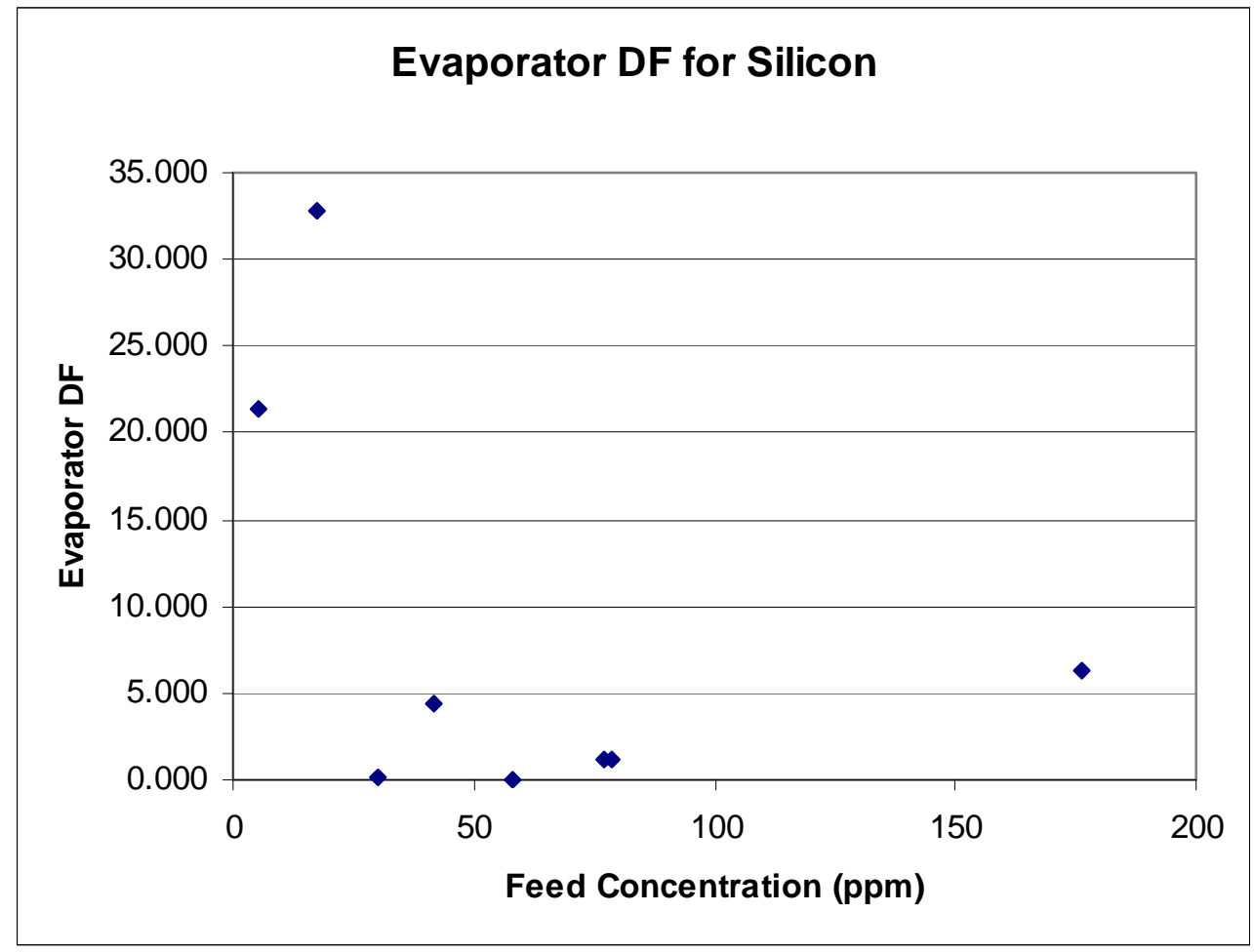

Figure F-5. DF Trend for Silicon

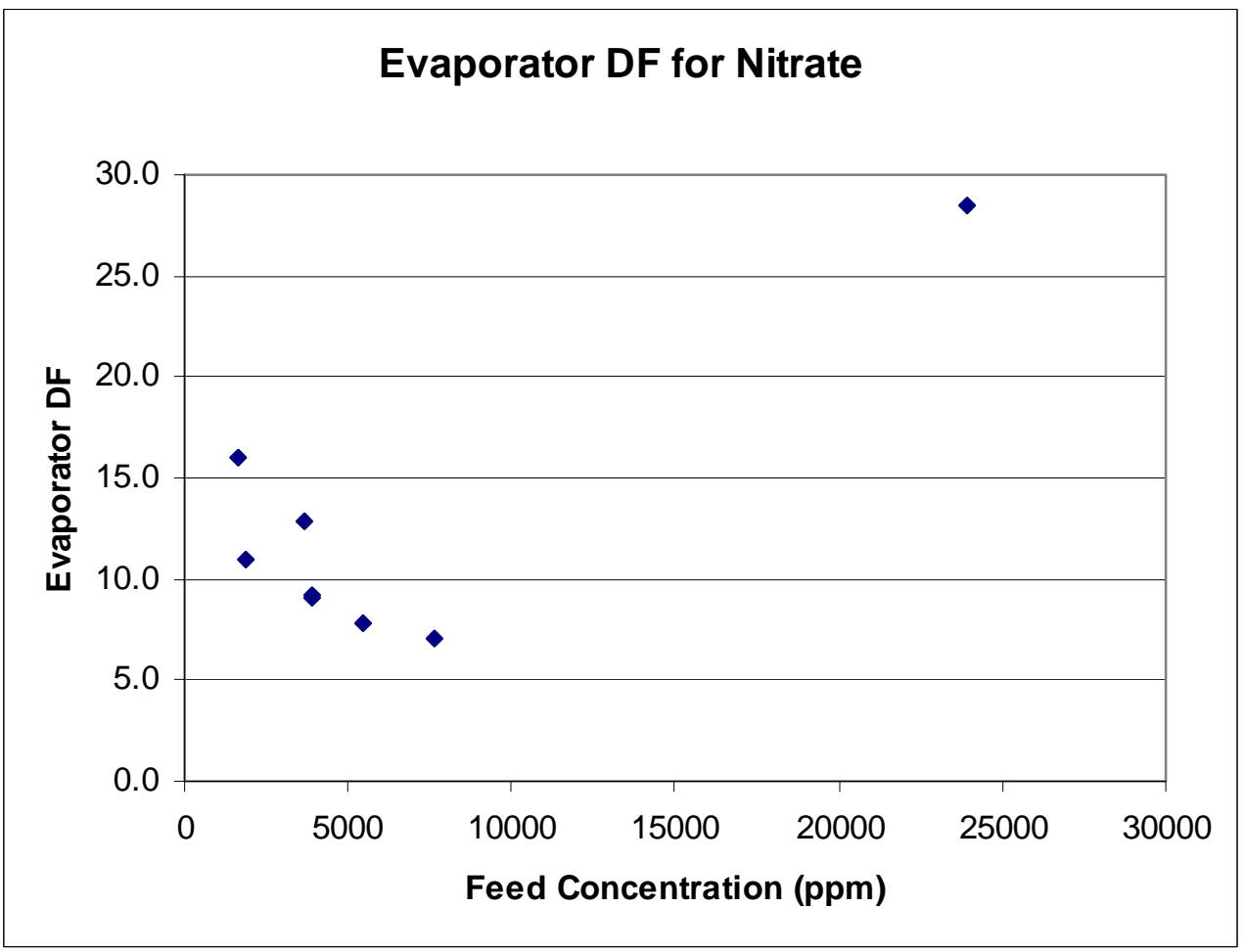

Figure F-6. DF Trend for Nitrate 
WSRC-TR-2005-00142

Revision 0

This page intentionally left blank. 


\section{Distribution:}

E. W. Holtzscheiter, 773-A

D. A. Crowley, 999-W

S. L. Marra, 999-W

T. B. Calloway, 999-W

N. E. Bibler, 773-A

C.M. Jantzen, 773-A

J. R. Harbour, 773-42A

G. G. Wicks, 773-A

W. E. Daniel, 999-W

T. L. Fellinger, 773-A

C.C. Herman, 773-42A

D. K. Peeler, 999-W

M. E. Smith, 773-42A

D. C. Koopman, 773-42A

T. B. Edwards, 773-42A

D. T. Herman, 773-A

M. S. Miller, 704-S

J. E. Occhipinti, 704-S

R. M. Hoeppel, 704-27S

H. H. Elder, 703-H

J. F. Iaukea, 704-30S

J. W. Ray, 704-S

F. A. Washburn, 704-27S

W. B. Van-Pelt, 704-S

S. G. Phillips, 704-27S

A. V. Staub, 704-27S 